\title{
U.S.-Russian Experts NATO Collaborative Research Grant Exchange Visit Meetings on Excess Weapons Pu Ceramics Formulations and Characterizations
}

\author{
L. J. Jardine \\ G. A. Armantrout \\ W. L. Bourcier \\ W. A. Brummond \\ B. B. Ebbinghaus \\ H. F. Shaw
}

R. A. Van Konynenburg

P. Zhao

November 24-26, 1997

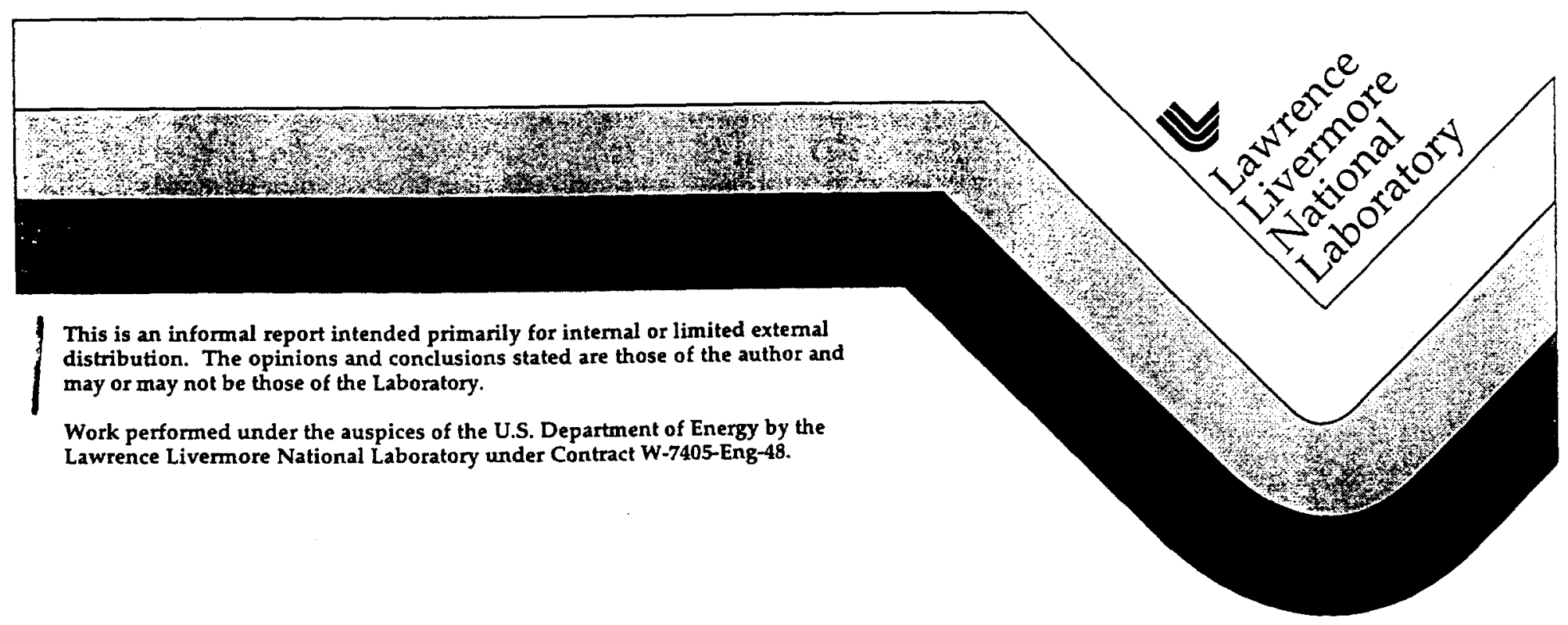




\section{DISCLAIMER}

This document was prepared as an account of work sponsored by an agency of the United States Government. Neither the United States Government nor the University of California nor any of their employees, makes any warranty, express or implied, or assumes any legal liability or responsibility for the accuracy, completeness, or usefulness of any information, apparatus, product, or process disclosed, or represents that its use would not infringe privately owned rights. Reference herein to any specific commercial product, process, or service by trade name, trademark, manufacturer, or otherwise, does not necessarily constitute or imply its endorsement, recommendation, or favoring by the United States Government or the University of California. The views and opinions of authors expressed herein do not necessarily state or reflect those of the United States Government or the University of California, and shall not be used for advertising or product endorsement purposes.

This report has been reproduced directly from the best available copy.

Available to DOE and DOE contractors from the Office of Scientific and Technical Information

P.O. Box 62, Oak Ridge, TN 37831

Prices available from (615) 576-8401, FTS 626-8401

Available to the public from the

National Technical Information Service

U.S. Department of Commerce

5285 Port Royal Rd.,

Springfield, VA 22161 


\section{Final Agenda}

\section{U.S.-Russian Experts NATO Exchange Visit Meetings on Excess Weapons Pu Ceramics Formulations and Characterizations \\ November 24-26, 1997}

Saturday:

November 22

Monday

November 24:

9:15 a.m.

10:00 a.m.

11:00 a.m.

12:00 p.m.

1:00 p.m.

2:00 p.m.

4:00 p.m.

Tuesday

November 25:

8:30 a.m.

8:45 a.m.

9:00 a.m.

9:45 a.m.

10:15 a.m.

10:30 a.m.

11:15 a.m.
Fly from St. Petersburg to San Erancisco

Badging at LLNL West Badge Office

Trailer 1677 - Room 1085

Welcome and Introductions

L. Jardine

U.S. Pu Disposition Program Overview

H. Shaw

Invited Lunch

Pu Building Training Film

D. Johnstone

Pu Building Tour, Bldg. 332

B. Ebbinghaus

Cold Ceramics Laboratory Tour, Bldg. 241

R. Vankonynenburg

P. Curtis

B. Brummond

Bldg. 151 Tour - Pu Leaching

W. Bourcier

Plutonium Ceramics Meetings

\section{Trailer 1677 - Room 1085}

Welcome, Introductions and Objectives

L. Jardine

\section{U.S.Pu Disposition Ceramics Activities}

R. Vankonynenburg - Chairman

Formulations and Fabrication of Small Pellets

R. Vankonynenburg

Engineering Scale-up of Fabrication Process

G. Armantrout

Break

Dissolution Testing

W. Bourcier

Summary of Technical Issues, Problems and Needs

B. Ebbinghaus

- Effects of Impurities

- Radiation Damage Effect 


\section{Final Agenda}

\section{U.S.-Russian Experts NATO Exchange Visit Meetings on Excess Weapons Pu Ceramics Formulations and Characterizations}

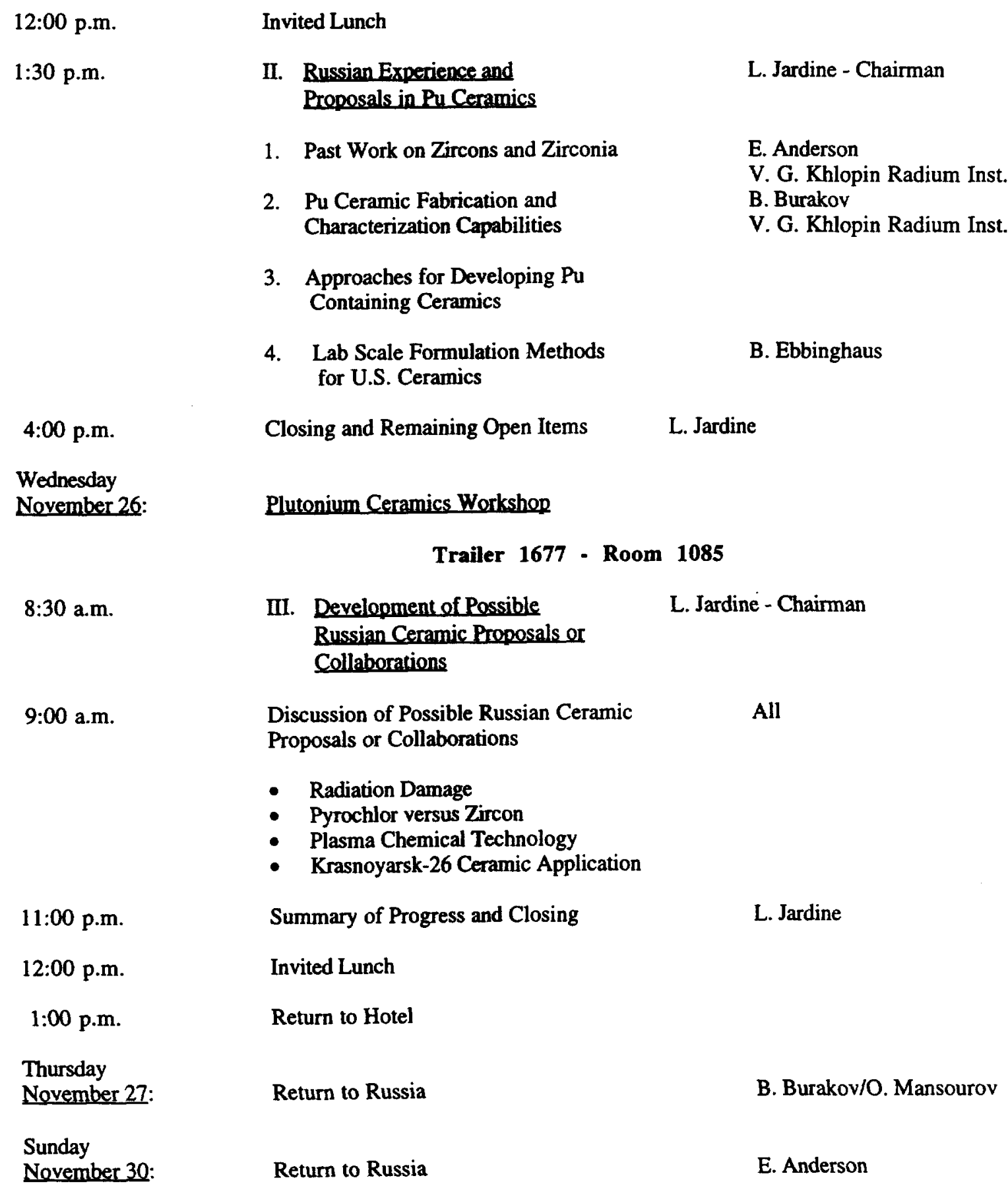


Meeting Attendees

L. J. Jardine

E. B. Anderson

B. E. Burakov

O. A. Mansourov

L. M. MacLean

G. A. Armantrout

V. V. Romanovski

C. W. Ma

B. B. Ebbinghaus

D. P. Johnstone

R. Vankonynenburg

H. F. Shaw

L. W. Gray

A. MacFarlane

P. Zhao

W. L. Bourcier

J. S. Choi

C. Glushkoff
Organization

LLNL

V. G. Khlopin Radium Inst.

V. G. Khlopin Radium Inst.

A. A. Bochvar Institute $x$

LLNL

LLNL

LLNL

LLNL

LLNL

LLNL

LLNL.

LLNL

LLNL

CISAC, Stanford

LLNL

LLNL

LLNL

Interpreter (self-employed) $\mathrm{x}$
Dates

$11 / 24 \quad 11 / 25 \quad 11 / 26$

$\begin{array}{lll}\mathbf{x} & \mathbf{x} & \mathbf{x} \\ \mathbf{x} & \mathbf{x} & \mathbf{x} \\ \mathbf{x} & \mathbf{x} & \mathbf{x} \\ \mathbf{x} & \mathbf{x} & \mathbf{x}\end{array}$

$x$

$x \quad x$

$\mathbf{x}$

$\mathbf{x}$

$x$

$\mathrm{x} \quad \mathrm{x}$

$\mathrm{x}$

$x$

$\mathbf{X}$

$\mathrm{x}$

$x$

$x$

$x$

x

LJJ98007/ps 
NATO Meeting

November 24-26, 1997

\section{Name}

1. Leslie Jardine

2. Lee MacLean

3. Guy Armantrout

4. Vadim Romanovski

5. Chin Ma

6. Rich Vankonynenburg

7. Henry Shaw

8. Bill Bourcier

9. Leonard Gray

10. Allison MacFarlane

11. Bart Ebbinghaus

12. Pihong Zhao
Organization

LLNL

LLNL

LLNL

LLNL

LLNL

LLNL

LLNL

LLNL

LLNL

CISAC/Stanford

LLNL

LLNL
Title or Position

Russian Project Manager

Deputy Program Leader - PPAC

Form, Process \& Equipment R\&D Manager

Post Doctoral Fellow

Senior Scientist

Engineer - Ceramic Formulation

Characterization Qualification R\&D Manager

Chemist

Chief Scientist

Science Fellow, Assistant Professor

Chemist

Chemist 


\section{Overview of the U.S. Fissile}

Materials Disposition Program: Plutonium Immobilization

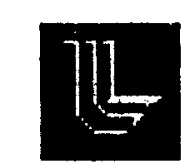

Henry F. Shaw, LLNL

Nov. 24, 1997

U.S. - Russian Experts NATO

Exchange Meeting 


\section{Fissile Material Disposition Problem}

- What to do with fissile materials surplus to national security requirements?

- Approximately 174 metric tons of highly enriched uranium (HEU)

$\star$ - Approximately 50 metric tons of plutonium 


\section{Candidate Plutonium Materials for Immobilization}

Pu Mass, MT

Clean metal (incl. pits)

32.8

Impure metal

2.4

Plutonium alloys

1.0

Clean oxides

1.7

Impure oxides

6.4

U/Pu oxides

0.9

Alloy reactor fuel

3.5

Oxide reactor fuel

1.3

Total plutonium

50.0

Total uranium

16.6 


\section{Pu Disposition: Dual Track Approach}

Combination of Immobilization and Reactor Irradiation

- Pure Pu to Reactor and impure Pu to Immobilization, or

- 50 MT to Immobilization

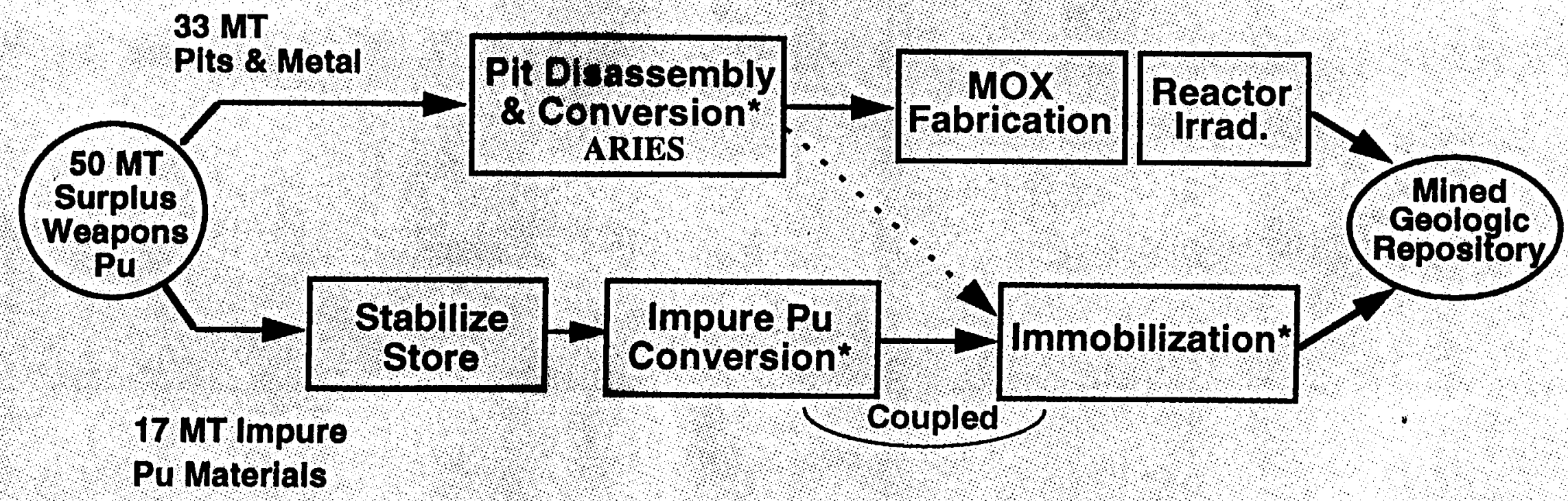




\section{Immobilization Focus in FY 97}

$\sqrt{ }$ R \& D data and technical evaluation of glass and ceramic technologies for immobilization form selection

- Can-in-canister versus homogeneous configuration

- Glass versus crystalline ceramic plutonium form

$\sqrt{ }$ Preliminary definition/characterization of impure Pu feed materials

- Preconceptual engineering study and data development for EIS 


\section{Current Immobilization Project Organization}

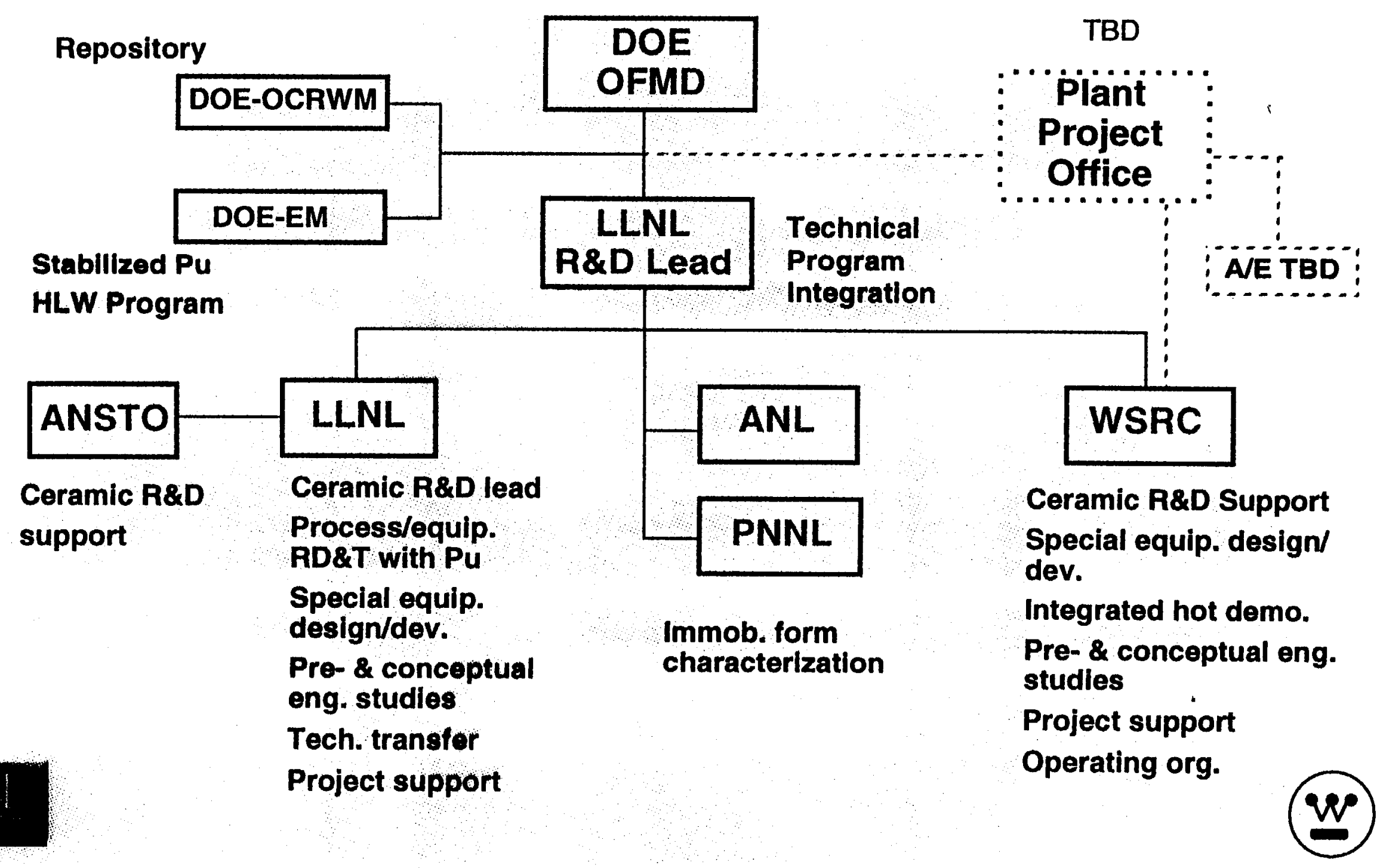




\section{Can-ın-Canister Immobilization Approach}

Full-scale test of concept during DWPF cold testing demonstrated viability of Can-in-canister approach

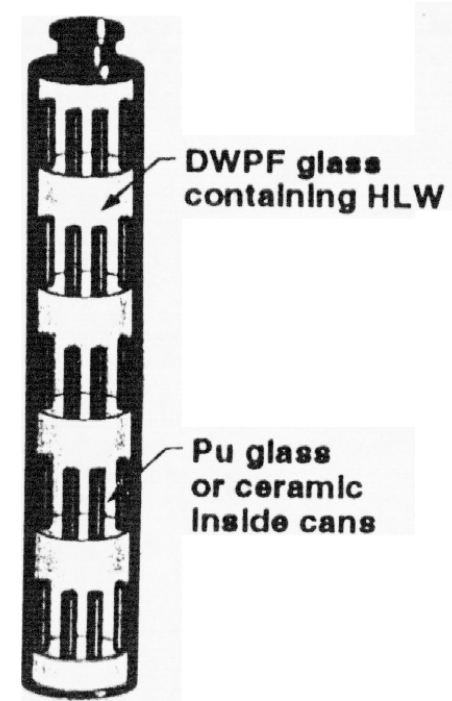

Plutonium heterogenoously distributéd (can in canister)
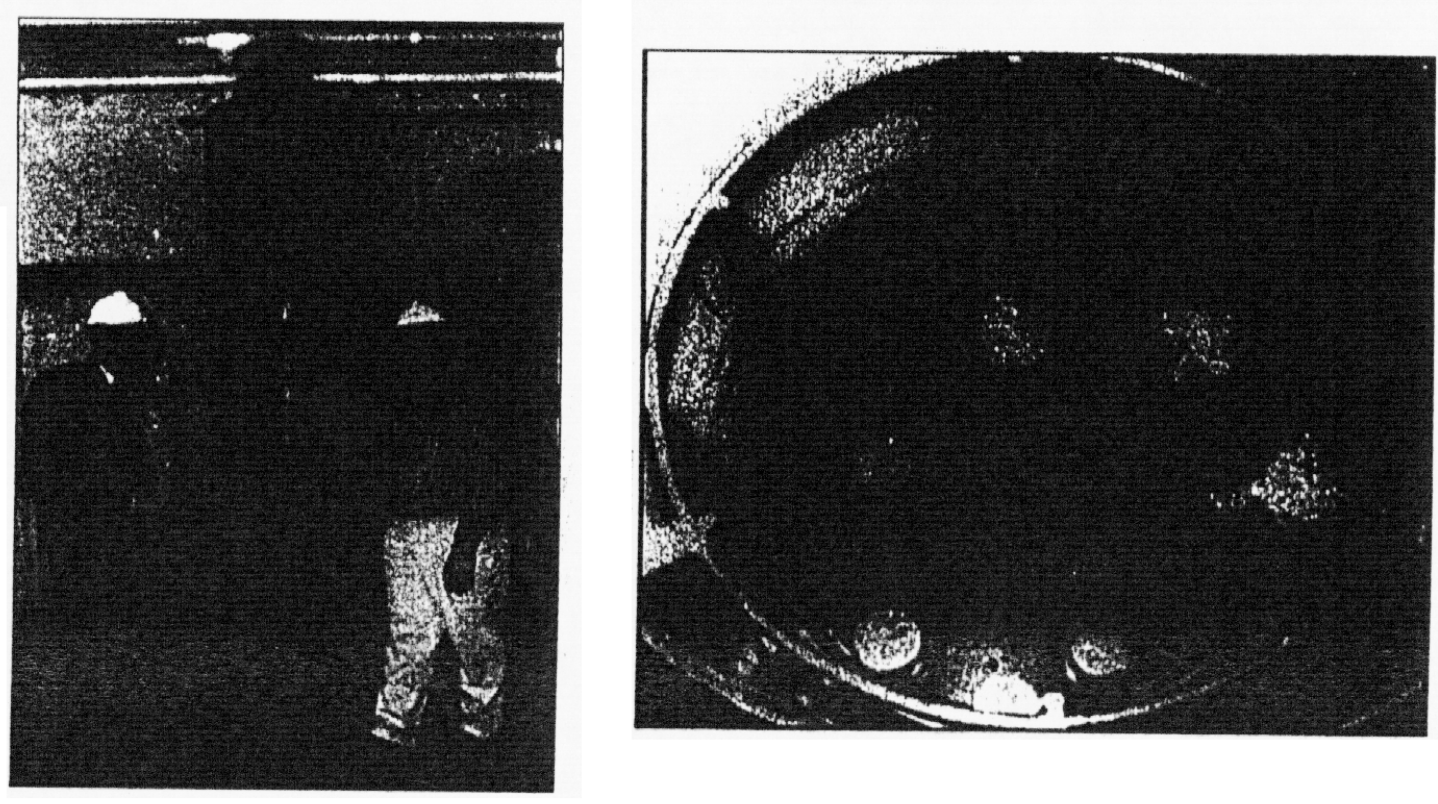


\section{Immobilization Process}

Pu/U Oxide

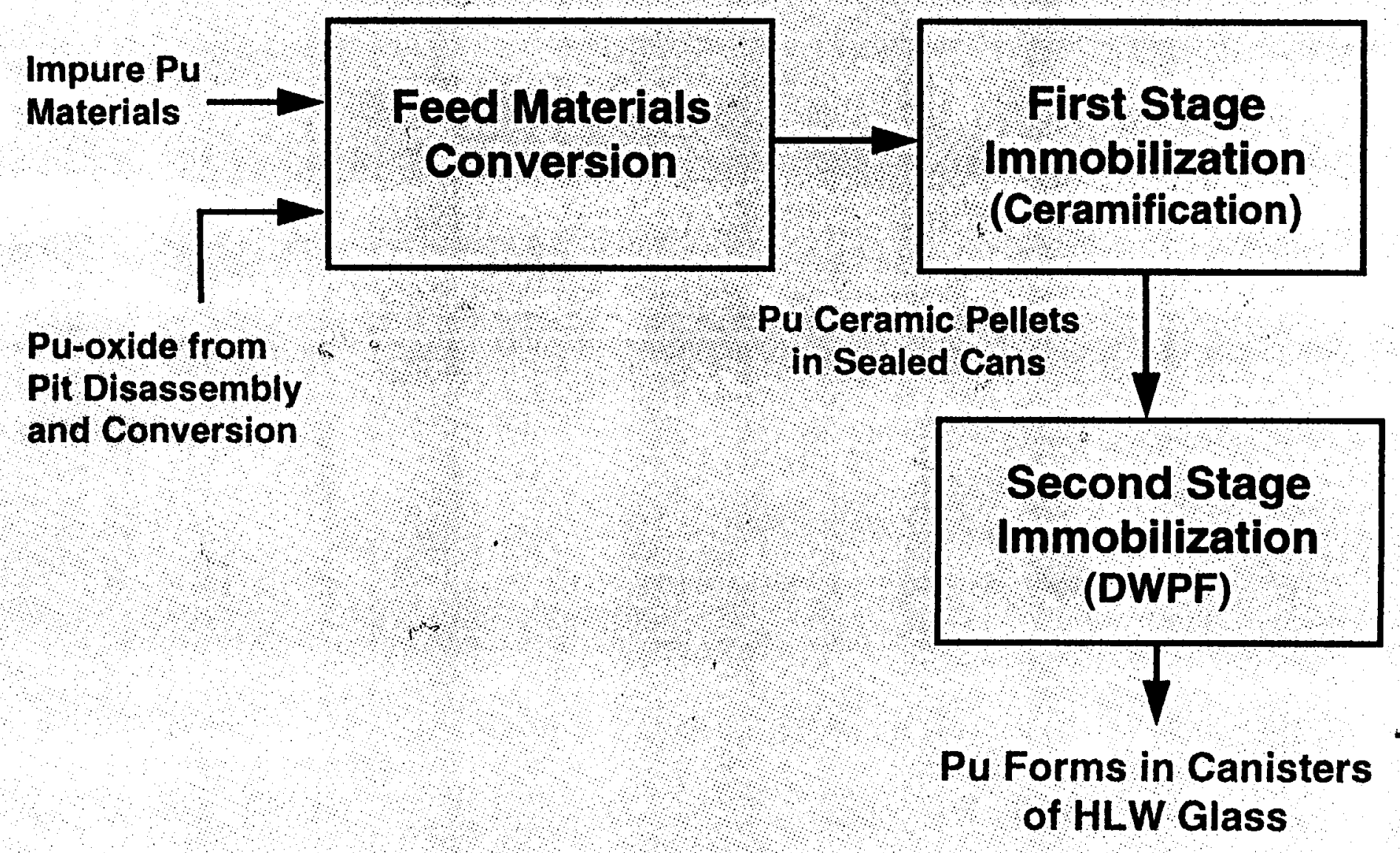




\section{Immobilization Technology Selection}

$11 / 96-1 / 97$

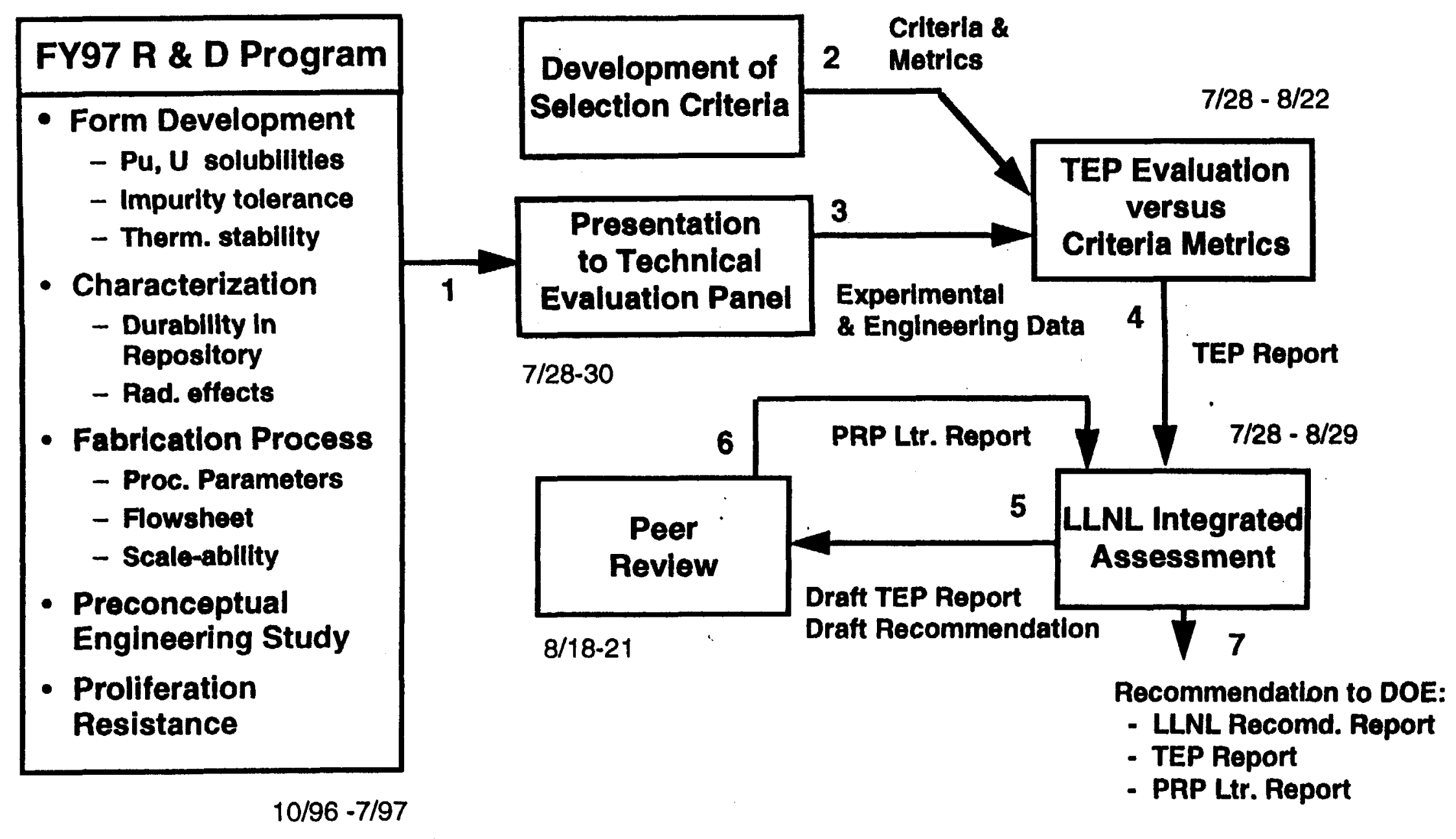




\section{Peer Review Panel}

- Matt Bunn, Chairman - Non-proliferation

- Harvard Kennedy School of Government

- Dr. Donald Langmuir - Geo-chemistry \& waste form performance

- Consultant and Professor Emeritus, Colorado School of Mines

- Dr. Ronald Loehman - Ceramics/glass science

- Head of UNM/SNL Advanced Materials Laboratory, SNL

- Dr. David Stahl - Repository performance

- Mgr. Waste Package Materials Dept. for YMP, Framatome/B\&W

- Alan Williams - Plutonium processing, facilities and operations

- Consultant, Bechtel 


\section{Ceramic Form Development Summary}

- Titanate-based ceramic form developed that accommodates high concentrations of Pu+U \& neutron absorbers ( $\mathrm{Hf} \& \mathrm{Gd}$ ):

- Baseline: 10.5 wt \% Pu, 21 wt. \% U

- Variant: 15 wt \% each Pu and U

- Form accommodates expected range of impurities without affecting distribution of $\mathrm{Pu}, \mathrm{U}, \mathrm{Hf}$, and $\mathrm{Gd}$ in desired phases

- Ceramic form is unaffected by thermal conditions of DWPF glass pour

- Ceramic is 2 to 4 orders of magnitude more durable than LaBS glass as measured by comparable leach tests

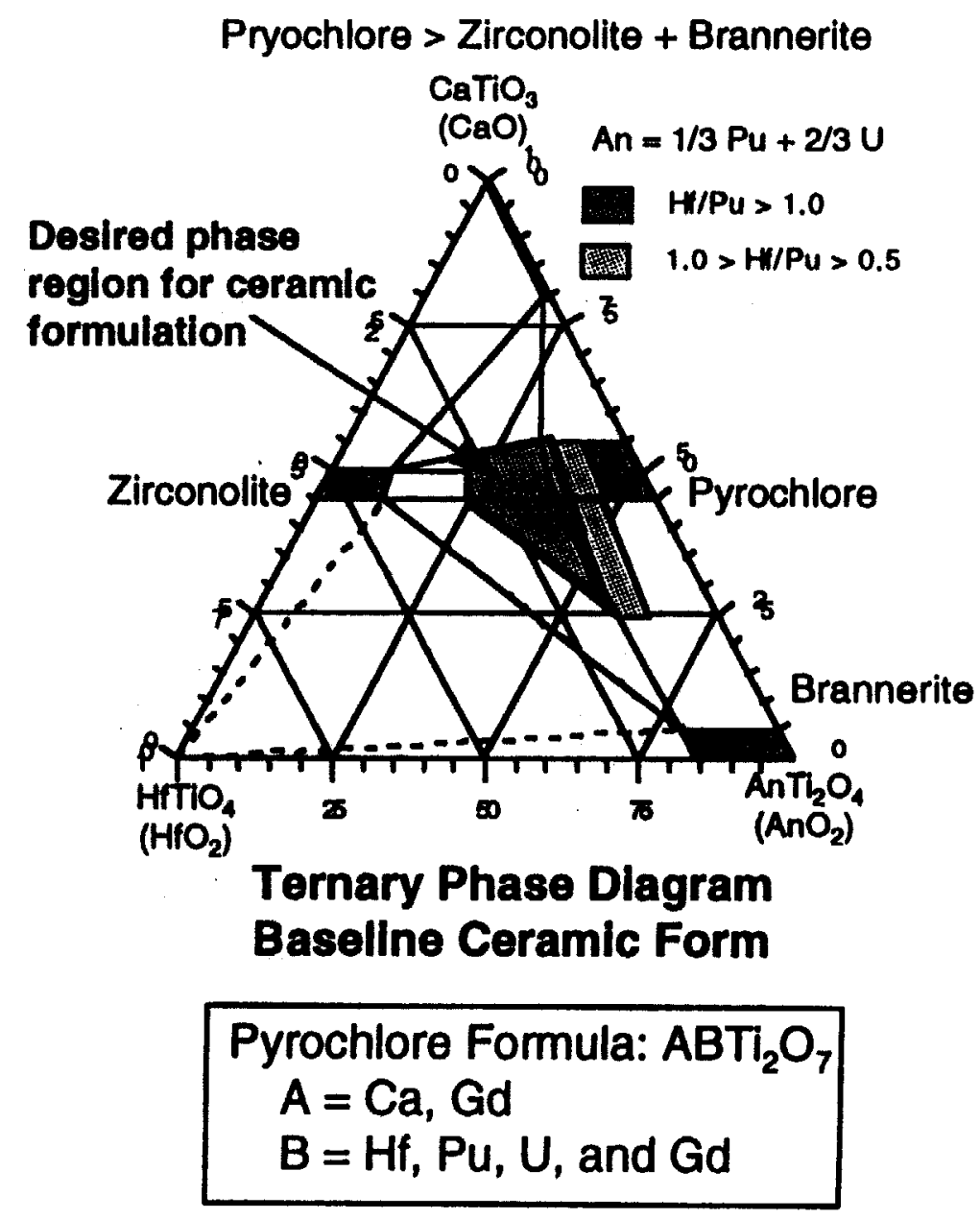




\section{Glass Form Development Summary}

- Lanthanide borosilicate LaBS) glass developed that accommodates:

- Up to 10 wt. $\% \mathrm{PuO}_{2}$ or 16 wt. \% combined $\mathrm{Pu}, \mathrm{U}$ Oxide

- Comparable amounts of Hf and Gd

- Expected range of feed impurities

- Without observable precipitation during HLW glass pour in canister; i.e., phase stable

Durability of LaBS glass in repository somewhat superior to HLW glass as measured by standard leach tests

LaBS Glass Ternary Pha e Diagram

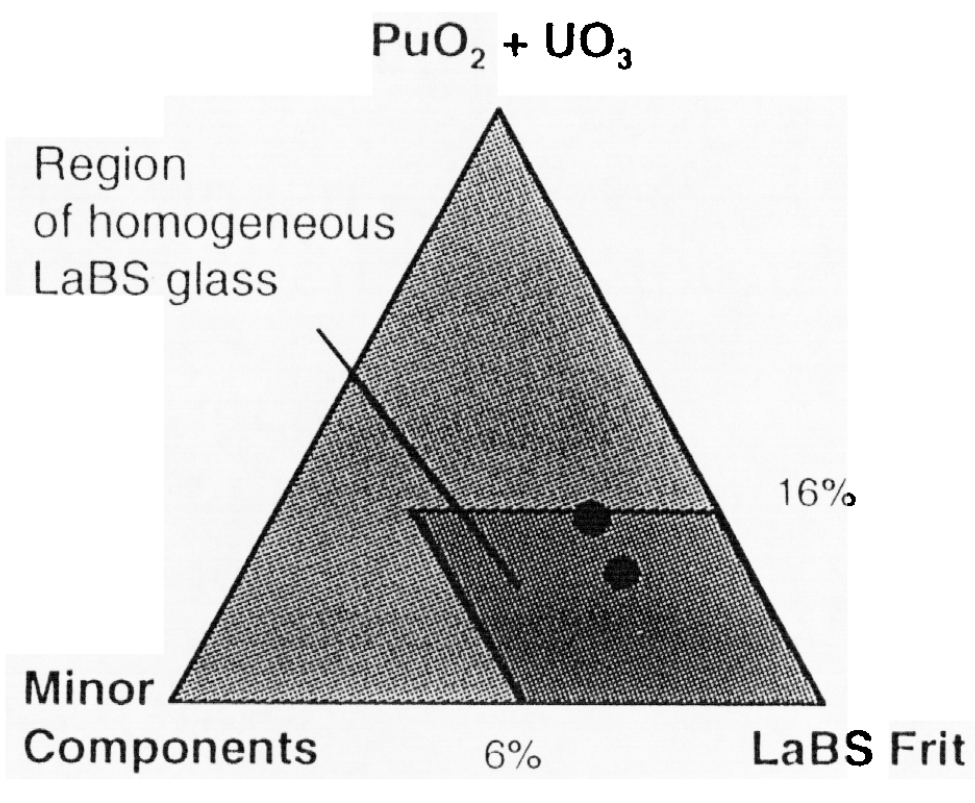

Baselines compositions:

- $(8,8,3) 17$ MT

- $(10,3,3) 50 \mathrm{MT}$ 


\section{Ceramic Process Development Summary}

MOX-like Ceramic Process

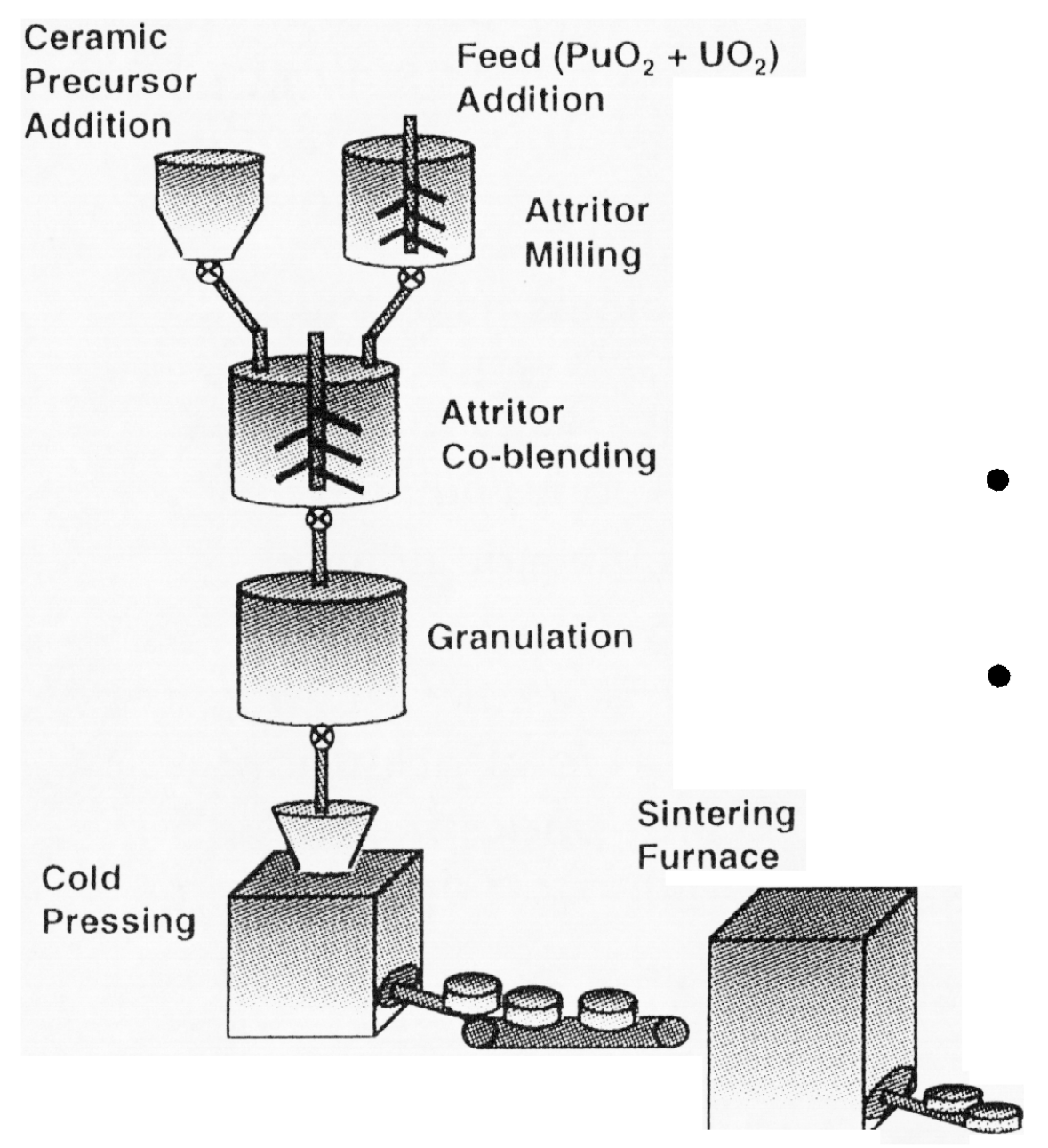

- Ceramic baseline processing parameters and flowsheet intitially defined

Expect straight-forward adaptation of MOX fuel fabrication technology

- $\quad 800$ full-size surrogate forms made in cold lab tests

- Pre-prototypic equipment installed in LLNL Pu Building for preliminary tests with actual feed materials 


\section{Glass Process Development Summary}

- Glass baseline processing parameters and production flowsheet initially defined

- Dry process

- Feed conditioning very similar to ceramic

- High temperature $\left(1500-1550^{\circ} \mathrm{C}\right)$ $\mathrm{Pt}-\mathrm{Rh}$ induction melter selected as prototype

- Initial surrogate tests with Corning melter successful

- Significant development challenges: feed system and material compatibility

- Two large-scale glass forms made with $\mathrm{Pu}$ in LLNL's tilt-pour furnace

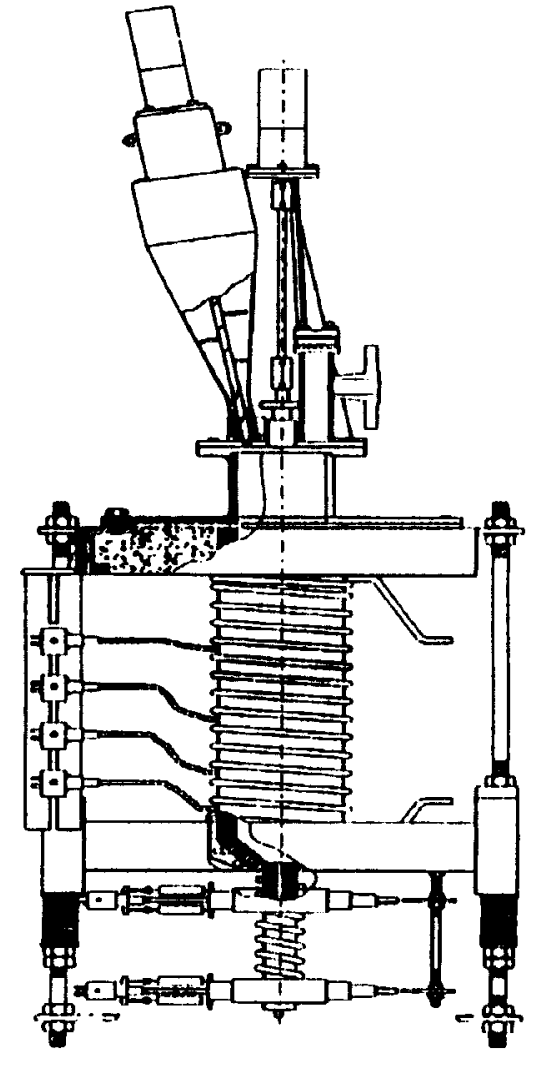

Pt-Rh Induction Melter 


\section{Characterization of Ceramic and Glass}

- Limited, but sufficient data generated on microstructure, physical properties, and dissolution (leaching) behavior of the two candidate forms

- LaBS glass: preliminary and baseline formulations with $\mathrm{Pu}$ and surrogates

- Ceramic: zirconolite-based form (early formulation) and pyrochlorebased form (baseline formulation) with $\mathrm{Pu}$ and with $\mathrm{Ce}$ surrogate

- Durability in repository

- Standard static PCT-A and PCT-B tests performed for initial and baseline forms containing Pu (ANL, SRTC, and ANSTO) w/o impurities

- Flow through tests vs. pH available for LaBS glass (PNNL and LLNL); limited data for baseline ceramic with $\mathrm{Pu}$ (LLNL)

- Pressurized unsaturated flow through (PUF) tests initiated at PNL to evaluate dissolution characteristics of forms in presence of DWPF glass (short term data available)

- Accelerated dissolution tests conducted at ANL on earlier formulations with $\mathrm{Pu}$ to determine degradation mechanisms

- Characterization of alteration phases (AEM) for leached samples under way at ANL (limited results available) 


\section{Characterization of Ceramic and Glass Forms}

- Preliminary thermodynamic data for repository assessment

- Detailed literature survey/assessment of radiation damage behavior of relevant glass and ceramic (mineral) materials

- Glass expected to essentially retain its durability level

- Ceramic form's dissolution rate, post metamictization, expected to increase by about factor of 10

- Proliferation resistance

- Pu extraction tests showed ceramic to be more robust

- White team analysis of Can-in-canister concept versus SNF Standard essentially complete; draft report being reviewed 


\section{Downselection Summary}

- Criteria and metrics developed to choose between immobilization alternatives (1/97)

- Completed evaluation that showed Can-in-canister approach preferred over homogeneous radiation barrier concepts

- Analysis documented in report issued 5/97

- Bases for preference: more timely, much lower cost, much higher technical viability, and somewhat lower ES\&H risk

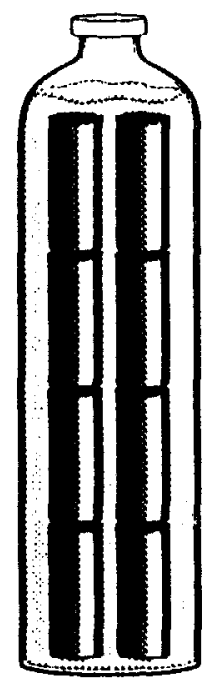

Can-in-canister Form

- Completed R\&D activities and analyses sufficient to choose between glass and ceramic technologies (7/30/97)

- Completed comprehensive three-step assessment of the candidate forms w.r.t. the criteria and metrics, and recommended ceramic as the preferred form $(8 / 30 / 97)$ 


\section{Decision Criteria}

1. Resistance to theft and diversion (Weight: 22\%)

2. Resistance to extraction \& reuse by host nation (19\%)

3. Technical viability (19\%)

4. ES \& H factors (14\%)

5. Cost effectiveness (11\%)

6. Timeliness (15\%) 


\section{Proliferation Resistance (Criteria 1 \& 2)}

1. Resistance to theft,diversion, and extraction

- Low attractiveness: I - Glass

- Minimize operations: ND

- Safeguards and security: S - Ceramic

- Difficulty of retrieval, extraction of Pu: S - M Ceramic Overall: S - Ceramic

2. Resistance to host nation reuse

- Difficulty of retrieval and extraction: I-Ceramic

- Assurance of detection: ND

Overall: I-Ceramic

Advantage Key

No Difference

- Insignificant

- Small

- Medium 


\section{Technical Viability}

- Technical maturity *

- Form (Qualification): S - Glass

- Process: S - Ceramic

- Viability risk: * ND

- Repository performance and acceptability

- Leach resistance: $M$ - Ceramic

- Effects of radiation: S - Glass

- Combined: S - M Ceramic

Overall: S - M Ceramic

* Evaluated for cost and timeliness impacts

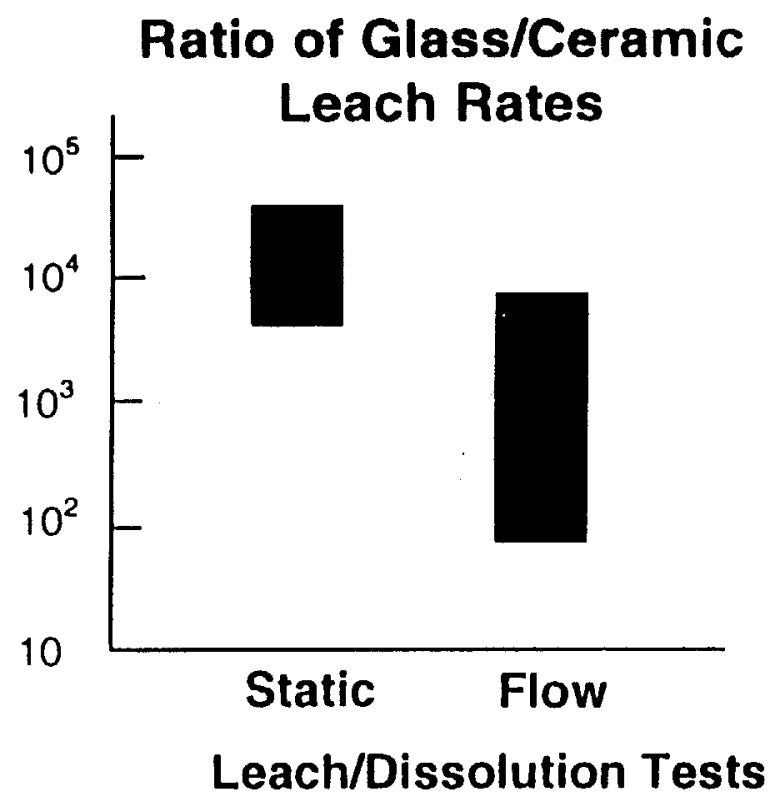

Advantage Key

No Difference

- Insignificant

- Small

- Medium 


\section{E S \& H Factors}

- No significant difference between glass and ceramic technologies for all but one ES\&H factor - worker radiation exposure

- Advantage: S - M Ceramic

- Radiation source for glass about factor eight higher than ceramic due to $\alpha, n$ reaction in boron

- Implications for glass

- More extensive automation, remote ops.

- Higher exposure potential, especially for maintenance operators

- Higher costs for shielding and automation

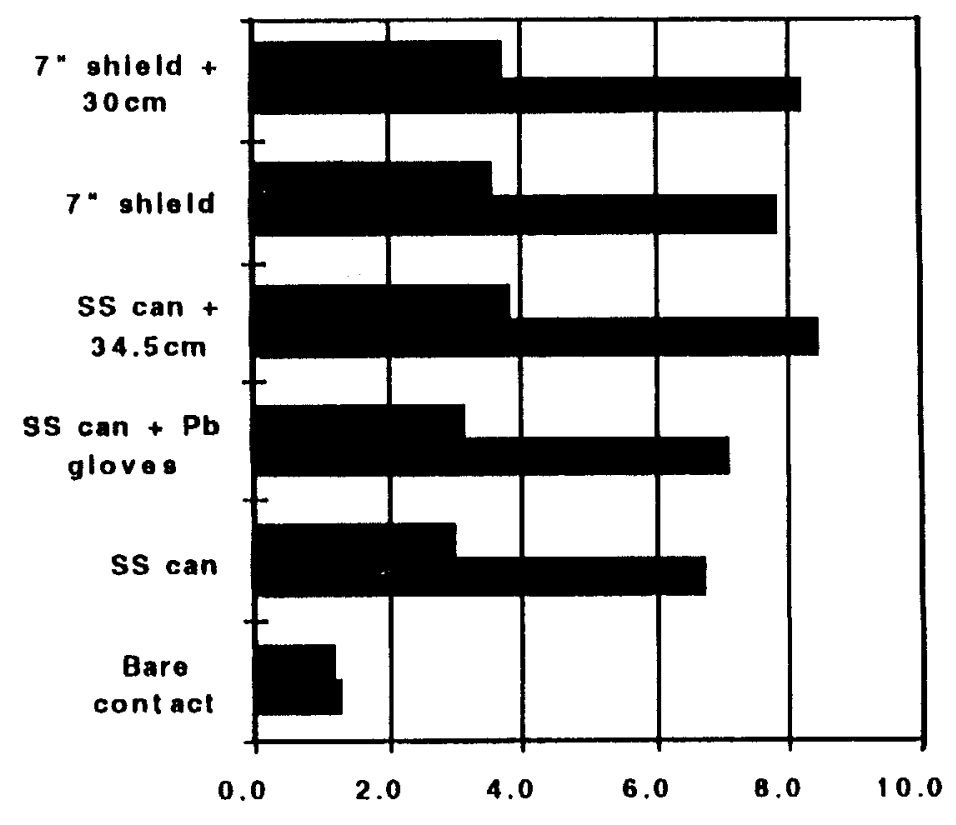

Ratio of Total Dose - Glass/Ceramic 


\section{Cost Effectiveness}

- Investment \& Life Cycle Costs

Range

- Additional canisters for glass

- Higher radiation source

- Form Qualification

- Melter

- Raw Materials
\$24M - \$70M

$>\$ 17 M-\$ 50 M$

Not eval.

Not eval.

$<\$ 20 M$
Advantage

Ceramic

Ceramic

Glass

Ceramic

Ceramic

- Use of Existing Infrastructure

- I-Ceramic

- Overall advantage: S - M Ceramic

3"ODx 22"H cans 7 columns $\times 4$ high $27 \mathrm{~kg}$ per canister $0.538 \mathrm{~g} \mathrm{Pu} \mathrm{cm}^{3}$ $11 \%$ vol. occupancy 1800 Pu canisters 200 extra canisters

THG:9/97
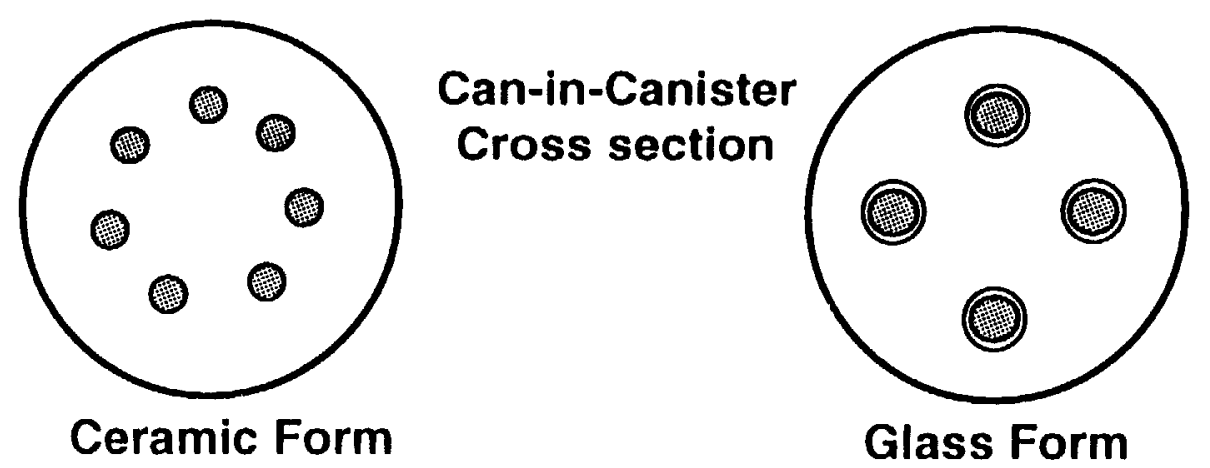

4.5"ODx 22"H cans

4 columns $\times 4$ high

$21 \mathrm{~kg}$ per canister

$0.334 \mathrm{~g} \mathrm{Pu} / \mathrm{cm}^{3}$

$14.1 \%$ vol. occupancy

2400 Pu canisters

340 extra canisters 


\section{Timeliness}

- Time to start dispostion: ND

- Time to complete disposition: ND

- Impact to existing / future missions: I - Ceramic

Advantage Key

No Difference

Insignificant

D Small

- Medium 


\section{Immobilization Technology Assessment Results}

- Both ceramic and glass technologies found to be acceptable for Pu immobilization mission

- Ceramic superior to glass due to several advantages:

- Greater robustness to theft/diversion and host nation reuse

- Greater long term durability under repository conditions

- Significantly lower radiation source during fabrication

- Significant cost savings versus glass

- More flexibility in accommodating potential changes in programmatic and technical requirements

- LLNL recommendation of ceramic form based on:

- Technical Evaluation Panel review and report (final draft, 8/29)

- LLNL assessment and recommendation report (final draft, 8/29)

- Peer Review Panel assessment and letter report (8/22) 


\section{Future Work}

- Define the range of chemical and isotopic composition of Pu feed materials to be immobilized

- Understand the primary phase relationships and the partitioning and solid solubility of impurity elements

- Finalize acceptable range of processing parameters $(t, T$, $\mathrm{P}\left(\mathrm{O}_{2}\right)$, etc.)

- Test and adapt MOX equipment and processing technology to Pu ceramic fabrication so that plant design can proceed

- Develop final canister design for can-in-canister

- Establish understanding of long-term performance of Pu ceramic for use in repository licensing 


\section{Expected Radiation Effects in Plutonium Immobilization Ceramic}

Richard A. Van Konynenburg

September 1997

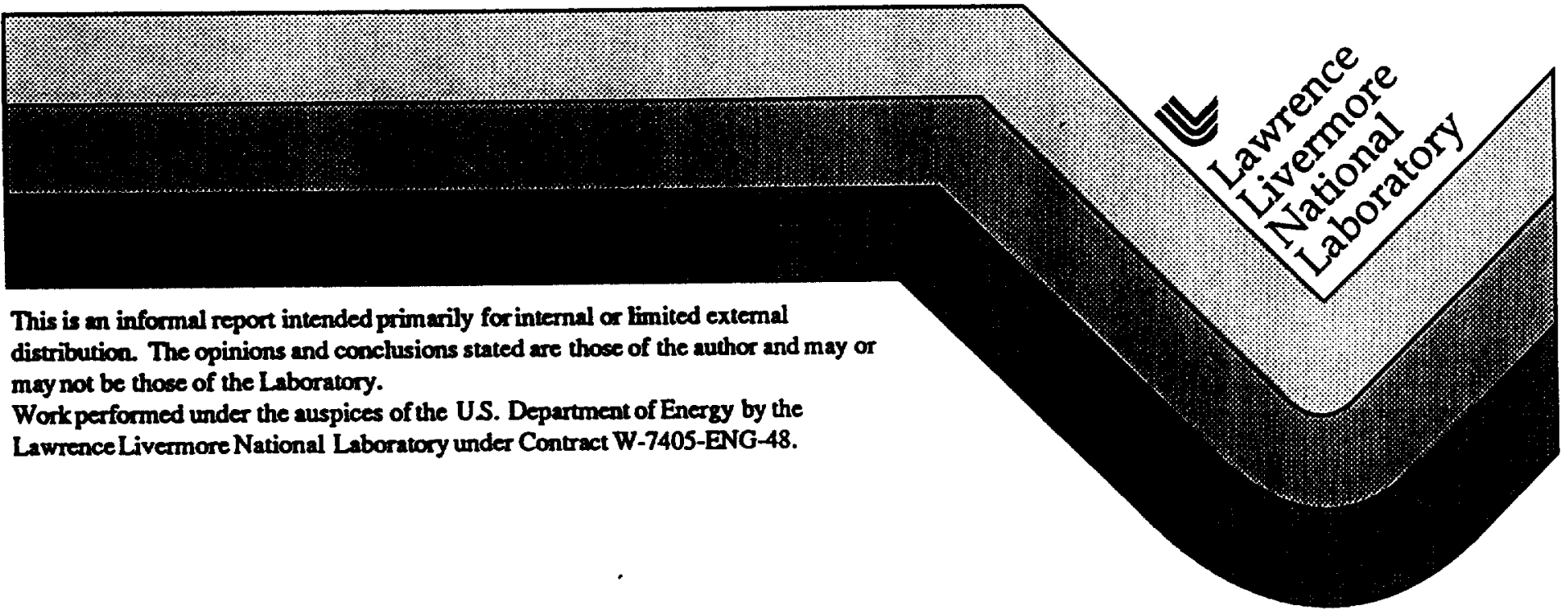




\section{DISCLAIMER}

This document was prepared as an account of work sponsored by an agency of the United States Government. Neither the United States Government nor the University of California nor any of their employees, makes any warranty, express or implied, or assumes any legal liability or responsibility for the accuracy, completeness, or usefulness of any information, apparatus, product, or process disclosed, or represents that its use would not infringe privately owned rights. Reference herein to any specific commercial products, process, or service by trade name, trademark, manufacturer, or otherwise, does not necessarily constitute or imply its endorsement, recommendation, or favoring by the United States Government or the University of California. The views and opinions of authors expressed herein do not necessarily state or reflect those of the United States Government or the University of California, and shall not be used for advertising or product endorsement purposes.

This report has been reproduced

directly from the best available copy.

Available to DOE and DOE contractors from the Office of Scientific and Technical Information

P.O. Box 62, Oak Ridge, TN 37831

Prices available from (615) 576-8401, FTS 626-8401

Available to the public from the

National Technical Information Service

U.S. Department of Commerce 5285 Port Royal Rd.,

Springfield, VA 22161 


\section{Expected Radiation Effects in Plutonium Immobilization Ceramic*}

\section{Executive Summary}

The current formulation of the candidate ceramic for plutonium immobilization consists primarily of pyrochlore, with smaller amounts of hafnium-zirconolite, rutile, and brannerite or perovskite. At a plutonium loading of 10.5 weight $\%$, this ceramic would be made metamict (amorphous) by radiation damage resulting from alpha decay in a time much less than 10,000 years, the actual time depending on the repository temperature as a function of time.

Based on previous experimental radiation damage work by others, it seems clear that this process would also result in a bulk volume increase (swelling) of about $6 \%$ for ceramic that was mechanically unconfined. For the candidate ceramic, which is made by cold pressing and sintering and has porosity amounting to somewhat more than this amount, it seems likely that this swelling would be accommodated by filling in the porosity, if the material were tightly confined mechanically by the waste package.

Some ceramics have been observed to undergo microcracking as a result of radiation-induced anisotropic or differential swelling. It is unlikely that the candidate ceramic will microcrack extensively, for three reasons: (1) its phase composition is dominated by a single matrix mineral phase, pyrochlore, which has a cubic crystal structure and is thus not subject to anisotropic swelling; (2) the proportion of minor phases is small, minimizing potential cracking due to differential swelling; and (3) there is some flexibility in sintering process parameters that will allow limitation of the grain size, which can further limit stresses resulting from either cause.

The metamictization process will convert the original, ordered titanium-oxygen polyhedral framework of the ceramic to an aperiodic, random network of corner-sharing polyhedra in which the titanium has a slightly lower average coordination number. When water in the repository eventually contacts the metamict ceramic, there will likely be leaching of a small amount of non-network ions. (Ca, $\mathrm{U}, \mathrm{Gd}$, and $\mathrm{Pu}$, in the order of decreasing expected release) from a thin layer at the surface, based on 
studies by others on natural actinide-containing mineral analogs. The titanium-oxygen network in this thin surface layer will be transformed to anatase, and the long-term release behavior of the ceramic will likely then be governed by the behavior of this layer. In the mid-pH range, titanium oxide is known to be very insoluble in water. For example, the rutile form of titanium oxide has a measured solubility in water at room temperature between $\mathrm{pH} 9$ and $\mathrm{pH} 10$ of $10^{-9}$ molal.

Very limited experimental data by others suggests that the process of metamictization may increase the release rate of plutonium from the ceramic in contact with water by a factor of one to one and one-half orders of magnitude.

Another reference point for long-term behavior is the observed condition of samples of uranium- and thorium-containing, high-titanium natural pyrochlores, which have been rendered metamict and have achieved measured ages up to a billion years. These samples are found to have substantially retained their actinides, despite their great ages. This is consistent with the low solubility of titanium oxide. 


\section{Expected Radiation Effects in Plutonium Immobilization Ceramic}

\section{Introduction}

One of the two candidate materials under development for the immobilization of excess U.S. weapons-grade plutonium is a titanate ceramic (The other is a lanthanide borosilicate glass). It is desirable that any immobilization form be able to retain the plutonium, as well as its uranium decay product and the designed-in neutron absorbers, for very long times under conditions expected in geologic disposal. This is important both to prevent nuclear criticality and to prevent release of plutonium to the environment in order to maintain radiological safety.

Because an immobilization form will contain a fairly high loading of plutonium to minimize costs, and because the dominant isotope in weapons-grade plutonium undergoes alpha decay with a half-life of 24,100 years, the form will be subject to a high rate and a high total amount of radiation damage as a result of internal alpha decay. It is important that the immobilization form maintain its capability to sequester the plutonium, its uranium decay product, and the neutron absorbers over long periods of time in the presence of this radiation damage. The most important properties in this regard are the dissolution rates of the matrix material and the leach rates of the individual elements of interest when the form is exposed to aqueous solutions.

Two approaches have been used in the past to assess the effects of radiation on ceramic nuclear waste forms: short-duration simulation experiments using actinide doping or external radiation sources (VAN KONYNENBURG, 1983), and comparison to natural mineral analogs that have successfully contained uranium and/or thorium undergoing natural radioactive decay over geologic time periods (OVERSBY, 1981; SINCLAIR, 1981; EWING, 1988; LUMPKIN, 1995). While simulation experiments have been planned for the future on the titanate ceramic candidate immobilization form for plutonium, they have not yet been carried out, and programmatic decisions must be made before the results of this work will be available. Fortunately there is a body of relevant experiments reported 
in the literature, as well as observations on relevant natural minerals, from which a great deal has been learned that is directly applicable to the plutonium immobilization problem.

This report has been written to provide a projection of radiation effects in the candidate ceramic on the basis of this past work. The plutonium immobilization ceramic is described first. Then a discussion of alpha decay and its effects on ceramics in general are presented. Next are sections on radiation damage experiments and natural mineral analogs. These are followed by brief reviews of the work on the individual mineral phases. Finally, these data are used to project radiation effects in the plutonium immobilization ceramic.

\section{Description of Plutonium Immobilization Ceramic}

Although minor changes in formulation may yet be made, the current version of the plutonium immobilization ceramic consists primarily of the mineral phase pyrochlore with smaller amounts of hafnium-zirconolite, brannerite or perovskite, and rutile. Some developmental samples have contained small amounts of plutonium oxide, but further refinement of the formulation and processing conditions will probably eliminate this phase. Therefore, its radiation damage behavior is only touched upon briefly in this report.

The pyrochlore phase in the ceramic corresponds to the group of natural minerals of the same name, which have a cubic crystal structure and the generalized formula $\mathrm{A}_{2} \mathrm{VIII}_{\mathrm{B}_{2}} \mathrm{VIX}_{7} \mathrm{IV}$, where $\mathrm{A}$ and $\mathrm{B}$ are cations, $\mathrm{X}$ are anions, and the Roman numerals indicate the coordination numbers of the ions (CHAKOUMAKOS, 1987). In the version of pyrochlore used in the candidate $\mathrm{Pu}$ immobilization ceramic, the $\mathrm{A}$ site is occupied by $\mathrm{Ca}, \mathrm{U}, \mathrm{Gd}, \mathrm{Hf}$, and $\mathrm{Pu}$, while the $\mathrm{B}$ site is occupied primarily by Ti. Oxygen is the only anion. This pyrochlore composition is somewhat similar to but more complex than $\mathrm{CaUTi}_{2} \mathrm{O}_{7}$ (DICKSON, 1989), which was used in Synroc-F (KESSON, 1983) and Synroc-FA (SOLOMAH, 1987).

The zirconolite phase in the ceramic corresponds to the natural mineral of the same name, which exists as several polytypoids (BAYLISS, 1989). The aristotype (simplest structure from which the others can be derived) of natural zirconolite is zirconolite-2M, which has a monoclinic 
structure and a general end-member formula $\mathrm{Ca}_{2} \mathrm{VIII}_{2} \mathrm{VIITi}_{3} \mathrm{VI}_{\mathrm{Ti}^{2}} \mathrm{O}_{14}$, which is usually abbreviated as $\mathrm{CaZrTi}_{2} \mathrm{O}_{7}$. Incorporation of actinides into zirconolite has been described by Vance et al. (VANCE, 1994). In the candidate plutonium-immobilization ceramic, $\mathrm{Zr}$ is completely replaced, and its site is shared by $\mathrm{Hf}, \mathrm{U}, \mathrm{Pu}$, and $\mathrm{Gd}$. An equal amount of $\mathrm{Gd}$ is also found in the $\mathrm{Ca}$ site, thus achieving charge balance. When impurity $\mathrm{Al}$ or $\mathrm{Ga}$ are present, they can be accommodated in the $\mathrm{Ti}$ site to balance $\mathrm{Gd}$ in the $\mathrm{Ca}$ site.

Brannerite has the formula $\mathrm{UTi}_{2} \mathrm{O}_{6}$ and a monoclinic structure (PABST, 1954; PATCHETT, 1960; LEJUS, 1966). It is capable of incorporating Pu, Hf, and $\mathrm{Gd}$.

A small amount of rutile $\left(\mathrm{Ti}^{\mathrm{VI}} \mathrm{O}_{2}\right.$, tetragonal) is designed to be present in the ceramic, in order to guarantee Ti-rich conditions during reactive sintering. This avoids Ca-rich conditions, which could lead to less durable minor phases. Hf substitutes for some of the $\mathrm{Ti}$ in the rutile.

Perovskite ( $\mathrm{CaXIITi} \mathrm{TiO}_{3}$, orthorhombic), when present, can incorporate rare earths and actinides (RINGWOOD, 1988).

As noted, some developmental samples have contained plutonium oxide $\left(\mathrm{PuVIIIO}_{2} \mathrm{IV}\right.$, cubic), although further refinement of the formulation and processing conditions is expected to eliminate this phase. Other minor phases may be present, depending on impurities in the plutonium feed streams, but they are not expected to contain significant quantities of $\mathrm{Pu}$.

The target overall composition of the plutonium host phase(s) at present (without impurities) is $\left(\mathrm{Ca}_{0.89} \mathrm{Gd}_{0.11}\right)\left(\mathrm{U}_{0.44} \mathrm{Hf}_{0.23} \mathrm{Pu}_{0.22} \mathrm{Gd}_{0.11}\right) \mathrm{Ti}_{2} \mathrm{O}_{7}$. This formulation includes 10.5 weight \% plutonium, and twice as much uranium as plutonium. Hafnium and gadolinium are present in molar amounts equal to that of plutonium to serve as neutron absorbers, and the uranium, principally $238 \mathrm{U}$, serves as a diluent for the fissile $235 \mathrm{U}$ that will be produced by decay of ${ }^{239} \mathrm{Pu}$, thus lowering its effective enrichment.

The ceramic is fabricated by cold pressing and sintering rather than by hot pressing in order to reduce cost and maximize process reliability and safety. This process results in a product density of $90 \%$ or more of the theoretical maximum density of $6.1 \mathrm{~g} / \mathrm{cm}^{3}$. (Although porosity is generally considered to be undesirable in a ceramic intended for structural use, it may be advantageous in this application because the residual porosity may accommodate radiation-induced swelling, which will be discussed further 
below). The grain size is typically one to a few micrometers, depending on sintering time and temperature.

\section{Plutonium Alpha Decay}

Weapons-grade plutonium typically has approximately the following isotopic make-up after its initial production (half-lives are taken from GENERAL ELECTRIC, 1996):

\begin{tabular}{|c|c|c|}
\hline Isotope & Initial Atomic \% & Half-life (years) \\
\hline${ }^{238} \mathrm{Pu}$ & 0.03 & 87.7 \\
\hline${ }^{239} \mathrm{Pu}$ & 94. & 24,100 \\
\hline $240 \mathrm{Pu}$ & 5.27 & 6,560 \\
\hline $241 \mathrm{Pu}$ & 0.5 & 14.4 \\
\hline $242 \mathrm{Pu}$ & 0.2 & $3.75 \times 10^{5}$ \\
\hline${ }^{241} \mathrm{~A} \mathrm{~m}$ & 0.0 & 432.7 \\
\hline
\end{tabular}

All the plutonium isotopes except $241 \mathrm{Pu}$ decay by alpha emission, each decay producing a helium atom (after capture of two electrons) and a long-lived uranium atom having four fewer atomic mass units than its respective parent plutonium isotope. $241 \mathrm{Pu}$ undergoes beta decay to produce ${ }^{241} \mathrm{Am}$. The ${ }^{241} \mathrm{Am}$ in turn alpha decays, producing a helium atom and a long-lived ${ }^{237} \mathrm{~Np}$ atom. The cumulative numbers of alpha decays per plutonium atom in a sample of plutonium with this isotopic composition as a function of time can be calculated from the half-lives, and are as shown in the following table. Also shown are the calculated cumulative numbers of alpha decays per gram of ceramic for a ceramic with a 10.5 weight $\%$ loading of plutonium having this isotopic composition. 
Time (years)

$\begin{array}{cc}10 & 3.66 \times 10^{-4} \\ 50 & 1.97 \times 10^{-3} \\ 100 & 4.23 \times 10^{-3} \\ 1,000 & 3.70 \times 10^{-2} \\ 10^{4} & 0.275 \\ 10^{5} & 0.945 \\ 10^{6} & 1.00\end{array}$

Alpha Decays per Gram

$9.6 \times 10^{16}$

$5.2 \times 10^{17}$

$1.1 \times 10^{18}$

$9.7 \times 10^{18}$

$7.2 \times 10^{19}$

$2.5 \times 10^{20}$

$2.6 \times 10^{20}$

Each alpha decay emits an alpha particle in a random direction and a recoiling heavy nucleus in the opposite direction, thus conserving momentum. The average alpha particle energy for this isotopic mix is 5.2 $\mathrm{MeV}$, and the average recoil nucleus energy is $87 \mathrm{keV}$. These are calculated from data given in LEDERER, 1978. The alpha particles have a range of about 10 micrometers (KRANE, 1988), and the recoil nuclei about 50 nanometers (VAN KONYNENBURG, 1983).

\section{Effects of Internal Alpha Decay on Ceramics}

The alpha particles lose energy primarily by ionization and excitation of electrons because of their high initial velocities relative to those of the orbital electrons, but near the end of their ranges some of their energy goes into elastic collisions with nuclei in the ceramic, causing the breaking of bonds and displacement of atoms from their lattice sites. Each alpha particle produces about 120 atomic displacements (VAN KONYNENBURG, 1983). Each displacement constitutes a Frenkel pair, consisting of one interstitial atom and one vacancy. Each recoil nucleus loses energy primarily by atomic collisions, and displaces about 980 atoms from their lattice sites (VAN KONYNENBURG, 1983). These displacements are concentrated along the tracks of the recoil nuclei. (Some authors quote higher numbers of displacements, depending on the values "of parameters used in the calculation, but the ratio of the number of displacements for recoil nuclei to those for alpha particles is still generally estimated as about one order of magnitude.) Atomic displacements resulting from beta decay of $\mathrm{Pu}-241$ are negligible in number in comparison to those produced by 
alpha decay of the other isotopes because of the large mass mismatch between the beta particles and the atoms in the ceramic and because much of the Pu-241 will have decayed to Am-241 at the time the ceramic is fabricated.

If a ceramic is an electrical insulator (as is true for the titanates), many of the ionized electrons are trapped in non-equilibrium states, forming electron-hole pairs. However, since titanates have not been found to be subject to displacement of atoms as a result of ionization (a process called radiolysis or ionization damage), the ionization does not have a significant effect on the structure of the ceramic. (Note that some other insulating solids, in particular the alkali halides, quartz, and some silicates, exhibit radiolysis damage, which produces chemical decomposition, in some cases at fairly low doses (HOBBS, 1994)).

In addition to producing atomic displacements, the alpha decay process transmutes all the plutonium nuclei to long-lived uranium nuclei (except for $241 \mathrm{Pu}$, which is transmuted to neptunium, as discussed earlier), and these are probably injected initially mostly into interstitial positions in the crystal lattice, because of their high recoil energy. Each alpha decay also injects a helium atom into the ceramic, which has very low solubility, and is usually trapped in a vacant lattice site, a lower energy configuration than in an interstitial site. Unless the temperature is raised to a significant fraction of the absolute melting point, the helium remains trapped and does not agglomerate into large bubbles.

If the grain size of the ceramic is large compared to the range of the recoil nuclei, as is true in the present case (one to a few micrometers, as compared with tens of nanometers), the rate of atomic displacement in each grain will be essentially proportional to the concentration of plutonium in that grain. In the case of a ceramic having more than one phase, each having a different $\mathrm{Pu}$ concentration, as is true of the $\mathrm{Pu}$ immobilization ceramic, this means that the rate of atomic displacements will be different for each phase.

Once a damage track has formed in a crystalline ceramic as a result of the passage of a recoil nucleus from alpha decay, the displaced atoms are subject to solid state diffusion, which will tend to anneal the damage and restore the crystal structure. The degree to which this occurs in a given case depends on temperature and time, as with any Arrhenius diffusive 
process. In addition, the nature of the original crystal structure is also important. The more topologically complex the structure, and the larger the number of distinguishable cation sites it contains, the smaller the recovery that will occur under a given time-temperature scenario.

For cases in which the damage anneals slowly relative to the rate of production of additional damage, new damage tracks may overlap existing ones, eventually leading to metamictization (amorphization of the crystal structure) (EWING, 1987), as observed by $x$-ray diffraction, transmission electron microscopy, XAFS and XANES. In such cases, an expansion of the crystal lattice is observed in the early stages of the process, while most of the material still remains crystalline. At higher degrees of damage the crystallinity is lost, and the material eventually undergoes swelling by several percent. The structure of the fully damaged, metamict state appears to be an aperiodic, random network of corner-sharing polyhedra, resembling that of glass, but in a different thermodynamic state than nonirradiated glass. (For example, when silica glass is irradiated, it undergoes a volume contraction of about $3 \%$ to form what has been called the "compacted state of vitreous silica," which is quite different from nonirradiated silica glass.) In forming the metamict structure the longrange order is destroyed, but the short-range order and the primary coordinations of the cations are essentially preserved. (Recent evidence from XANES indicates that the coordination number of titanium in zirconolite changes from predominantly six to predominantly five as the minerals become metamict (FARGES, 1997).)

If more than one phase is present, adjacent grains may swell at different rates because of different solid state characteristics and/or different plutonium concentrations; this is termed differential swelling. If a particular phase has a noncubic crystal structure, it can swell anisotropically. Differential and anisotropic swelling have been found to cause grain separation or microcracking in some ceramics. The tendency to form microcracks can be countered by the choice of single-phase or nearly single-phase ceramics having cubic crystal structures to minimize both anisotropic and differential swelling, and/or by keeping the grain size small (of the order of one micrometer or less), thus limiting the magnitude of the swelling-produced stresses. In the present case, the cubic mineral 
pyrochlore has been selected to dominate the ceramic, and the grain size can be limited to some extent by choice of appropriate sintering conditions.

\section{Radiation Damage Experiments}

A considerable body of experimental work has been reported in the literature concerning the effects of radiation on ceramics in general, and on the particular phases of interest for the plutonium immobilization ceramic. Radiation effects on ceramics in general have been reviewed (CLINARD, 1986a; HOBBS, 1994). Radiation effects on nuclear waste forms, including most of the phases of current interest, were reviewed recently by Ewing, Weber, and Clinard (EWING, 1995). Pertinent references from these reviews that apply to the candidate ceramic are cited below.

Because it is desirable to predict the behavior of the ceramic for long times on the basis of relatively short-term laboratory experiments, radiation damage researchers make use of methods that will increase the damage rate several orders of magnitude over what will occur in the actual waste form. This raises the question of whether such experiments constitute accurate simulations, i.e., whether there is a significant damage rate effect. This question has been examined by several researchers for each phase of interest, since their annealing rates differ. For pyrochlore and zirconolite, the annealing rates have been found to be very slow, but measurable using samples in the billion-year age range (LUMPKIN, 1995).

The type of radiation used in the experiments is also important. The most accurate simulation of the effects of internal alpha decay of plutonium is made by the method of actinide doping, in which a shorter half-life actinide, usually ${ }^{238} \mathrm{Pu}$ (87.7 years) or ${ }^{244} \mathrm{Cm}$ (18.1 years), is incorporated into the samples by ionic substitution when they are initially fabricated. Other approaches have included ion bombardment, which is suitable only for samples thinner than a few tens of nanometers, but is nevertheless useful for determining the progress of metamictization, and neutron irradiation, which produces a different physical distribution of displacements (particularly in polyphase ceramics) and a different recoil energy spectrum from internal alpha decay of dissolved actinides, but is capable of uniformly irradiating thick samples. 
Selected radiation damage experiments are discussed below for each crystalline phase of interest. The observed phenomena have included the state of order of the material, microstructure, lattice parameter changes resulting from internal stress, volume expansion or swelling, stored energy, microcracking, fracture toughness, hardness, annealing behavior and dissolution or leaching. This brief review focuses on those properties of importance for the plutonium immobilization application, principally metamictization, swelling, microcracking, dissolution, and leaching.

\section{Natural Analog Mineral Studies}

One of the major advantages of the use of ceramics for immobilizing plutonium is that it is possible to select ceramic phases that have very high chemical durability, as evidenced by the fact that they are found in nature as minerals that have successfully retained uranium and/or thorium for times of the order of billions of years, even though the minerals have been rendered metamict by the alpha decay of these elements and their progeny (EWING, 1988). The ages can be determined by radioactive dating. The ages determined by different methods can also be compared to see if they are concordant, and thus whether the various members of the radioactive decay chains have been retained in the material. In addition, the samples can be characterized by a range of techniques to determine whether geochemical alteration has occurred.

Because of the much longer half-lives of the uranium and thorium isotopes found in naturally occurring minerals than the plutonium halflives given above, the dose rates in natural samples are orders of magnitude lower than in the plutonium immobilization ceramic. The significance of this depends again on the rate of annealing for a particular mineral phase. As noted above, the major phases of interest exhibit extremely slow annealing, which tends to make the damage process independent of the damage rate. In any case, by the use of natural mineral studies in combination with laboratory radiation damage experiments, the anticipated dose rate for the plutonium immobilization ceramic can be bracketed.

Another point that should be mentioned is that the chemical compositions of natural minerals having the crystal structures of interest in 
some cases may differ substantially from those of the corresponding phases in the planned ceramic for plutonium immobilization. However, the radiation damage behavior for minerals with a given crystal structure has been found to be similar for the range of composition variations found to occur.

A final issue of importance is that the chemical and thermal environments experienced by the natural minerals over their lifetimes are not known in detail, and must be inferred from their geologic milieu and from what can be learned by examining them. Nevertheless, natural analog minerals have provided valuable insights into the long-term behavior of crystalline materials subjected to radiation damage. This type of information is not available for proposed immobilization forms that are not found as actinide hosts in nature.

\section{Consideration of Individual Mineral Phases}

\section{Pyrochlore}

Wald, Weber et al. (WALD, 1982; 1984; WEBER, 1985; 1986) studied the effects of internal alpha decay on 3 wt. \% ${ }^{244} \mathrm{Cm}$-doped $\mathrm{Gd}_{2} \mathrm{Ti}_{2} \mathrm{O}_{7}$ pyrochlore. The material was made by cold-pressing and sintering at $1400^{\circ} \mathrm{C}$ for 46 hours, and had a porosity of $14.2 \%$. The grain size was not reported. The pyrochlore became fully amorphous at a dose of 1.7 to $1.9 \mathrm{x}$ $10^{25}$ alpha decays $/ \mathrm{m}^{3}$ (2.9 to $3.2 \times 10^{18}$ alpha decays per gram) at an estimated storage temperature of $50^{\circ} \mathrm{C}$. It underwent bulk swelling, exponentially approaching a saturation value of 5.1 volume \%. It reached $1-(1 / \mathrm{e})$ of this saturation value at a dose of $9 \times 10^{24}$ alpha decays per $\mathrm{m}^{3}$ (1.5 $\times 10^{18}$ alpha decays per gram). For material made with a porosity of $9.5 \%$, the swelling saturated at $5.6 \%$. No significant microcracking was observed as a result of the swelling and amorphization up to a dose of $2.3 \mathrm{x}$ $10^{25}$ alpha decays per $\mathrm{m}^{3}\left(3.7 \times 10^{18}\right.$ alpha decays per gram).

Wald and Weber measured the effects of alpha decay on the dissolution kinetics of the pyrochlore in distilled water at $90^{\circ} \mathrm{C}$ for 14 days, by comparing the behavior of fully damaged material having an accumulated dose of $2.9 \times 10^{25}$ alpha decays per $\mathrm{m}^{3}$ (or $4.7 \times 10^{18}$ alpha decay per gram) to that of material that had been fully damaged and then annealed back to the crystalline state by heating to $1100^{\circ} \mathrm{C}$ for 12 hours. 
This approach insured that the overall chemical compositions of the samples and the radiolytic conditions in the leachant were the same for the two cases. Their results are reproduced in the following table:

\begin{tabular}{|c|c|c|c|c|c|c|}
\hline \multirow[t]{2}{*}{$\begin{array}{l}\text { Sample } \\
\text { Condition }\end{array}$} & \multirow[t]{2}{*}{$\begin{array}{c}\text { Percent weight loss } \\
\text { of sample }\end{array}$} & \multicolumn{4}{|c|}{$\begin{array}{c}\text { Normalized elemental } \\
\text { mass loss }\left(\mathrm{g} / \mathrm{m}^{2}\right)\end{array}$} & \multirow[t]{2}{*}{$\frac{\text { Final }}{\mathrm{pH}}$} \\
\hline & & $\underline{\mathrm{Gd}}$ & $\underline{\mathrm{Ti}}$ & ${ }^{244} \mathrm{Cm}$ & ${ }^{240} \underline{\mathrm{Pu}}$ & \\
\hline Crys & 0.02 & $\mathrm{ND}^{*}$ & $<0.02$ & 0.01 & 0.12 & 5.6 \\
\hline Amo & 0.05 & ND & $<0.02$ & 0.17 & 5.93 & 5.3 \\
\hline
\end{tabular}

$(* \mathrm{ND}=$ not determined $)$

As can be seen, the overall weight loss of the amorphous sample, though still small, was a factor of 2.5 larger than that of the crystalline sample. Because the $\mathrm{Ti}$ concentration in the leachate was found to be below the detection limit in both cases, it appears that either titanium was solubilitylimited or that the titanium oxide framework resisted dissolution, and continued to do so after amorphization. This is consistent with the extremely low solubility of $\mathrm{TiO}_{2}$ in water. The results for the non- $\mathrm{TiO}_{2}$ framework species $\mathrm{Cm}$ and $\mathrm{Pu}$, on the other hand, show increases by factors of 17 and 49, respectively, indicating that they were not as tightly bound or as well protected from leaching in the case of the amorphous material. Their concentrations are also consistent with the fact that their solubilities under the prevailing $\mathrm{pH}$ and redox conditions, although low, are not as limited as that of titanium. The observation that the $\mathrm{Pu}$ exhibited a larger increase in release than the $\mathrm{Cm}$ is probably related to the fact that much of it was born as recoil nuclei from alpha decay after the ceramic was made, and was thus injected into the material in a highly irreversible fashion, ending up in positions in the amorphous sample that were likely less tightly bound than those it occupied in the annealed, crystalline sample after solid-state diffusion took place. This same rationale has been applied to explain the leaching results for natural minerals, which show that the isotopes of $U$ and $T h$ that result from alpha decay exhibit higher releases than corresponding isotopes of the same elements that were present when the minerals formed (EYAL, 1982). 
Clinard et al. studied the behavior of "238Pu-substituted zirconolite," which in fact has the cubic structure of pyrochlore (CLINARD, 1984b; 1985; 1986b; 1991; FOLTYN, 1985). They fabricated the material by coldpressing and sintering for 16 to 24 hours at temperatures of 1350 to $1400^{\circ}$ C. The grain sizes were 10 to 20 micrometers, and the porosity was 7 to $10 \%$. The volume fraction of minor phases was 5 to $12 \%$. They found that the material, when stored under ambient conditions at about $75^{\circ} \mathrm{C}$, became metamict and swelled to a saturation value of 5.4 bulk volume\% at a dose of 2 to $3 \times 10^{25}$ alpha decays per $\mathrm{m}^{3}$ ( 3 to $5 \times 10^{18}$ alpha decays per gram). No radiation-induced microcracking was observed. When stored at $300^{\circ} \mathrm{C}$ the material swelled more slowly, and the swelling saturated at $4.3 \%$. When stored at $600^{\circ} \mathrm{C}$ the material remained crystalline and swelled only $0.4 \%$. No leach testing was performed on this material, but it is significant to note that the saturation value of the swelling at the ambient storage temperature was equal to that of the $\mathrm{Cm}$-doped $\mathrm{Gd}_{2} \mathrm{Ti}_{2} \mathrm{O}_{7}$ pyrochlore studied by Weber et al., i.e. 5.4 compared to 5.1 to $5.6 \%$. This suggests that the radiation damage behavior of pyrochlore is not very sensitive to its chemical composition, at least for the compositions used.

Natural pyrochlore mineral samples have received extensive study, particularly by Lumpkin, Greegor, Ewing, and co-workers (GREEGOR, 1985a; 1985b; 1987; LUMPKIN, 1980; 1985; 1986a; 1986b; 1986d; 1987; 1988a; 1988 b; 1989; 1992; 1994; 1995; 1996). Lumpkin and Ewing analyzed alpha-decay damage in pyrochlores having a wide range of chemical compositions, from 15 locations, with ages ranging up to 1.4 billion years. They also studied geochemical alteration of large numbers of samples from a variety of locations classified in the pyrochlore, microlite, and betafite subgroups of the pyrochlore group, with ages up to 1.3 billion years. They found that the mean life for an alpha recoil damage track in crystalline pyrochlore material is limited by annealing to about 100 million years at ambient geologic temperatures. This, together with their high actinide contents, accounts for the observation that most natural actinide-bearing pyrochlore minerals are found in the metamict state.

The pyrochlore phase in the $\mathrm{Pu}$ immobilization ceramic is most similar to natural minerals of the betafite subgroup (MAZZI, 1983). As noted earlier, the pyrochlore minerals have a cubic crystal structure and the general formula $\mathrm{A}_{2} \mathrm{~B}_{2} \mathrm{X}_{7}$, where $\mathrm{A}$ represents large cations, $\mathrm{B}$ consists of 
small cations, and $\mathrm{X}$ represents anions. The betafite subgroup is high in $\mathrm{Ti}$, with $2 \mathrm{Ti}$ being greater than or equal to $\mathrm{Nb}+\mathrm{Ta}$ for the B-site cation population.

Lumpkin and Ewing examined betafite pyrochlores from nine locations, all of which were metamict, having received doses of more than 3 x $10^{20}$ alpha decays per gram. Some of them had ages of 550 million and 1 billion years. Minerals of the betafite subgroup were found to have undergone some secondary alteration, apparently by relatively low temperature and relatively acidic groundwater having low activities of $\mathrm{Na}$, $\mathrm{Ca}$, and $\mathrm{F}$. Although the precise conditions of alteration could not be determined, the observed secondary phases and host-rock alteration were judged to be consistent with near-surface weathering processes at temperatures $<100^{\circ}$, resulting in increased concentrations of $\mathrm{Fe}, \mathrm{Sr}, \mathrm{Ba}, \mathrm{K}$, and $\mathrm{Al}$ in the minerals. The first stage of these processes was found to involve hydration and leaching of $\mathrm{F}, \mathrm{Na}, \mathrm{Ca}$, and $\mathrm{O}$ from the minerals, but the $U$ and $T h$ contents remained relatively constant.

For material that had undergone more extreme leaching, the betafite had altered to liandratite + rutile + uranpyrochlore. (Both liandratite and uranpyrochlore are uranium-containing minerals.) In these cases some uranium was lost. They found, however, that the least mobile A-site cations were the $3+$ oxidation-state lanthanide rare earth elements, $\mathrm{Th}^{4+}$, and $\mathrm{U}^{4+}$, and that the rate of ion exchange exceeded the total dissolution rate, governed primarily by the stability of the octahedral framework when occupied by $\mathrm{Nb}, \mathrm{Ta}$, and $\mathrm{Ti}$.

Lumpkin and Ewing concluded that actinides were effectively retained by microlite, pyrochlore, and most betafite subgroup samples for geological time periods up to 1.4 billion years. It is significant to note that their results again point to the importance of the Ti-containing framework in resisting dissolution, even after the crystal structure has been rendered amorphous, as was suggested by the experiments of Weber et al. on synthetic pyrochlore.

\section{Zirconolite}

Zirconolite is the principal actinide host phase of the high-level waste ceramics Synroc B, Synroc C, and Synroc D, (RINGWOOD, 1988; RYERSON, 1983) and has thus been the subject of considerable radiation-damage 
study (VAN KONYNENBURG, 1983; RINGWOOD, 1988; REEVE, 1991; SMITH, 1993; JOSTSONS, 1994).

Wald et al. (WALD, 1982) performed radiation damage studies on 3 wt. \% ${ }^{244} \mathrm{Cm}$-doped $\mathrm{CaZrTi}_{2} \mathrm{O}_{7}$ zirconolite. The material was made by coldpressing and sintering at $1325^{\circ} \mathrm{C}$ for 40 hours. The porosity was $10.4 \%$. The grain size was not reported. The swelling was observed by $\mathrm{x}$-ray diffraction to be anisotropic, and it saturated at 6.0 bulk volume $\%$, reaching (1-1/e) of this value at a dose of $1.0 \times 10^{25}$ alpha decays per $\mathrm{m}^{3}\left(2.5 \times 10^{18}\right.$ alpha decays per gram). Material with a lower porosity (5.2\%) swelled to a saturation value of $6.5 \%$. The material was fully metamict at a dose of 2.1 to $2.3 \times 10^{25}$ alpha decays per $\mathrm{m}^{3}$ (5.2 to $5.7 \times 10^{18}$ alpha decays per gram). No microcracking was observed, in spite of the anisotropic swelling. This may have been the result of small grain size, but this cannot be confirmed, since the grain size was not specified for the samples examined for microcracking. Dissolution testing was performed for 14 days in $90^{\circ} \mathrm{C}$ distilled water, as for pyrochlore. A comparison of the results for fully amorphous zirconolite and for material that was made fully amorphous and then annealed at $1100^{\circ} \mathrm{C}$ for 12 hours to restore its crystallinity is reproduced as follows:

\begin{tabular}{|c|c|c|c|c|c|c|}
\hline \multirow{2}{*}{$\begin{array}{l}\text { Sample } \\
\text { Condition }\end{array}$} & \multicolumn{2}{|c|}{$\frac{\text { Percent weight loss }}{\text { of sample }}$} & \multicolumn{3}{|c|}{ Normalized elemental } & \multirow[t]{2}{*}{$\frac{\text { Final }}{\mathrm{pH}}$} \\
\hline & & $\underline{\mathrm{Ca}}$ & $\underline{\mathrm{Ti}}$ & ${ }^{244} \mathrm{Cm}$ & ${ }^{240} \underline{\mathrm{Pu}}$ & \\
\hline Cry & 0.02 & 0.72 & $<0.02$ & 0.001 & 0.02 & 6 \\
\hline Amort & 0.05 & 5.99 & $<0.02$ & 0.001 & 0.22 & 7 \\
\hline
\end{tabular}

As for pyrochlore, the overall weight loss increased by a factor of 2.5 as a result of the alpha decay. Ca release increased by a factor of 8.3 , and $\mathrm{Pu}$ by a factor of 11 . The concentration of $\mathrm{Cm}$ in the solution was believed to be solubility-limited in the $\mathrm{pH}$ range of these experiments. Again, the $\mathrm{Ti}$ concentration in solution was below the limit of detection, owing to its low solubility. As for pyrochlore, it appears that the titanium oxide framework maintained its chemical durability even after amorphization, while the nonnetwork elements, in this case the $\mathrm{Ca}$ and $\mathrm{Pu}$, became more leachable. Also as for the pyrochlore work, it should be noted that much of the $240 \mathrm{Pu}$ resulted from alpha decays that occurred after the ceramic was formed, 
and thus was probably injected into less well bound configurations in the amorphous sample, making it more leachable.

Clinard et al. fabricated a zirconolite-based ceramic containing 5 mole $\%{ }^{238} \mathrm{PuO}_{2}$ for radiation damage study (CLINARD, 1984a). This material was cold-pressed and sintered for 24 hours at $1350^{\circ} \mathrm{C}$. It was found to consist of a monoclinic zirconolite matrix containing 20 vol. \% pyrochlore, 7 vol. \% rutile, and a lesser amount of an unidentified, Pu-bearing, low-Ca phase. The porosity was $9 \%$. and the grain size was about 10 micrometers. The concentration of $\mathrm{Pu}$ was about twice as high in the pyrochlore as in the zirconolite. The zirconolite was saturated with $\mathrm{Pu}$, at about 0.15 moles per formula unit.

The material was observed to become $x$-ray amorphous in 500 days, at a dose of $1.3 \times 10^{25}$ alpha decays per $\mathrm{m}^{3}\left(3.0 \times 10^{18}\right.$ alpha decays per gram). The swelling saturated at $5.5 \%$ at 800 days, corresponding to a dose of $2.1 \times 10^{25}$ alpha decays per $\mathrm{m}^{3}$ (4.8 $\times 10^{18}$ alpha decays per gram). This material exhibited microcracking, beginning at 128 days, observed to be generalized at 202 days, and reaching its maximum at 364 days. After this time, little change occurred in the crack pattern. The samples maintained their macroscopic mechanical integrity, and did not disintegrate into powder. No leach testing was performed.

The metamictization and swelling behavior of this material is seen to be fairly similar to that observed by Wald et al. for the $\mathrm{Cm}$-doped material. However, the presence of significant microcracking is an important difference. Clinard et al. explained this observation in terms of the differential swelling between the zirconolite and the pyrochlore, which sweled faster than the zirconolite because of its higher $\mathrm{Pu}$ concentration. Eventually, the swelling of the pyrochlore began to saturate, and the zirconolite swelling caught up, because they were approaching approximately the same saturation value of swelling, thus reducing the stresses and halting the cracking. The cracking that resulted from differential swelling in this material was no doubt exacerbated by the large grain size and by the fact that the faster swelling phase was surrounded by the slower swelling matrix phase, thus setting up a condition that maximized tensile stresses in the zirconolite. It is well known that brittle materials in general are weaker in tension than in compression. 
Hough and Marples also performed actinide doping experiments on zirconolite, using $4 \mathrm{wt} . \%{ }^{244} \mathrm{Cm}$ or up to $10.4 \mathrm{wt} . \%{ }^{238} \mathrm{Pu}$, and observed saturation of swelling at 4 to $7 \%$ at doses of $5-10 \times 10^{18}$ alpha decays per gram at $25^{\circ} \mathrm{C}$ with no microcracking. Their material is believed to have been of finer grain size than that of Clinard et al.

Ion bombardment experiments have also been performed on zirconolite (KARIORIS, 1982; EWING, 1992; WEBER, 1992; WHITE, 1995; SMITH, 1996). They have assisted in determining the dose at which metamictization occurs, and are essentially consistent with the actinide doping studies.

Natural samples of zirconolite are relatively rare, but nevertheless several have been characterized (OVERSBY, 1981; SINCLAIR, 1981; EWING, 1983; LUMPKIN, 1986c; 1994; 1995; HART, 1996). Lumpkin et al. found that the mean lifetime of a recoil damage track in crystalline zirconolite is about a factor of two to five longer than in pyrochlore. The transition to the metamict state occurs at doses of $10^{18}$ to $10^{19}$ alpha decays per gram. For metamict samples of ages up to 550 million years, the products of the decay of uranium and thorium to lead were generally retained, within the precision of mass spectrometric measurements (OVERSBY, 1981). The oldest known metamict natural zirconolite (2.5 billion years old) showed evidence of aqueous alteration, but it retained zirconium, thorium, uranium, and the lanthanide rare earth elements.

\section{Brannerite}

Brannerite "occurs chiefly as a primary mineral in pegmatites or as a detrital mineral derived from pegmatites or vein deposits. It has been found in the United States in placer deposits in Custer County, Idaho; at the California mine, Chaffee County and in Gilpin County, Colorado; and in Mono, Plumas, and San Bernardino counties, California. It also occurs in the Blind River district, Ontario, Canada; in the Vosges, France; near Fuenteovejuna, Cordoba, Spain; at Bou-Azzer, Morocco, and at several places in South Australia (ROBERTS, 1974)." Ore deposits containing brannerite have been described (HEINRICH, 1958). Chemical analysis shows the presence of Ca, $\mathrm{Fe}$, Th, and lanthanide rare earths as well as other minor constituents, in addition to the major elements $U$ and Ti (HEWETT, 1957). Specimens from three locations were found to be essentially metamict, but some showed a 
few weak X-ray diffraction lines (PABST, 1954). Examination of the surface of some of the specimens revealed a fine-grained, polycrystalline crust of anatase that converted to rutile upon heating. Synthesis of brannerite has been described (PATCHETT, 1960; KAIMAN, 1961; LEJUS, 1966). I am not aware of any radiation-damage studies that have been performed on this mineral, or of detailed studies of natural samples.

\section{Perovskite}

Perovskite is one of the main phases in Synroc B, C, and D. Actinide doping studies at Harwell have shown metamictization at a dose of $4.2 \mathrm{x}$ $10^{18}$ alpha decays per gram and a saturation swelling at high doses of $16 \%$. There is disagreement in the literature about the relative doses required to amorphize perovskite and zirconolite. There is some evidence that damage in natural perovskite anneals more rapidly than that in zirconolite. Since this mineral is not designed to be present in the current formulation, a detailed discussion of its radiation damage behavior is not presented.

\section{Plutonium Oxide}

Plutonium oxide does not become metamict under irradiation, but it swells to a saturation value of about $1 \%$ because of stored radiationproduced defects (TURCOTTE, 1972; 1974; WEBER, 1984).

\section{Projection of Radiation Effects in Plutonium Immobilization Ceramic}

It seems clear from the above that if stored at temperatures near ambient, the major phases in plutonium immobilization ceramic will become fully amorphous in less than 1,000 years. If the ceramic is placed in a repository in which the temperature during a significant part of this period is elevated to as much as $250^{\circ} \mathrm{C}$, which is the approximate maximum currently under discussion, the time required to achieve complete amorphization can be expected to increase somewhat, but it will still occur well before 10,000 years.

If the ceramic is not tightly confined, it will undergo swelling as a result of radiation damage. If sufficient external space is available, it will probably swell by about 5.5 to $6 \%$. If it is tightly confined, the swelling will likely be absorbed by the' porosity, because ceramics are capable of plastic 
deformation at low strain rates, and the continuing alpha decay will enhance atomic rearrangement.

It cannot be completely guaranteed that microcracking will not occur, but it is likely to be insignificant, for three reasons: (1) the candidate ceramic is dominated by a single phase, minimizing problems of differential swelling; (2) the dominant phase is pyrochlore, which has a cubic crystal structure and therefore swells isotropically, minimizing stresses resulting from anisotropic swelling; and (3) the fabrication process can be tailored to some degree to minimize the grain size, which minimizes stresses resulting from both differential and anisotropic swelling.

As the plutonium transmutes to uranium, it will be accommodated in the ceramic, because the $4+$ ions of these two species are similar in ionic radius. The helium resulting from alpha decay will be trapped in vacancies or in microvoids and much of it will probably remain there over geologic time periods.

When water eventually contacts the ceramic after it has been converted to the amorphous state, there will likely be leaching of nonnetwork ions ( $\mathrm{Ca}, \mathrm{U}, \mathrm{Gd}$, and $\mathrm{Pu}$, in the order of decreasing leachability) from a very thin layer near the surface. As these ions are leached out, the residual titanium-oxygen network will transform into a protective layer of polycrystalline titanium oxide (anatase form) on the surface. When this layer is in place, it will reduce the rate of loss of non-network ions to very small values, limited by the very low solubility of titanium oxide in water. For example, the solubility of the rutile form of titanium oxide at room temperature and $\mathrm{pH}$ between $\mathrm{pH} 9$ and $\mathrm{pH} 10$ has been measured at 10-9 molal (ZIEMNIAK, 1993). The very low solubility of hafnium will also support this protective action.

The existence of natural mineral samples of the same phases that have been selected for the candidate ceramic, that are fully metamict and that have achieved ages in the billion-year range while substantially retaining their actinides is strong testimony of the long-term durability of the candidate ceramic.

*Work performed under the auspices of the Office of Fissile Material Disposition of the U.S. Department of Energy by Lawrence Livermore National Laboratory under Contract W-7405-ENG-48 


\section{REFERENCES}

BAYLISS, 1989--Bayliss, P., Mazzi, F., Munno, R., and White, T.J., "Mineral Nomenclature: Zirconolite," Mineral. Mag. 53, 565-9 (1989).

CHAKOUMAKOS, 1987--Chakoumakos, B.C., "Pyrochlore," McGraw-Hill Yearbook of Science and Technology, S.P. Parker, ed., McGraw-Hill, Inc., New York (1987), pp. 393-5.

CLINARD, 1984a--Clinard, F.W., Jr., Rohr, D.L., and Roof, R.B., "Structural Damage in a Self-Irradiated Zirconolite-Based Ceramic," Nucl. Inst. and Meth. in Phys. Res. B1, 581-6 (1984).

CLINARD, 1984b--Clinard, F.W., Jr., "Self-Irradiation Effects in 238PuSubstituted Zirconolite, I. Temperature Dependence of Damage," J. Nucl. Mater. 126, 245-54 (1984).

CLINARD, 1985--Clinard, F.W., Jr., Livak, R.J., Hobbs, L.W., and Rohr, D.L., "Structural Changes in 238Pu-Substituted Zirconolite on Recovery from the Metamict State," Mater. Res. Soc. Proc., vol. 50, Scientific Basis for Nuclear Waste Management IX, L.O. Werme, ed., Materials Research Society, Pittsburgh, PA, pp. 371-8 (1985).

CLINARD, 1986a--Clinard, F.W., Jr., and Hobbs, L.W., "Radiation Effects in Non-Metals," Chapter 7 of Physics of Radiation Effects in Crystals, R.A. Johnson and A.N. Orlov, eds., Elsevier, New York (1986), pp. 387-470.

CLINARD, 1986b--Clinard, F.W., Jr., "Review of Self-Irradiation Effects in Pu-Substituted Zirconolite," Ceramic Bulletin 65, $1181-7$ (1986).

CLINARD, 1991--Clinard, F.W., Jr., Foltyn, E.M., and Ewing, R.C., "Stored Energy in Natural Zirconolite and Its Synthetic Counterpart After Alpha Recoil Self-Irradiation Damage," J. Nucl. Mater. 185, 202-7 (1991). 
DICKSON, 1989--Dickson, F.J., Hawkins, K.D., and White, T.J., "Calcium Uranium Titanate--A New Pyrochlore," J. Solid State Chem. 82, 146-50 (1989).

EWING, 1983--Ewing, R.C., and Headley, T.J., "Alpha-Recoil Damage in Natural Zirconolite (CaZrTi $2 \mathrm{O}_{7}$ )," J. Nucl. Mater. 119, 102-9 (1983).

EWING, 1987--Ewing, R.C., Chakoumakos, B.C., Lumpkin, G.R., and Murakami, T., "The Metamict State," MRS Bulletin, May 16/June 15, 1987, pp. 58-66.

EWING, 1988--Ewing, R.C., Chakoumakos, B.C., Lumpkin, G.R., Murakami, M., Greegor, R.B., and Lytle, F.W., "Metamict Minerals: Natural Analogues for Radiation Damage Effects in Ceramic Nuclear Waste Forms," Nucl. Instr. and Meth. in Phys. Res. B32, 487-97 (1988).

EWING, 1992--Ewing, R.C., and Wang, L.M., "Amorphization of Zirconolite: Alpha-Decay Event Damage Versus Krypton Ion Irradiation," Nucl. Inst. and Meth. in Physics Res. B65, 319-23 (1992).

EWING, 1995--Ewing, R.C., Weber, W.J. , and Clinard, F.W., Jr., "Radiation Effects in Nuclear Waste Forms for High-Level Radioactive Waste," Prog. in Nucl. Energy 29, 63-127 (1995).

EYAL, 1982--Eyal, Y."Isotopic Fractionation of Thorium and Uranium upon Leaching of Monazite: Alpha-recoil Damage Effects," Scientific Basis for Nuclear Waste Management V, Materials Research Society, p. 399 (1982).

FARGES,1997--Farges, F., "Fivefold-Coordinated Ti4+ in Metamict Zirconolite and Titanite: A New Occurrence Shown by Ti K-Edge XANES Spectroscopy," Amer. Mineral. 82, 44-50 (1997).

FOLTYN, 1985--Foltyn, E.M., Clinard, F.W., Jr., Rankin, J., and Peterson, D.E., "Self-Irradiation Effects in ${ }^{238} \mathrm{Pu}$-Substituted Zirconolite: II. Effect of Damage Microstructure on Recovery," J. Nucl. Mater. 136, 97-103 (1985). 
GENERAL ELECTRIC, 1996--Nuclides and Isotopes, Fifteenth Edition. Chart of the Nuclides, Revised by J. R. Parrington et al., GE Nuclear Energy, San Jose, CA (1996).

GREEGOR, 1985a--Greegor, R.B., Lytle, F.W., Chakaoumakos, B.C., Lumpkin, G.R., and Ewing, R.C., "An Investigation of Uranium L-Edges of Metamict and Annealed Betafite," Mater. Res. Soc. Proc., vol. 50, Scientific Basis for Nuclear Waste Management IX, L.O. Werme, ed., Materials Research Society, Pittsburgh, PA (1985), pp. 387-92.

GREEGOR, 1985b--Greegor, R.B., Lytle, F.W., Chakoumakos, B.C., Lumpkin, G.R., and Ewing, R.C., "An Investigation of Metamict and Annealed Natural Pyrochlores by X-Ray Absorption Spectroscopy," Mater. Res. Soc. Proc., vol. 44, Scientific Basis for Nuclear Waste Management VIII, C.M. Jantzen, J.A. Stone, and R.C. Ewing, eds., Materials Research Society, Pittsburgh, PA (1985), pp. 655-62.

GREEGOR, 1987--Greegor, R.B., Lytle, F.W., Chakoumakos, B.C., Lumpkin, G.R., Ewing, R.C., Spiro, C.L., and Wong, J., "An X-Ray Absorption Spectroscopy Investigation of the Ta Site in Alpha-Recoil Damaged Natural Pyrochores," Mater. Res. Soc. Proc., vol. 84, Scientific Basis for Nuclear Waste Management X, J.K. Bates and W.B. Seefeldt, eds., Materials Research Society, Pittsburgh, PA (1987), pp. 645-58.

HART, 1996--Hart, K.P., Lumpkin, G.R., Giere, R., Williams, C.T., McGlinn, P.J., and Payne, T.E., "Naturally-Occurring Zirconolites--Analogues for the LongTerm Encapsulation for Actinides in Synroc," Radiochimica Acta , (1996).

HEINRICH, 1958--Heinrich, E.W., Mineralogy and Geology of Radioactive Raw Materials, McGraw-Hill, New York (1958), pp. 49-51, 256-65.

HEWETT, 1957--Hewett, D.F., Stone, J., and Levine, H., "Brannerite from San Bernardino County, California", Amer. Mineral. 42, 30-38 (1957). 
HOBBS, 1994--Hobbs, L.W., Clinard, F.W., Jr., Zinkle, S.J., and Ewing, R.C., "Radiation Effects in Ceramics," J. Nucl. Mater. 216, 291-321 (1994).

JOSTSONS, 1994--Jostsons, A, "Status of Synroc Development," Proc. of the 9th Pacific Basin Nuclear Conference, Sydney, Australia, 1-6 May 1994, National Conference Publication No. 94/6, Australian Nuclear Assn. Inc. and The Institution of Engineers, Australia.

KAIMAN, 1961--Kaiman, S., "Synthesis of Brannerite,", Canad. Mineral. 6, 389-90 (1957-61).

KESSON, 1983--Kesson, S.E., and Ringwood, A.E., "Safe Disposal of Spent Nuclear Fuel," Rad. Waste Man. and the Nucl. Fuel Cycle 4, 159-74 (1983).

KRANE, 1988--Krane, K.S., Introductory Nuclear Physics, Wiley, New York (1988), p. 195.

LEDERER, 1978--Lederer, C.M., and Shirley, V.S., eds., Table of Isotopes, Seventh Edition, John Wiley, New York (1978).

LEJUS, 1966--Lejus, A-M., Goldberg, D., and Revcolevschi, A., "Sur Quelques Composes Nouveaux Formes par le Rutile TiO2, avec des Oxydes de Metaux Trivalents et Tetravalents," Comptes Rendes Acad. Sci. Paris 263, serie C, 1223-6 (1966).

LUMPKIN, 1980--Lumpkin, G.R., and Ewing, R.C., "Alpha-Decay Damage in Minerals of the Pyrochlore Group," Phys. Chem. Minerals 16, 2-20 (1980).

LUMPKIN, 1985--Lumpkin, G.R., and Ewing, R.C., "Natural Pyrochlores: Analogues for Actinide Host Phases in Radioactive Waste Forms," Mater. Res. Soc. Proc,. vol. 44, Scientific Basis for Nuclear Waste Management VIII, C.M. Jantzen, J.A. Stone, and R.C. Ewing, eds., Materials Reseärch Society, Pittsburgh, PA (1985), pp. 647-54. 
LUMPKIN, 1986a--Lumpkin, G.R., and Ewing, R.C., "High-Resolution Transmission Electron Microscopy of Microlite from the Harding Pegmatite, Taos County, New Mexico," Microbeam Analysis-1986, San Francisco Press, San Francisco, CA (1986), pp. 145-7.

LUMPKIN, 1986b--Lumpkin, G.R., Chakoumakos, B.C., and Ewing, R.C., "Mineralogy and Radiation Effects of Microlite from the Harding Pegmatite, Taos County, New Mexico," Amer. Mineral. 71, 569-88 (1986).

LUMPKIN, 1986c--Lumpkin, G.R., Ewing, R.C., et al., "Alpha-Recoil Damage in Zirconolite ( $\mathrm{CaZrTi}_{2} \mathrm{O}_{7}$ )," J. Mater. Res. 1, $564-576$ (1986).

LUMPKIN, 1986d--Lumpkin, G.R., Foltyn, E.M., and Ewing, R.C., "Thermal Recrystallization of Alpha-Recoil Damaged Minerals of the Pyrochlore Structure Type," J. Nucl. Mater. 139, 113-20 (1986).

LUMPKIN, 1987--Lumpkin, G.R., and Ewing, R.C., "Transmission Electron Microscopy of Alpha-Decay Damage and Alteration of Betafite," Proc. of the 45th Ann. Mtg. of the Electron Micros. Soc. of America, G.W. Bailey, ed., San Francisco Press, Inc., San Francisco, CA (1987), pp. 376-7.

LUMPKIN, 1988a--Lumpkin, G.R., and Ewing, R.C., "Alpha-Decay Damage and the Aperiodic Structure of Pyrochlore," Proc. of the 46th Ann. Mtg. of the Electron Micros. Soc. of America, G.W. Bailey, ed., San Francisco Press, Inc., San Francisco, CA (1988), pp. 470-1.

LUMPKIN, 1988b--Lumpkin, G.R., and Ewing, R.C., "Preferential Leaching and Natural Annealing of Alpha-Recoil Tracks in Metamict Betafite and Samarskite," J. Mater. Res. 3, 357-368 (1988).

LUMPKIN, 1989--Lumpkin, G.R., and Ewing, R.C., "Alpha-Decay Damage and Annealing Effects in Natural Pyrochlores: Analogues for Long-Term Radiation Damage Effects in Actinide, Pyrochlore Structure Types," Mater. Res. Soc. Proc., vol. 127, Scientific Basis for Nuclear Waste Management XII, W. Lutze and R.C. Ewing, eds., Materials Research Society, Pittsburgh, PA (1989), pp. 253-60. 
LUMPKIN, 1992--Lumpkin, G.R., and Ewing, R.C., "Geochemical Alteration of Pyrochlore Group Minerals: Microlite Subgroup," Amer. Mineral. 77, 17988 (1992).

LUMPKIN, 1994--Lumpkin, G.R., Hart, K.P., McGlinn, P.J., and Payne, T.E., "Retention of Actinides in Natural Pyrochlores and Zirconolites," Radiochimica Acta 66/67, 469-74 (1994).

LUMPKIN, 1995--Lumpkin, G.R., Smith, K.L., et al., "Prediction of the LongTerm Performance of Crystalline Nuclear Waste Form Phases from Studies of Mineral Analogues," Proc. of the 9th Pacific Basin Nuclear Conference, Sydney, Australia, 1-6 May 1994, National Conference Publication No. 94/6, Australian Nuclear Assn. Inc. and The Institution of Engineers, Australia. Lumpkin, G.R., and Ewing, R.C., "Geochemical Alteration of Pyrochlore Group Minerals: Pyrochlore Subgroup," Amer. Mineral. 80, 732-43 (1995).

LUMPKIN, 1996--Lumpkin, G.R., and Ewing, R.C., "Geochemical Alteration on Pyrochlore Group Minerals: Betafite Subgroup," Amer. Mineral. 81, 123748 (1996).

MAZZI, 1983--Mazzi, F., and Munno, R., "Calciobetafite (New Mineral of the Pyrochlore Group) and Related Minerals from Campi Flegrei, Italy; Crystal Structures of Polymignyte and Zirkelite: Comparison with Pyrochlore and Zirconolite," Amer. Mineral. 68, 262-76 (1983).

MITAMURA, 1992--Mitamura, H., Matsumoto, S., Hart, K.P., Miyazaki, T., Vance, E.R., Tamura, Y., Togashi, Y., and White, T.J., "Aging Effects on Curium-Doped Titanate Ceramic Containing Sodium-Bearing High-Level Nuclear Waste," J. Am. Ceram. Soc. 75, 392-400 (1992).

OVERSBY, 1981--Oversby, V.M., and Ringwood, A.E., "Lead İsotopic Studies of Zirconolite and Perovskite and Their Implications for Long Range Synroc Stability," Rad. Waste Man. 1, 289-307 (1981). 
PABST, 1954--Pabst, A., "Brannerite from California," Amer. Mineral. 39, 109-117 (1954).

PATCHETT, 1960--Patchett, J.E., and Nuffield, E.W., "Studies of Radioactive Compounds X--The Synthesis and Crystallography of Brannerite," Canadian Mineral. 6, 483-90 (1960).

REEVE, 1991--Reeve, K.D., "SYNROC--A High Quality Nuclear Waste Form," Ceramics Today--Tomorrow's Ceramics, Proc. of the 7th Intl. Meeting on Modern Ceramics Technologies, World Ceramics Congress,, Montecatini Terme, Italy, 24-30 June, 1990, Part D, edited by P. Vincenzini, pp. 311120, Elsevier, New York (1991).

RINGWOOD, 1988--Ringwood, A.E., Kesson, S.E., Reeve, K.D., Levins, D.M., and Ramm, E.J., "Synroc," Chapter 4 in Radioactive Waste Forms for the Future. W. Lutze and R.C. Ewing, eds., North-Holland, New York (1988), pp. 233334.

ROBERTS, 1974--Roberts, W.L., Rapp, G.R. , Jr., and Weber, J., Encyclopedia of Minerals, Van Nostrand, New York (1974), p. 85.

RYERSON, 1983--Ryerson, F.J., "Microstructure and Mineral Chemistry of Synroc-D," J. Amer. Ceram. Soc. 66, 629-36 (1983).

SINCLAIR, 1981--Sinclair, W., and Ringwood, A.E., "Effects of Nuclear Radiation on the Crystal Structures of Zirconolite and Perovskite," Geochem. J. 15,229 (1981).

SMITH, 1992--Smith, K.L., Lumpkin, G.R., Blackford, M.G., Day, R.A., and Hart, K.P., "The Durability of Synroc," J. Nucl. Mater. 190, 287-94 (1992).

SMITH, 1993--Smith, K.L., and Lumpkin, G.R., "Structural Features of Zirconolite, Hollandite, and Perovskite, the Major Waste-Bearing Phases in Synroc," Defects and Processes in the Solid State: Geoscience Applications, The McLaren Volume, J.N. Boland and J.D. Fitz Gerald, eds., Elsevier, New York (1993), pp. 401-22.' 
SMITH, 1996--Smith, K.L., Zaluzec, N.J., and Lumpkin, G.R., "In situ Studies of Ion Irradiated Zirconolite, Pyrochlore, and Perovskite," submitted to J. Nucl. Mater. in 1996.

SOLOMAH, 1987--Solomah, A.G., Richardson, P.G., and McIlwain, A.K., "Phase Identification, Microstructural Characterization, Phase Microanalyses and Leaching Performance Evaluation of Synroc-FA Crystalline Ceramic Waste Form," J. Nucl. Mater. 148, 157-65 (1987).

TURCOTTE, 1972--Turcotte, R. P., and Chikalla, T.D., "Self-Radiation Damage in 238 $\mathrm{PuO}_{2}$," BNWL-B-225, Battelle Pacific Northwest Laboratories, Richland, WA (October 1972).

TURCOTTE, 1974--Turcotte, R.P., and Chikalla, T.D., "Concentrated Defects in $\mathrm{PuO}_{2}$," Defects and Transport in Oxides. M.S. Seltzer and R.I. Jaffee, eds., Plenum Press, New York (1974), pp. 159-73.

VAN KONYNENBURG, 1983--Van Konynenburg, R.A.. and Guinan, M.W., "Radiation Effects in Synroc-D," Nucl. Technol. 60, 206-17 (1983).

VANCE, 1994--Vance, E.R., Ball, C.J., Day, R.A., Smith, K.L., Blackford, M.G., Begg, B.D., and Angel, P.J., "Actinide and Rare Earth Incorporation into Zirconolite," J. of Alloys and Compounds 213/214, 406-9 (1994).

WALD, 1982--Wald, J.W., and Offermann, P., "A Study of Radiation Effects in Curium-Doped $\mathrm{Gd}_{2} \mathrm{Ti}_{2} \mathrm{O}_{7}$ (Pyrochlore) and CaZrTi2O7 (Zirconolite)," Scientific Basis for Nuclear Waste Management V, W. Lutze, ed., Elsevier, New York (1982), pp. 369-78.

WALD, 1984--Wald, J.W., and Weber, W.J., "Effects of Self-Radiation Damage on the Leachability of Actinide-Host Phases," Advances in Ceramics. Vol. 8. Nuclear Waste Management, The American Ceramic Society (1984), pp. 715. 
WEBER, 1984--Weber, W.J., "Alpha-Irradiation Damage in $\mathrm{CeO}_{2}, \mathrm{UO}_{2}$, and $\mathrm{PuO}_{2}$," Radiation Effects 83, 145-156 (1984).

WEBER, 1985--Weber, W.J., Wald, J.W., and Matzke, Hj., "Self-Radiation Damage in $\mathrm{Gd}_{2} \mathrm{Ti}_{2} \mathrm{O}_{7}, "$ Mater. Letts. 3, 173-80 (1985).

WEBER, 1986--Weber, W.J., and Wald, J.W., "Effects of Self-Radiation Damage in Cm-Doped $\mathrm{Gd}_{2} \mathrm{Ti}_{2} \mathrm{O}_{7}$ and $\mathrm{CaZrTi}_{2} \mathrm{O}_{7}$," J. Nucl. Mater. 138, 196-209 (1986).

WEBER, 1992--Weber, W.J., Hess, N.J., and Maupin, G.D., "Amorphization in $\mathrm{Gd}_{2} \mathrm{Ti}_{2} \mathrm{O}_{7}$ and $\mathrm{CaZrTi}_{2} \mathrm{O}_{7}$ Irradiated with $3 \mathrm{MeV}$ Argon Ions," Nucl. Instr. and Meth. in Physics Research B65, 102-6 (1992).

WHITE, 1995--White, T.J, Ewing, R.C., Wang. L.M., Forrester, J.S., and Montross, C., "Temperature Dependence of Amorphization for Zirconolite and Perovskite Irradiated with $1 \mathrm{MeV}$ Krypton Ions," Scientific Basis for Nuclear Waste Management XVIII, Part 2, Mater. Res. Soc. Proceedings, vol. 353, 1413-20, T. Murakami and R.C. Ewing, eds. , Materials Research Society, Pittsburgh, PA (1995).

ZIEMNIAK, 1993--Ziemniak, S.E., Jones, M.E., and Combs, K.E.S., "Solubility Behavior of Titanium (IV) Oxide in Alkaline Media at Elevated Temperatures," J. Solution Chem., 22, 601-23 (1993). 
$$
\text { . }
$$

. 


\title{
Process and Equipment
}

\author{
Development for \\ Plant Deployment
}

Guy Armantrout 
Plant Implementation for Ceramics

- Based on process chemistry

- Must be practical on larger scale

- We would like to use existing equipment / technology

MOX industry is a major source of equipment and technology 


\section{Integrated Ceramic Flowsheet}

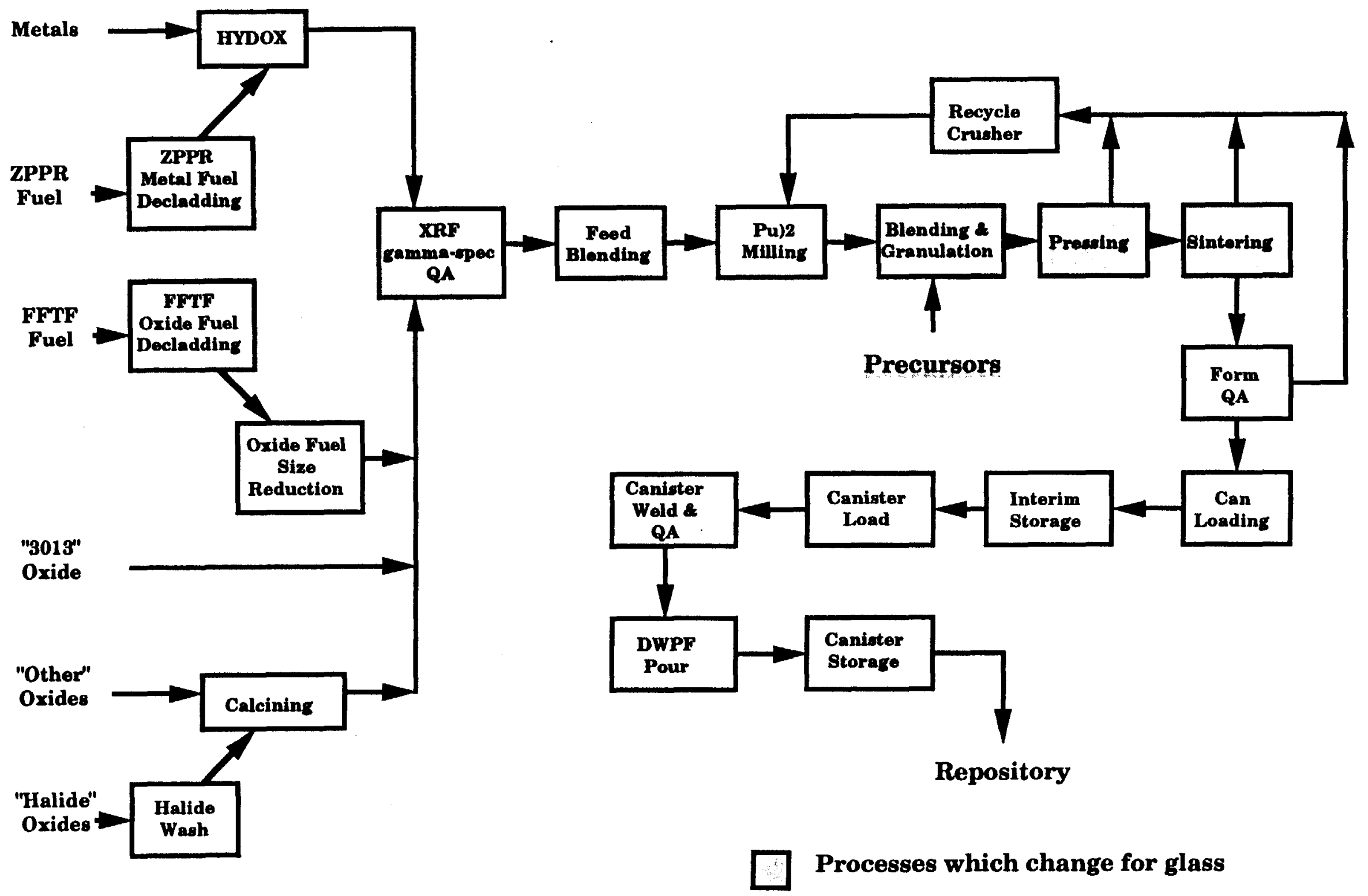




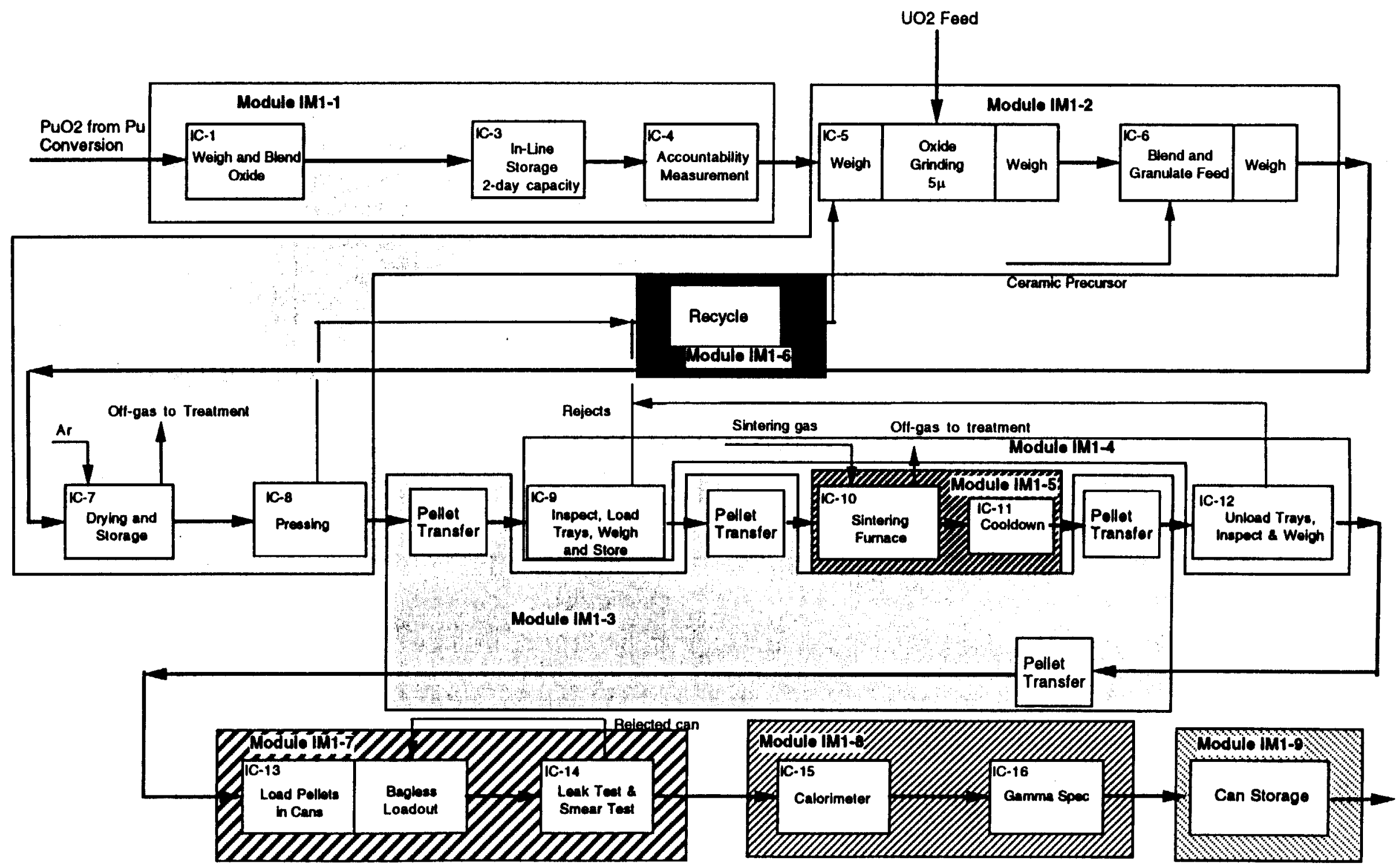


Ceramic feed preparation and blending are critical operations

- Milling of Pu and U necessary to assure reaction with precursors

- Solid diffusion time ${ }^{\wedge} 1 / 2$

- Intimate mixing is essential

- small particle size

- properly prepared precursors

- Granulation is needed for powder transfer to press, minimizing hold-up, and dust control 


\section{Milling is used to reduce particle size of all reactants}
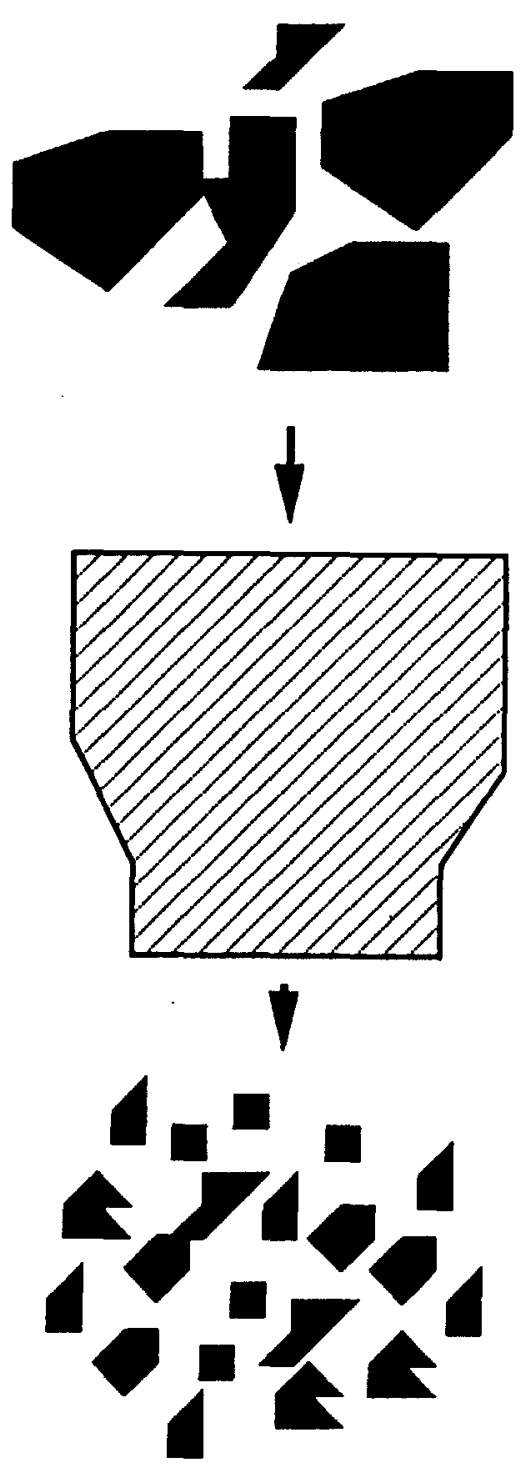

Feed:

$<100$ microns

Mill

(Attritor or Ball)

Product:

$<10$ microns 


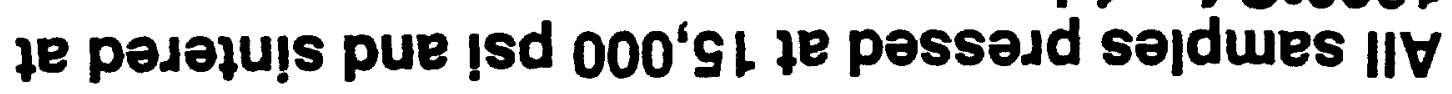

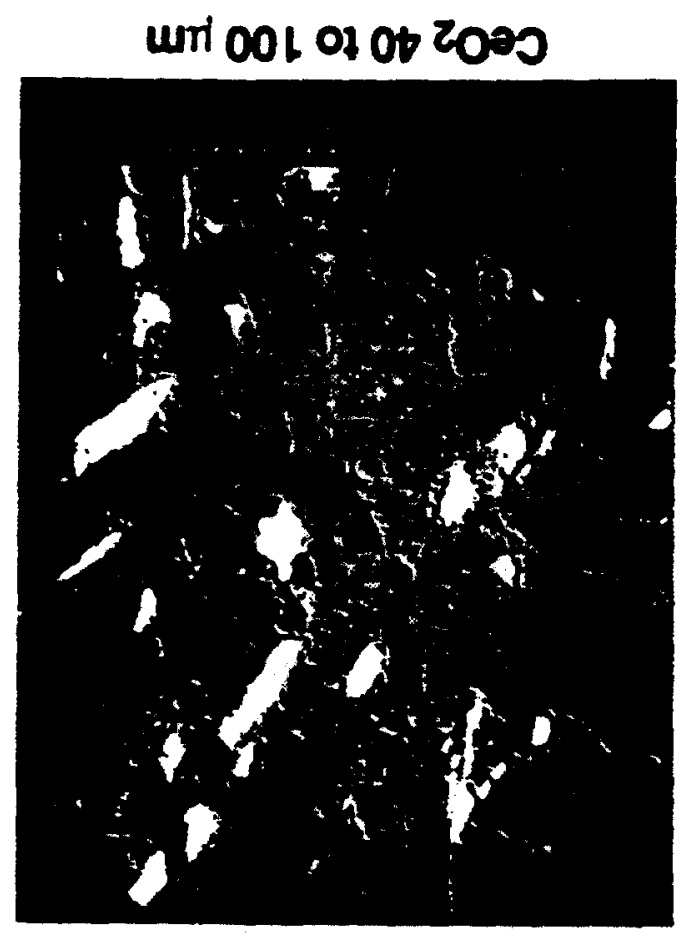

sse1 10 uml of 2005

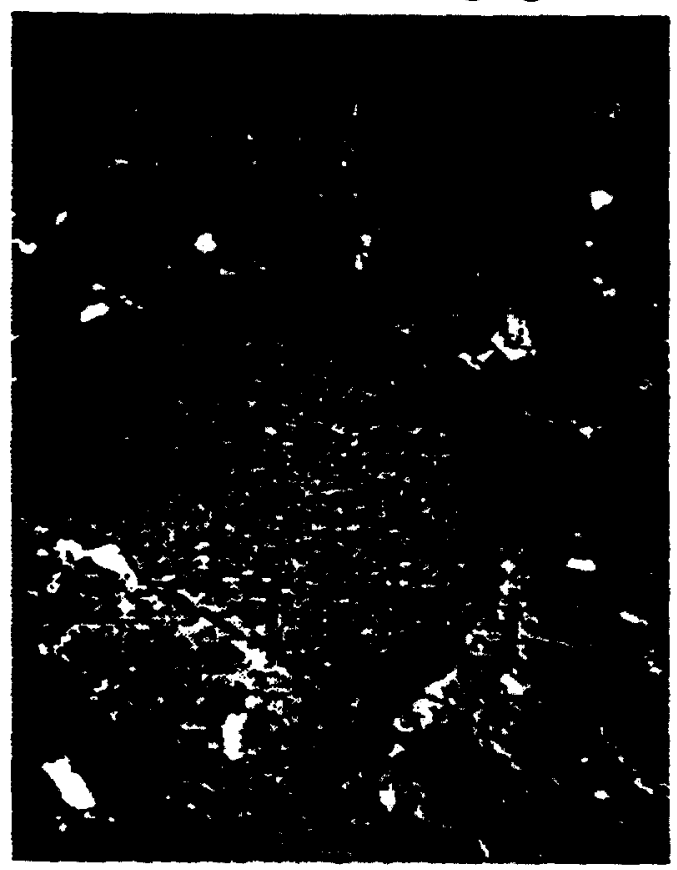

unil of 01012000

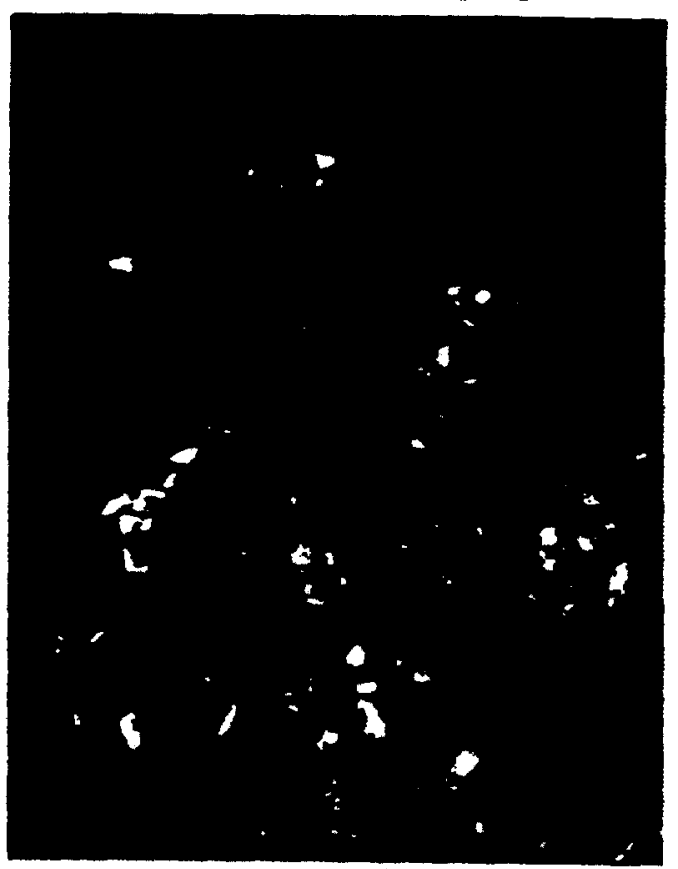

ssa| to uml g roas

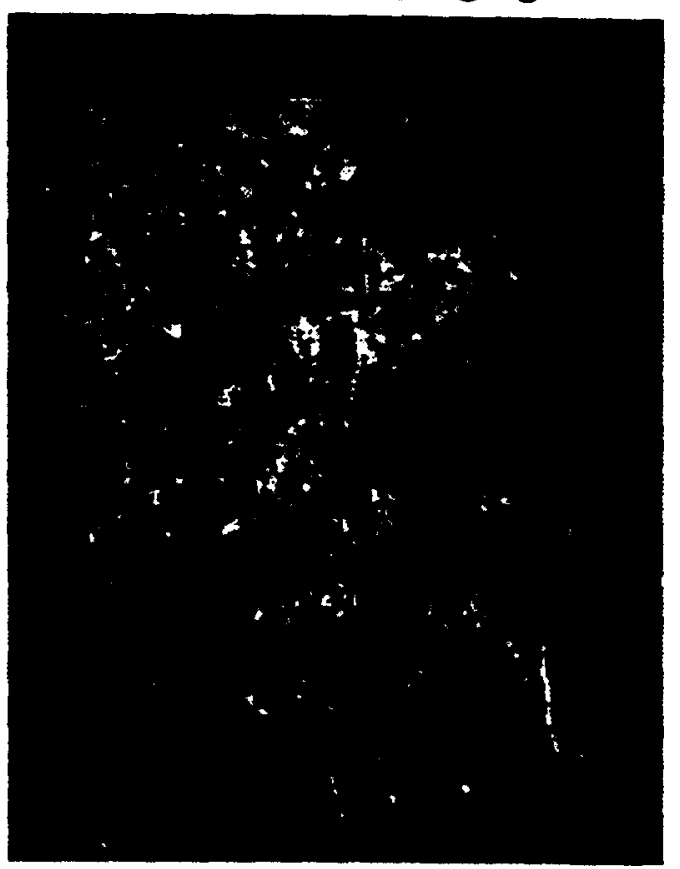

图

әz!

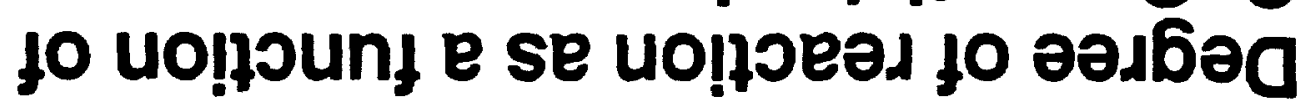


Blending is a very important operation

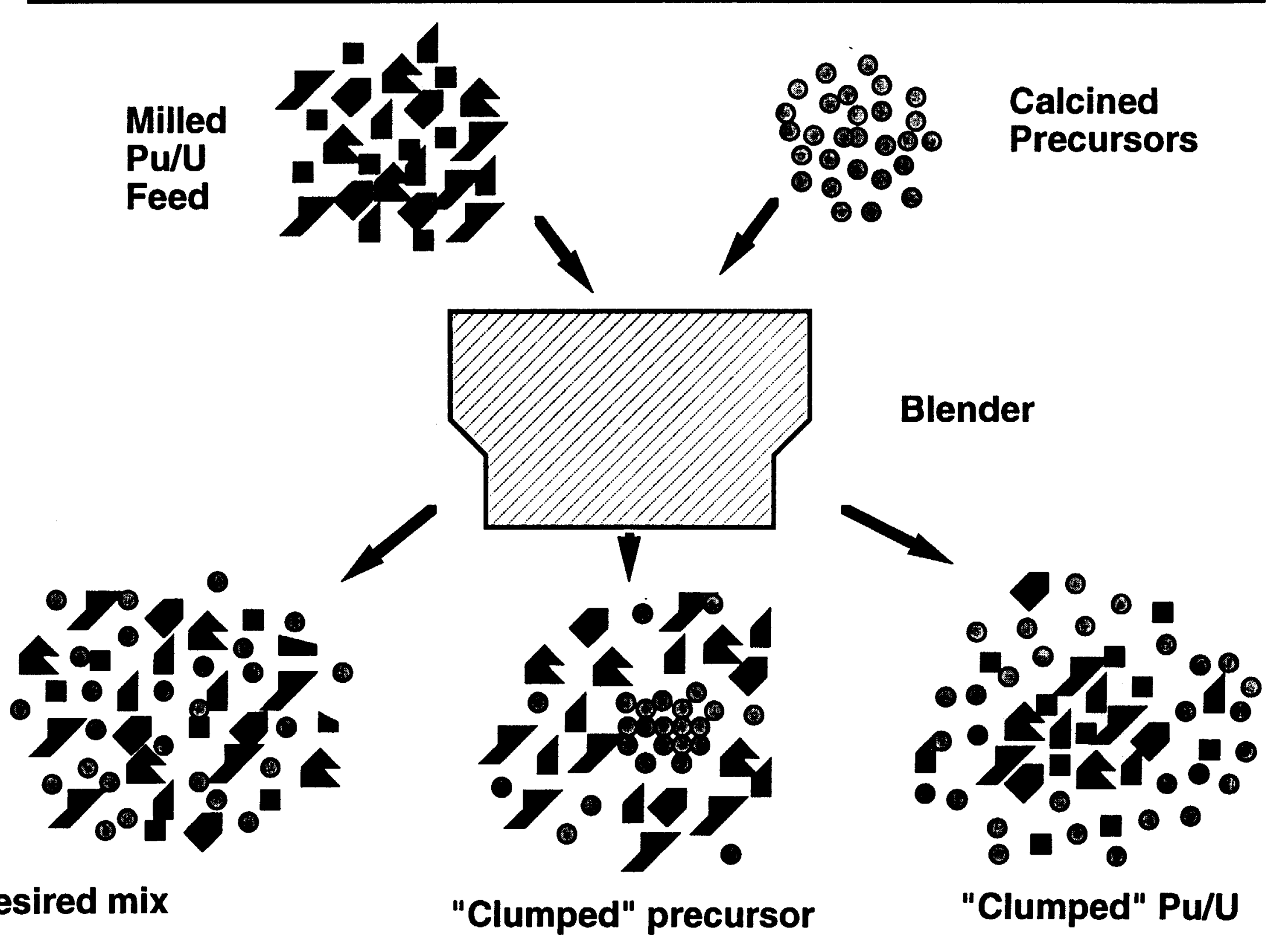


Undesirable mineral phases and unreacted regions can result from poor mixing following sintering
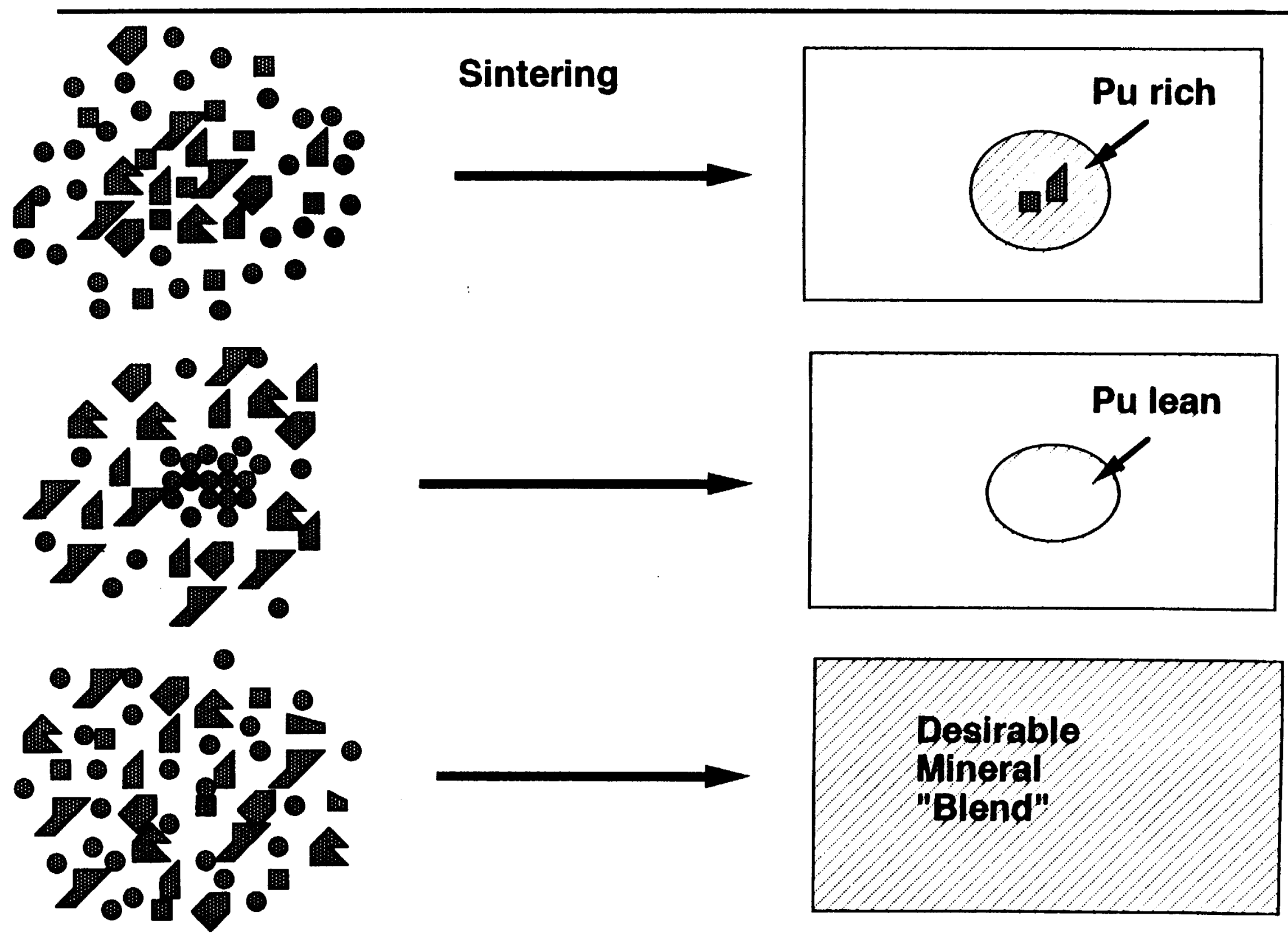


\section{Blending options:}

- Wet blending

- Complicates processing with water

- Dry blending with sufficient energy

- Ball milling

- Attritor milling

Preferred

- "V" blender (powder tumbling)

- insufficient mixing on micron scale 
Granulation is essential to control dusting and obtain a flowable powder

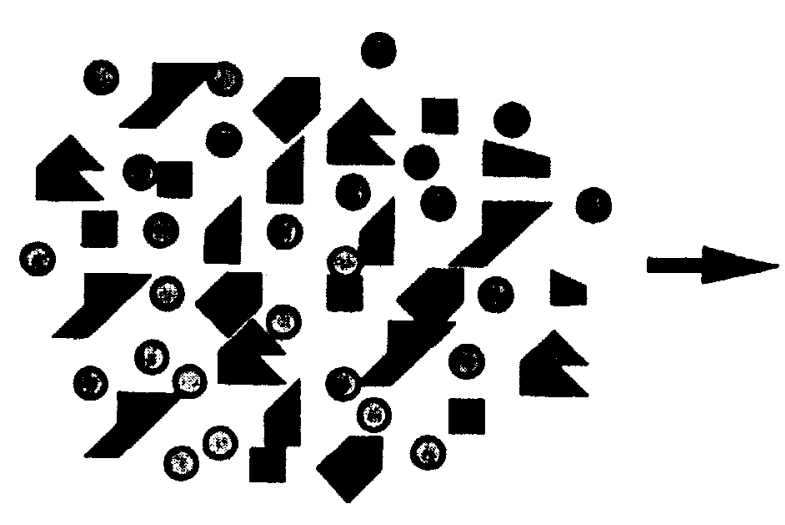

Blended feed

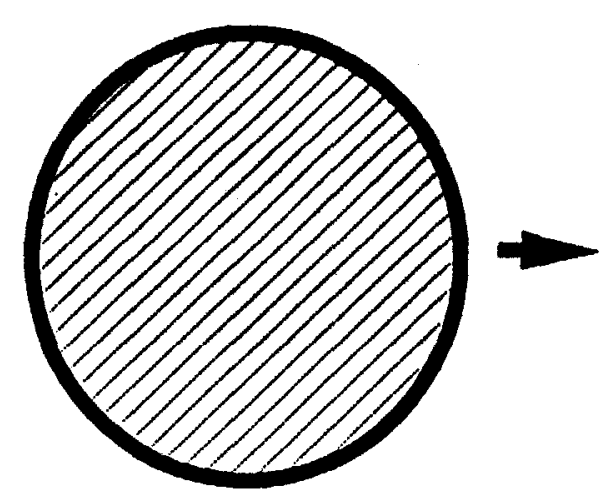

Granulator
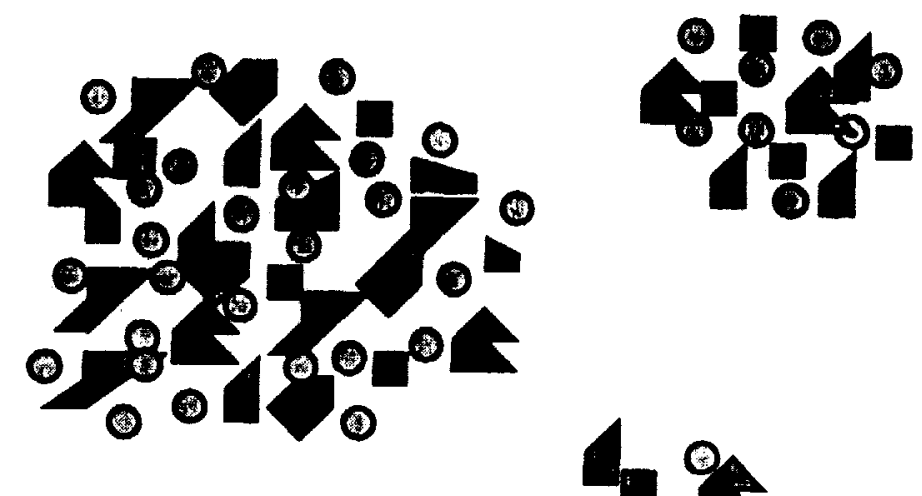

\author{
"Clumped" particles \\ of mixed blend
}


Glovebox 7806: Jetmill and blender

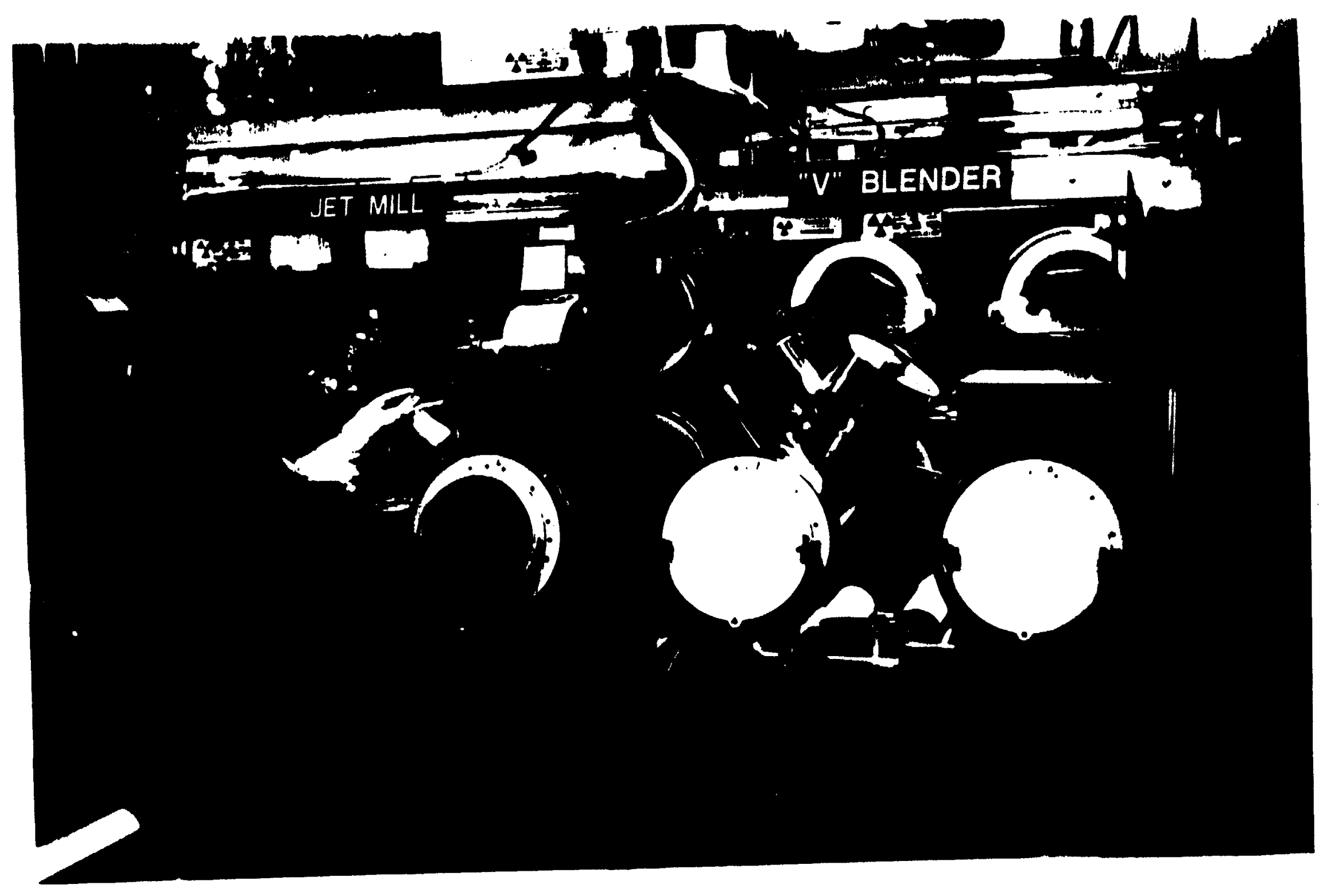




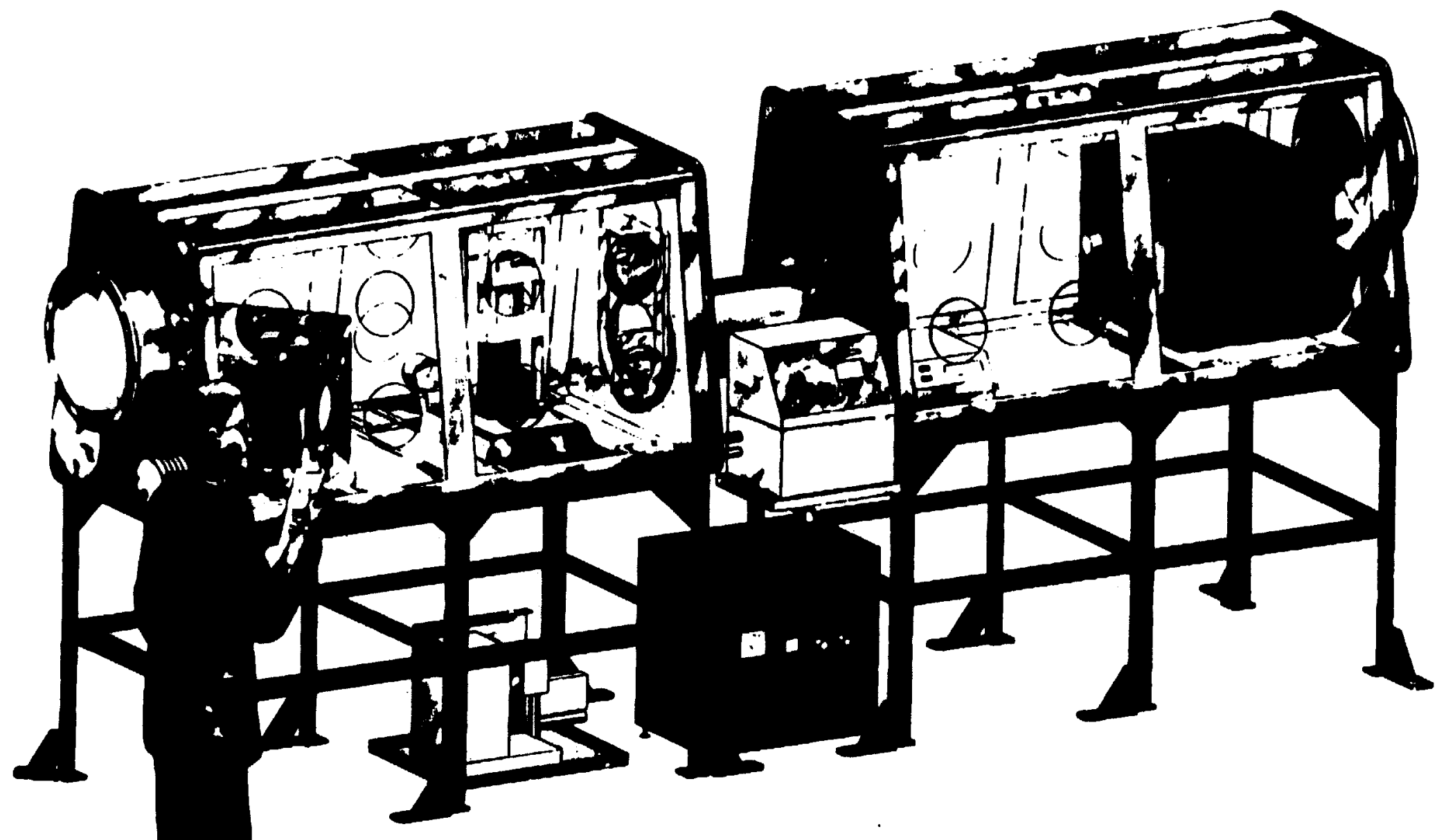


Proposed plant arrangement
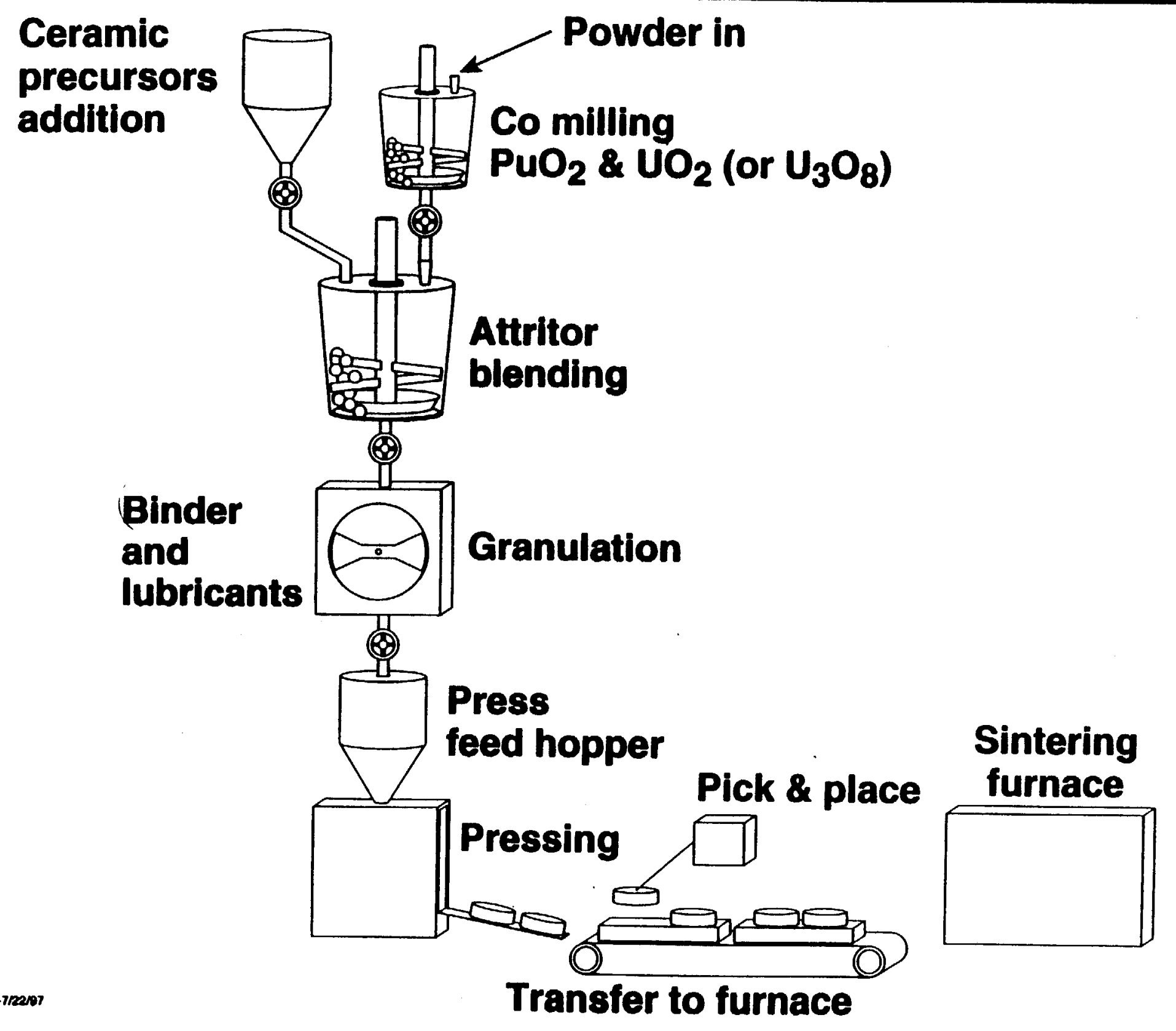


\title{
FORMULATION OF BASELINE CERAMIC AND FABRICATION OF SMALL PELLETS
}

\author{
Rich Van Konynenburg \\ Lawrence Livermore National Laboratory
}

U.S.-Russian Experts NATO Exchange Visit Meetings on Excess Weapons Pu

Ceramics Formulations and Characterizations

November 25, 1997 
Science

- Lawrence Livermore National Laboratory

- B. Ebbinghaus

- R. Ryerson

- J. Lawson
- R. VanKonynenburg

- P. Curtis
- W. Close

- R. Burns

- Australian Nuclear Science and Technology Organization

- E.R. Vance

- M.J. Hambley
- M.W.A. Stewart

- A. Brownscombe

- Westinghouse Savannah River Company
- J. Allender
- T. Rankin
- J. Congdon

- Argonne National Laboratory

- E. Buck

- U.C. Davis

- R. Putnam
- A. Bakel

- A. Navrotsky 


\section{Engineering}

- Lawrence Livermore National Laboratory

- J.C. Farmer

- W.A. Brummond - B.F. Hobson

- D.F. Gilbert - T.F. Churchill

- J.D. Lee

- D.V.Fix - D.W. Ahre 


\section{Baseline Case for the Ceramic Form}

- Composition (wt \%)

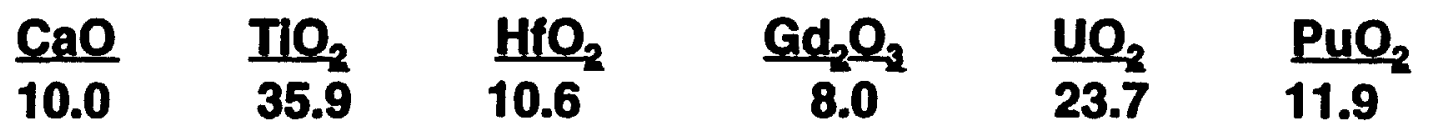

- Process

Feed

$\leq 20 \mu \mathrm{m} \mathrm{PuO}_{2}$

$\leq 20 \mu \mathrm{m} \mathrm{UO} \mathrm{O}_{2}\left(\right.$ or $\left.\mathrm{U}_{3} \mathrm{O}_{8}\right)$

- Product mineralogy

Phase Example Composition

Pyrochlore

Brannerite

Zirconolite

Rutile

Actinide oxide

Sillicate
Pressing

2 - 3 kpsi
Sintering

$1350+50 /-25^{\circ} \mathrm{C}$

4 hours

Argon (or air)

Relative Abundance (Vol \%)

Baseline Impurity Tests Processing Range

$\mathrm{Ca}(\mathrm{U}, \mathrm{Pu}) \mathrm{Tl}_{2} \mathrm{O}_{7}$

(U,Pu) $\mathrm{Tl}_{2} \mathrm{O}_{6}$ $\mathrm{CaHfT}_{2} \mathrm{O}_{7}$

$\mathrm{TiO}_{2}$

(U,Pu) $\mathrm{O}_{2}$

$\mathrm{CaO}-\mathrm{Al}_{2} \mathrm{O}_{3}-\mathrm{SIO}_{2}-\mathrm{TIO}_{2} \mathrm{O} \%$
$80 \%$

$12 \%$

$0 \%$

$8 \%$

$0.5 \%$

$$
62-90 \%
$$

$0-22 \%$

$0-25 \%$

$0-16 \%$

$004-0.6 \%$

$0-6 \%$
$>50 \%$

$0-50 \%$

$0-50 \%$

$0-20 \%$

$0-1 \%$

$0-6 \%$

Product density $=5.5 \mathrm{~g} / \mathrm{cm}^{3}$ (actual) $6.0 \mathrm{~g} / \mathrm{cm}^{3}$ (theoretical) 
Cerium is an excellent surrogate for $\mathrm{Pu}$ in ceramic formulation development

- Crystal radii are almost identical

- Pu4+: $0.100 \mathrm{~nm}(\mathrm{CN}=6)$

$-\mathrm{Ce}^{4+}: 0.101 \mathrm{~nm}(\mathrm{CN}=6)$

- Oxide stabilities are almost identical based on melting points

- $\mathrm{PuO}_{2}: 2660^{\circ} \mathrm{C}$

$-\mathrm{CeO}_{2}: 2600^{\circ} \mathrm{C}$

- Relative +4 to +3 stabilities are slightly different. For zirconolite sintered in argon at $1325^{\circ} \mathrm{C}$

- Pu oxidation state is $\mathbf{3 . 7 5}$

- Ce oxidation state is $\mathbf{3 . 5}$

Slight differences in relative +4 to +3 stabilities can be compensated by using more oxidizing conditions in the Ce samples 


\section{Particle size of UO2/PuO2 feed (ANSTO)}
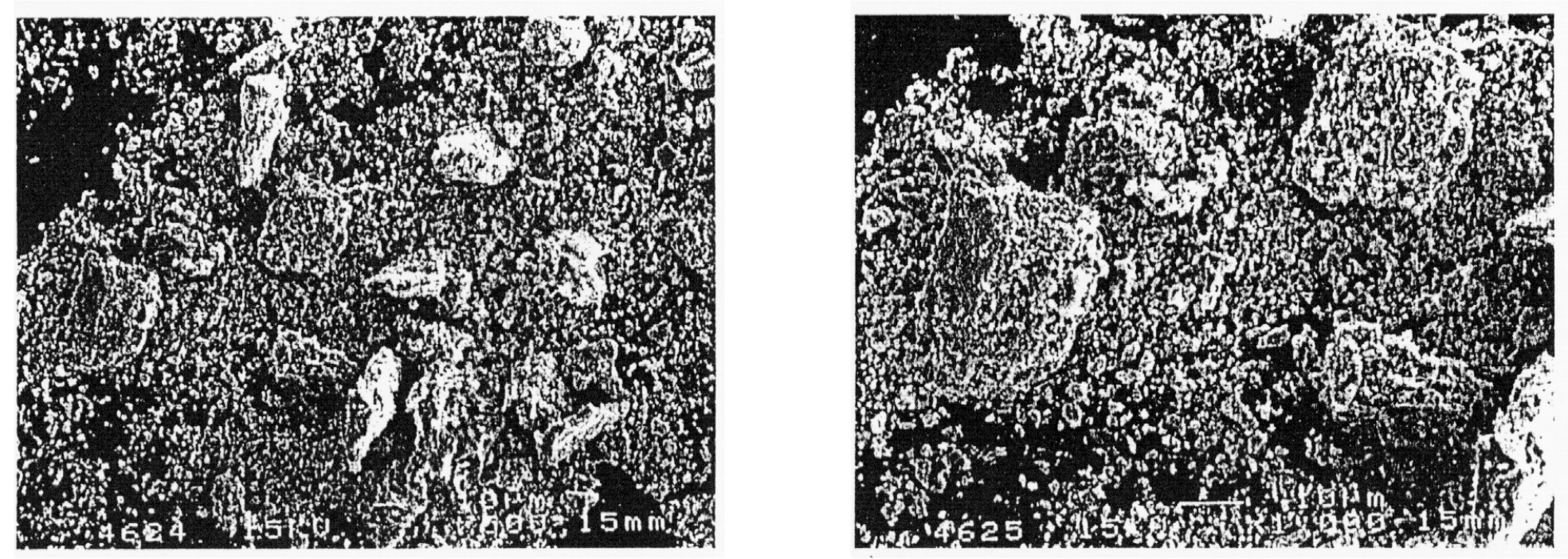

Task II

$\mathrm{M} \mathrm{c}$ os uc $\mathrm{u}$ e of calcined $(\mathrm{U}, \mathrm{Pu}) \mathrm{O}_{2}$ 


\section{Pu feed categories}

\section{Total Impurity $\quad$ Total Pu \\ Major Impurities Loading in Category}

$\begin{array}{llll}\text { 1. } \text { Typical impure Oxide: } & \mathrm{Al}, \mathrm{Si}, \mathrm{Mg}, \mathrm{Fe}, \mathrm{K}, \mathrm{Na}, \mathrm{W} & 2.8 & 5 \mathrm{MT}\end{array}$

$\begin{array}{llll}\text { 2. ZPPR Reactor Fuel: } & \text { Mo, Al } & 0.64 & 3 \text { MT }\end{array}$

3. Atypical Impure Metal: $\quad \mathrm{Ga}, \mathrm{Mg}, \mathrm{Al}, \mathrm{Ta} \quad 2.2 \quad 2$ MT

$\begin{array}{llll}\text { 4. } \text { Atypical clean Metal: } & \text { Ga, Zn } & 0.27 & 1 \text { MT }\end{array}$

5. U/Pu Oxides:

Mg, Mo, Fe

1.0

$1 \mathrm{MT}$

6. Pu Alloys:

Al, Mg

1.2

$1 \mathrm{MT}$

7. Average:

$\mathrm{Al}, \mathrm{Cl}, \mathrm{Ga}, \mathrm{Si}, \mathbf{M g}$

1.5

17 MT

8. Extreme impure Oxide:

Cl, W, K, Al, F

13.0

$1 \mathrm{MT}$

9. Simulates a glass test: $\quad \mathrm{Cl}, \mathrm{Ga}, \mathrm{W}, \mathrm{Al}, \mathrm{Mg}, \mathrm{K} \quad 5.1$ 


\section{Summary of Impurity Tests}

\begin{tabular}{|c|c|c|c|c|c|c|c|c|}
\hline $\begin{array}{c}\text { Test } \\
\text { Category }\end{array}$ & $\begin{array}{l}\text { Pu or } \\
\text { Ce }\end{array}$ & Site & $\begin{array}{l}\text { Impurity } \\
\text { Loading }\end{array}$ & Pyrochlore $^{a}$ & Brannerite & Zirconolite $^{a}$ & $\begin{array}{l}\text { Rutile/ } \\
\text { Silicate }^{b}\end{array}$ & $\begin{array}{c}\text { Actinide } \\
\text { Oxide }\end{array}$ \\
\hline baseline-dry & $\mathbf{P u}$ & ANSTO & $0 \%$ & $78 \%$ & $14 \%$ & $0 \%$ & $8 \%$ & $0.6 \%$ \\
\hline baseline-wet & Pu & ANSTO & $0 \%$ & $78 \%$ & $14 \%$ & $0 \%$ & $8 \%$ & $0.5 \%$ \\
\hline baseline-wet & $\mathrm{Ce}$ & LLNL & $0 \%$ & $86 \%$ & $8 \%$ & $0 \%$ & $6 \%$ & $0 \%$ \\
\hline$\# 1$ & $\mathrm{Ce}$ & SRS & $2.8 \%$ & $80 \%$ & $3 \%$ & $2 \%$ & $15 \%$ & $0 \%$ \\
\hline$\# 2$ & $\mathbf{P u}$ & LLNL & $0.64 \%$ & $68 \%$ & $12 \%$ & $17 \%$ & $3 \%$ & $0.4 \%$ \\
\hline \#3 & Pu & ANSTO & $2.2 \%$ & $77 \%$ & $13 \%$ & $6 \%$ & $4 \%$ & $0.04 \%$ \\
\hline$\# 4$ & $\mathbf{P u}$ & LLNL & $0.27 \%$ & $73 \%$ & $8 \%$ & $17 \%$ & $2 \%$ & $0.2 \%$ \\
\hline$\# 5$ & $\mathbf{P u}$ & ANSTO & $1.0 \%$ & $85 \%$ & $7 \%$ & $1 \%$ & $7 \%$ & $0.2 \%$ \\
\hline$\# 6$ & $\mathrm{Ce}$ & SRS & $1.2 \%$ & $62 \%$ & $22 \%$ & $5 \%$ & $11 \%$ & $0.05 \%$ \\
\hline$\# 7$ & $\mathbf{P u}$ & LLNLANSTO & $1.5 \%$ & $89 \%$ & $6 \%$ & $0 \%$ & $5 \%$ & $0.3 \%$ \\
\hline$\# 8$ & $\mathbf{P u}$ & LLNLAANSTO & $13.0 \%$ & $75 \%$ & $0 \%$ & $19 \%$ & $6 \%$ & $0.2 \%$ \\
\hline$\# 9$ & $\mathbf{P u}$ & LLNL & $5.1 \%$ & $70 \%$ & $2 \%$ & $24 \%$ & $3 \%$ & $0.04 \%$ \\
\hline
\end{tabular}

All compositions are given in volume percent.

APyrochlore and zirconolite can be difficult to distinguish in SEM Images.

bRutile and silicate are difficult to distinguish in SEM images. 


\section{Impurity Partitioning Coefficients}

Table 1. Partitioning coefficients of impurities in the main ceramic phases.

\begin{tabular}{|l|l|l|}
\hline & & \\
\hline Element & Zirconolite/Pyrochlore & Brannerite/Pyrochlore \\
\hline $\mathrm{Al}$ & 16.2 & 2.3 \\
\hline $\mathrm{Cr}$ & $>4$ &.-- \\
\hline $\mathrm{Fe}$ & 4 & 1 \\
\hline $\mathrm{Ga}$ & $>30$ & --- \\
\hline $\mathrm{Mg}$ & 3.1 & $<0.1$ \\
\hline $\mathrm{Mo}$ & 0.10 & 0.20 \\
\hline $\mathrm{Na}$ & 1.0 & 0.2 \\
\hline $\mathrm{Ni}$ & 1 & 2 \\
\hline $\mathrm{Ta}$ & $<0.1$ & $<0.1$ \\
\hline $\mathrm{W}$ & $<0.1$ & --- \\
\hline $\mathrm{Zn}$ & 4 & 5 \\
\hline
\end{tabular}

The partitioning coefficient is given as the mole fraction of element in the phase of interest divided by the mole fraction of the element in pyrochlore.

$\mathrm{P}_{\mathrm{A}}=\mathrm{X}_{\mathrm{A}}$ (zirconolite or brannerite) $/ \mathrm{X}_{\mathrm{A}}$ (pyrochlore) 


\title{
Dissolution Testing
}

\author{
William Bourcier \\ Pihong Zhao \\ Sue Martin \\ Brad Esser \\ Suzie Hulsey
}

November 25, 1997.

for

U.S-Russian Experts NATO Exchange Visit Meetings on

Excess Weapons Pu Ceramics Formulations and

Characterizations. 


\section{Work in Progress at LLNL}

1. Synthesis of single phase ceramics for testing:

Pyrochlore $\mathrm{CaPuTi}_{2} \mathrm{O}_{7} \quad(\mathrm{Ca}, \mathrm{Gd})(\mathrm{Pu}, \mathrm{U}, \mathrm{Gd}, \mathrm{Hf}) \mathrm{Ti}_{2} \mathrm{O}_{7}$

Zirconolite $\mathrm{CaZrTi}_{2} \mathrm{O}_{7}$

Brannerite $\mathrm{PuTi}_{2} \mathrm{O}_{6}$

2. Radioactive SPFT tests:

Ce-U pyrochlore-based ceramic at $25^{\circ} \mathrm{C}$ $\mathrm{Pu}-\mathrm{U}$ pyrochlore-based ceramic at $25^{\circ} \mathrm{C}$

3. Non-radioactive SPFT tests at high temperatures (up to $250^{\circ} \mathrm{C}$ ).

4. Model development. 


\section{Types of Durability Tests}

MCC-1 - One cm diameter disks polished to a 240-grit finish in a stainless steel vessel with $18 \mathrm{~g}$ deionized water $\left(10 \mathrm{~m}^{-1}\right)$ for three days at $90^{\circ} \mathrm{C} . A N L$

Product Consistency Test (PCT) - crushed material (-100+200 mesh) and deionized water in stainless steel vessels. ANL

PCT-A in which one gram of test material reacts with $10 \mathrm{~g}$ of DI (S/V of $1200 \mathrm{~m}^{-1}$ ) for 7 days at $90^{\circ} \mathrm{C}$. $A N L$

PCT-B in which five grams of test material reacts with $5 \mathrm{~g}$ of DI water $(\mathrm{S} / \mathrm{V}$ of $12,000 \mathrm{~m}-1)$ for various times (28-182 days) at $90^{\circ} \mathrm{C}$. $A N L$

Single Pass Flow Through (SPFT) - solution of fixed composition flows through powdered sample, $25-250^{\circ} \mathrm{C}$ reacts for days to weeks. LLNL, PNNL.

Pressurized Unsaturated Flow Test (PNNL's PUF test) - Unsaturated flow through porous medium composed of waste form and other materials. PNNL

Unsaturated test (ANL drip test) - Drop of solution periodically drips on monolith of material. $A N L$

Vapor hydration test - material reacted in hot humid environment. ANL 


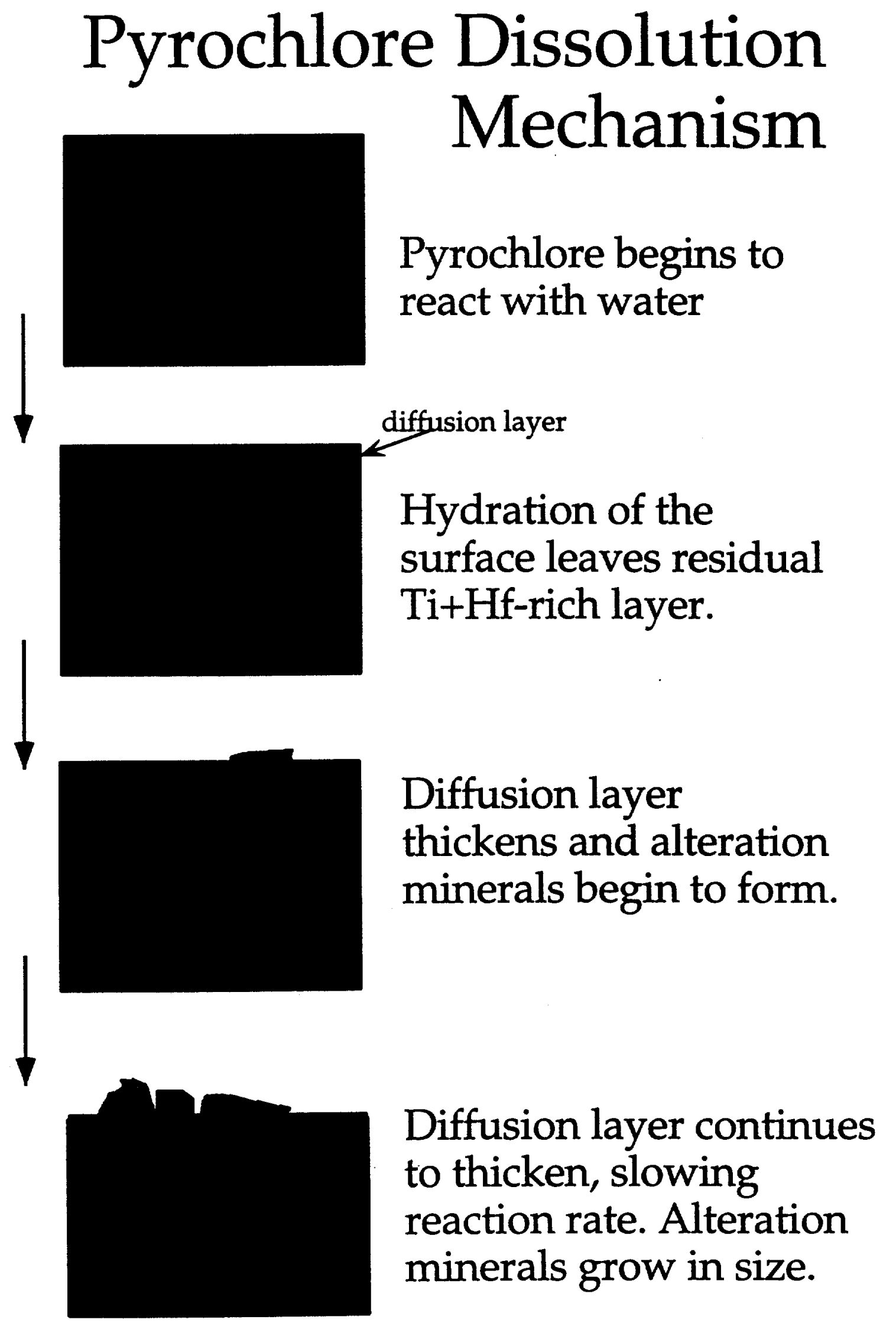




\section{Rate Equation for Pyrochlore Dissolution}

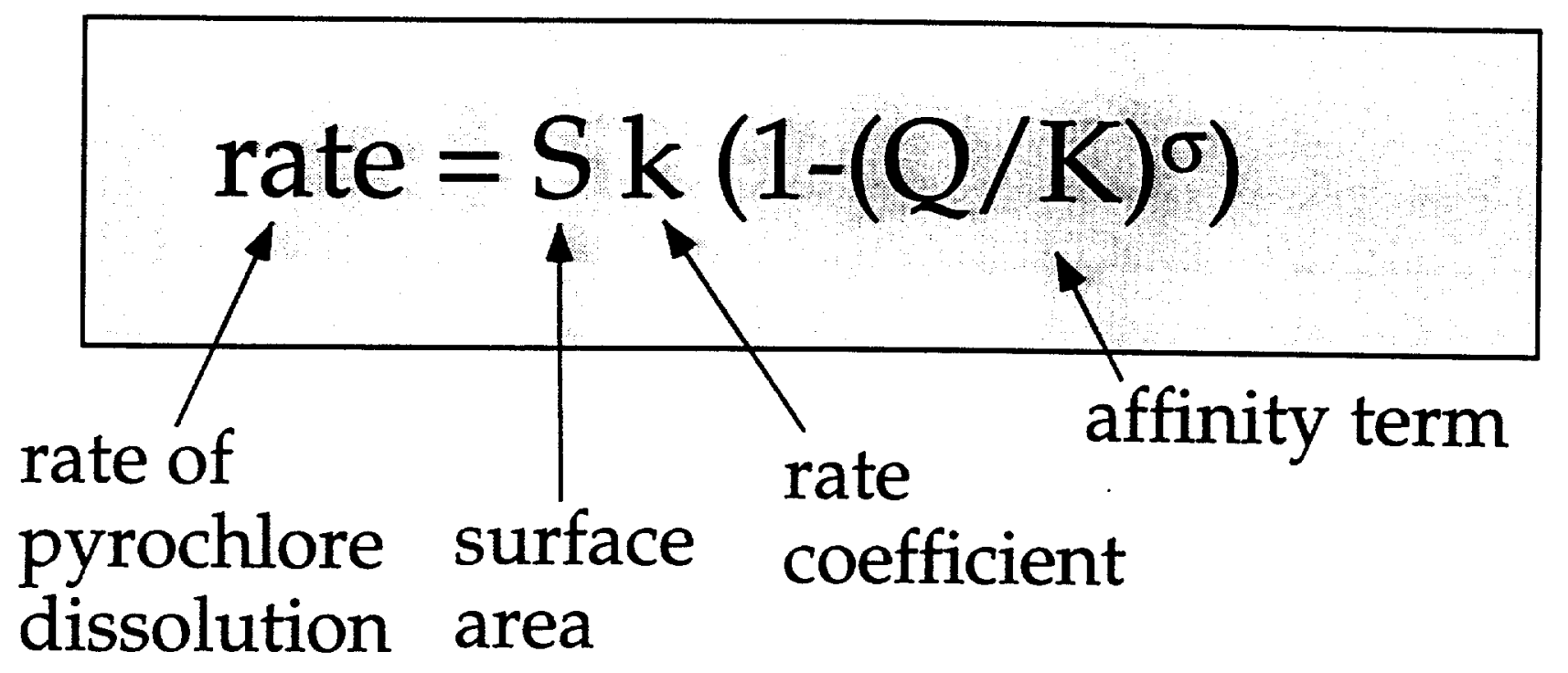

$Q$ - activity (concentration) product for pyrochlore

$\mathrm{K}$ - solubility product for pyrochlore

$\sigma$ - average stoichiometric number for rate-limiting reaction 


\section{Pyrochlore Dissolution Reaction}

Pu-endmember:

$\mathrm{CaPuTi} \mathrm{O}_{7}+3 \mathrm{H}^{+}+1 / 4 \mathrm{O}_{2(\mathrm{~g})}+5 / 2 \mathrm{H}_{2} \mathrm{O}=$ $\mathrm{Ca}^{2+}+\mathrm{PuO}_{2}^{+}+2 \mathrm{Ti}(\mathrm{OH})_{4(\mathrm{aq})}$

$\mathrm{K}=\mathrm{a}_{\mathrm{Ca}++} \mathrm{a}_{\mathrm{PuO} 2+} \mathrm{a}_{\mathrm{Ti}(\mathrm{OH}) 4} / \mathrm{a}_{\mathrm{H}+}^{3} \mathrm{f}^{1 / 4}{ }_{\mathrm{O} 2(\mathrm{~g})}$ $\Delta \mathrm{G}=-\mathrm{RT} \ln \mathrm{K}$

Solid solution with neutron absorbers:

$\mathrm{Ca}(\mathrm{Pu}, \mathrm{Gd}, \mathrm{Hf}, \mathrm{U}) \mathrm{Ti}_{2} \mathrm{O}_{7}+\mathrm{H}^{+}+\mathrm{O}_{2(\mathrm{~g})}+\mathrm{H}_{2} \mathrm{O}$

$\mathrm{Ca}^{2+}+1 / 4 \mathrm{PuO}_{2}^{+}+1 / 4 \mathrm{Gd}(\mathrm{OH})_{3(\mathrm{aq})}+$ $1 / 4 \mathrm{Hf}(\mathrm{OH})_{4(\mathrm{aq})}+1 / 4 \mathrm{UO}_{2}{ }^{2+}+2 \mathrm{Ti}(\mathrm{OH})_{4(\mathrm{aq})}$

Similar relationships as above.

Calorimetry of pure phases and solid solutions will provide $\Delta \mathrm{G}$ values which can be used to calculate solubilities. We will then know the saturation states of our test solutions. 


\section{Conditions for SPFT Tests of Pyrochlore Ceramic}

\section{Ceramic Compositions (wt\%)}

$\begin{array}{lcc}\text { Oxide } & \mathrm{Ce}-\mathrm{U} \text { formulation } & \mathrm{Pu}-\mathrm{U} \text { formulation } \\ \mathrm{CaO} & 13 & 10\end{array}$

$\mathrm{UO} 2$

$\mathrm{CeO} 2$

$\mathrm{PuO} 2$

$\mathrm{TiO} 2$

$\mathrm{HfO} 2$

$\mathrm{Gd} 2 \mathrm{O} 3$

$\mathrm{Ga}+\mathrm{Mg}+\mathrm{Zn}$
30

10

36

12

$--$

$-$
24

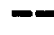

12

36

11

8

0.6

Test Conditions:

Leachate buffer solutions:

$\mathrm{pH} 2 \mathrm{HCl} \quad 0.01$ molal

pH $4 \quad$ o-phthalic acid/HCl $\quad 0.005$ molal

pH 6 o-phthalic acid/ $/ \mathrm{NaOH}$

pH $8 \quad$ Boric acid/ $/ \mathrm{HCl}$

$\mathrm{pH} 8^{*}$

$\mathrm{pH} 8^{*}$

$\mathrm{pH} 10^{*}$

$\mathrm{pH} 12^{*}$

$*$ in preparation
Sodium bicarbonate

Sodium phosphate

Sodium carbonate

$\mathrm{NaOH}$
0.005 molal

0.005 molal

0.005 molal

0.005 molal

0.01 molal
0.005 molal

$\rightarrow 1$ gram 45-75 micron powder

$\rightarrow 0.45$ micron filters

-> flow rates of $15-50 \mathrm{ml} /$ day 


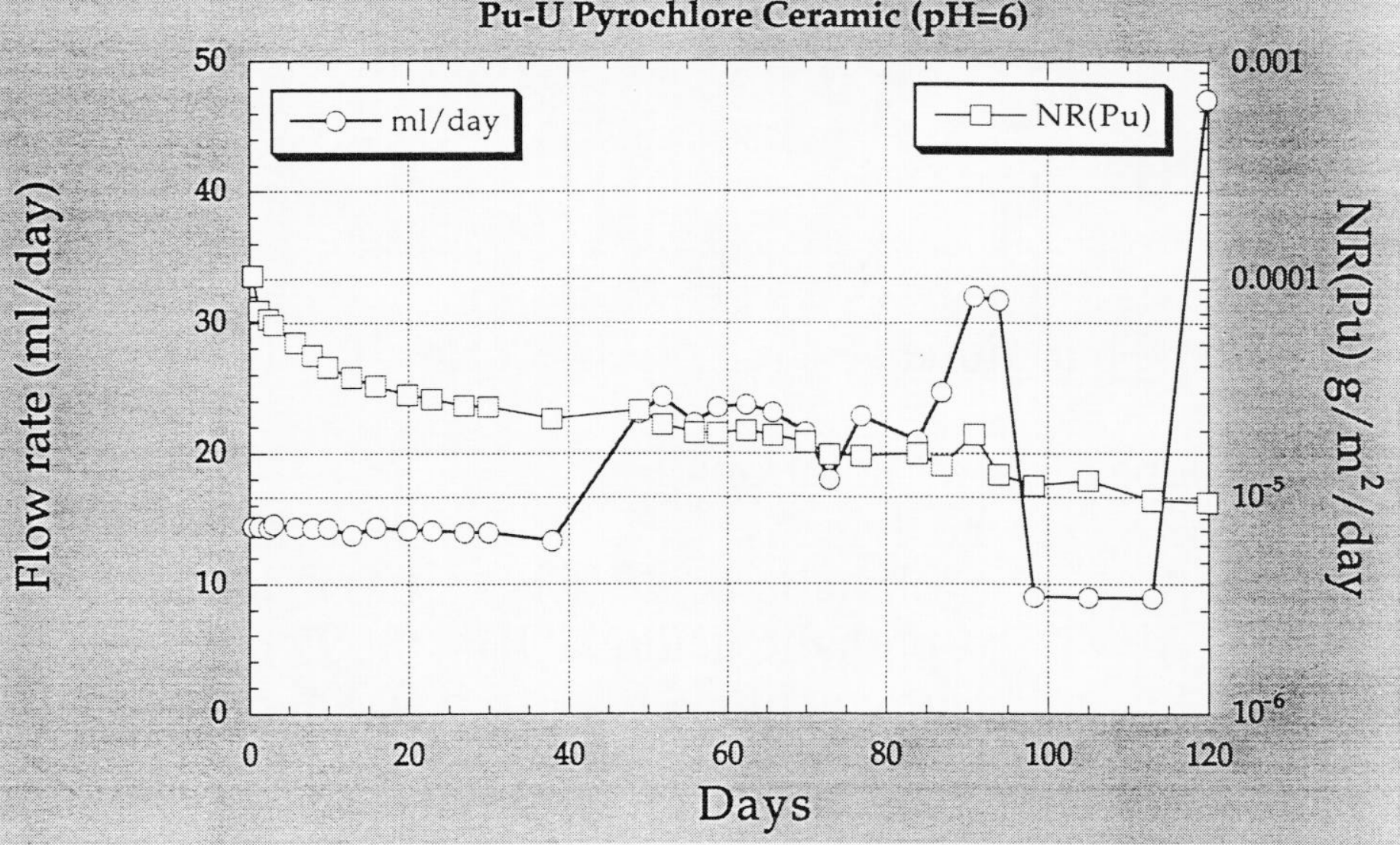




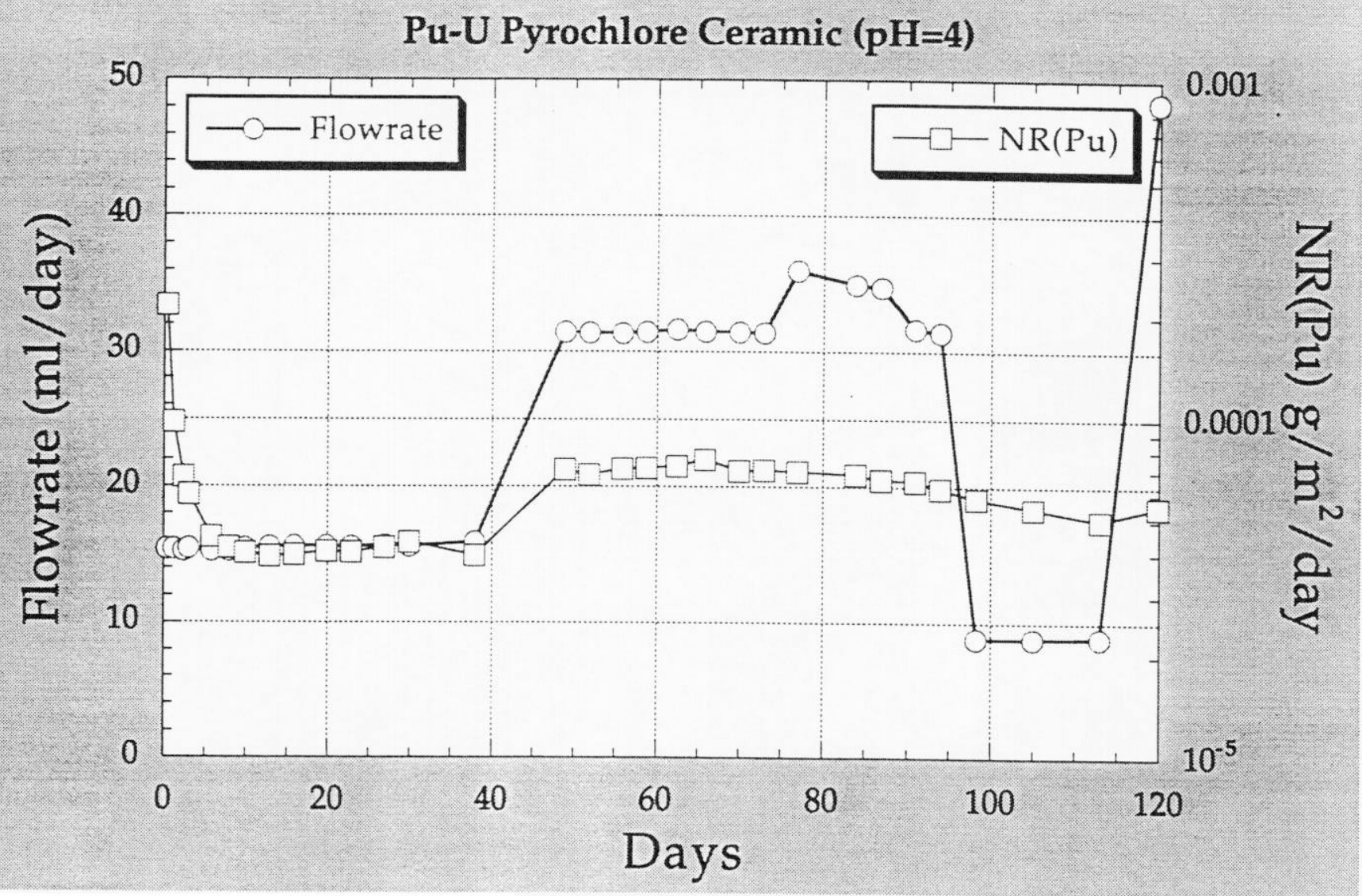




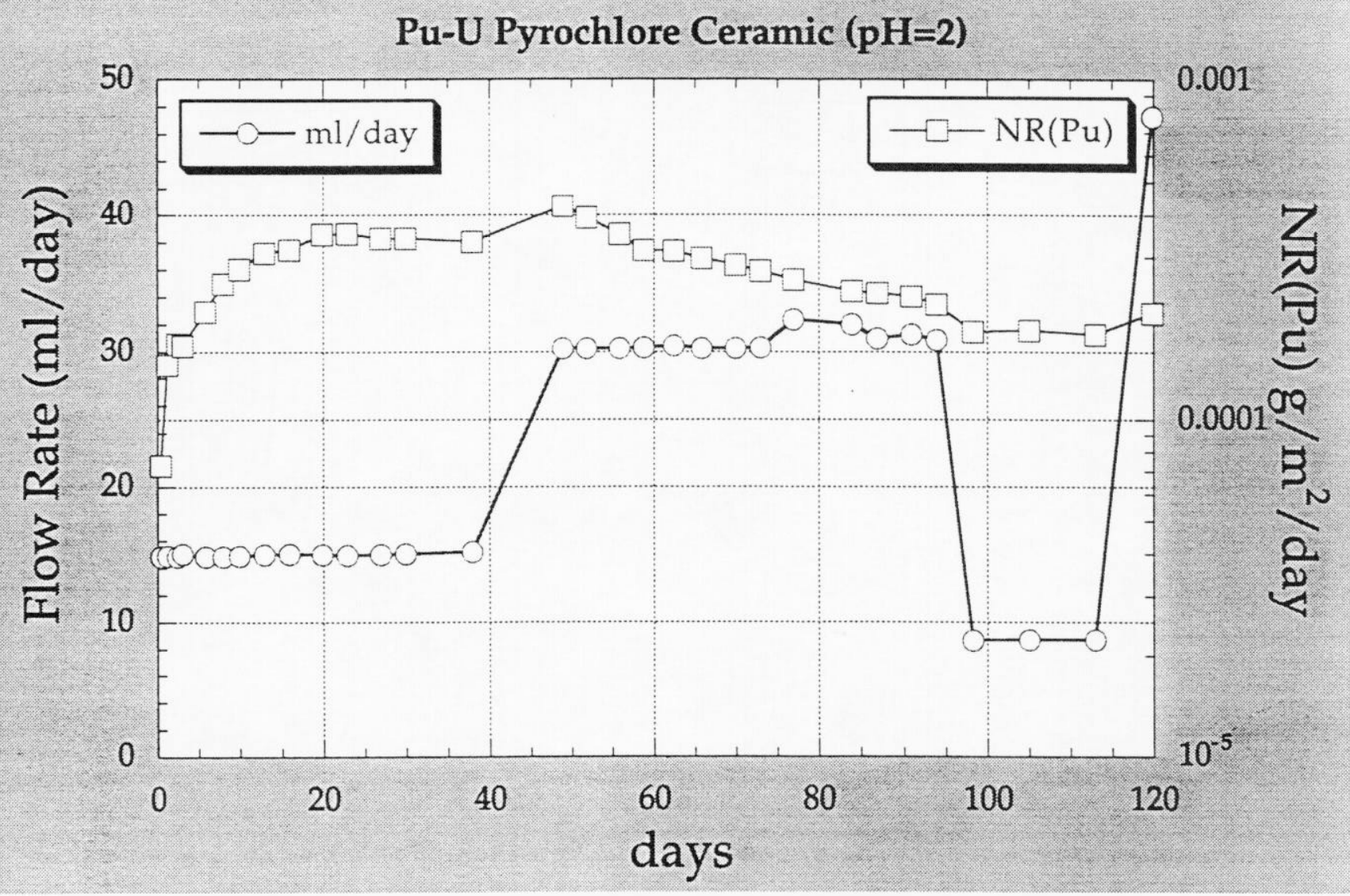




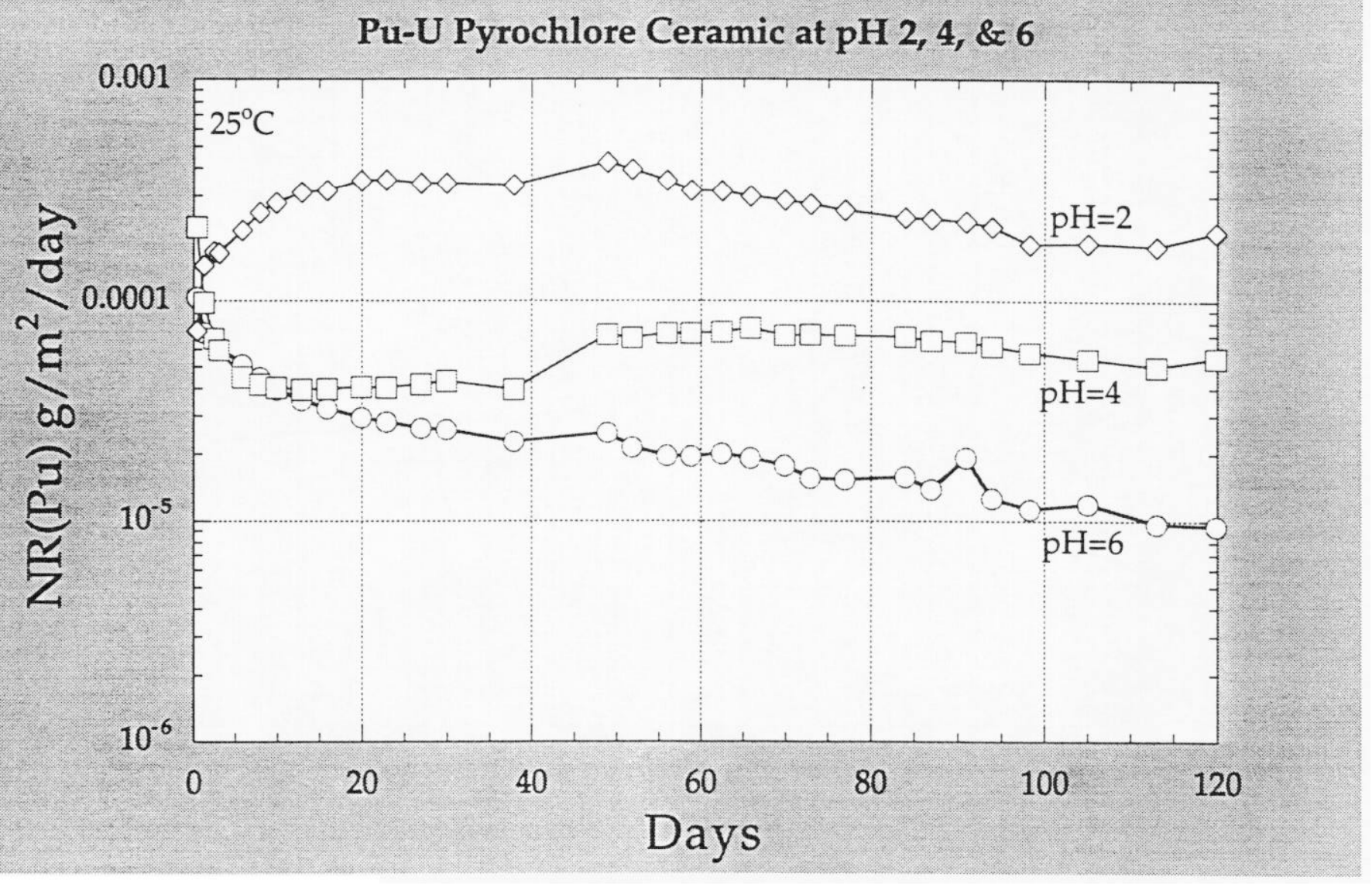




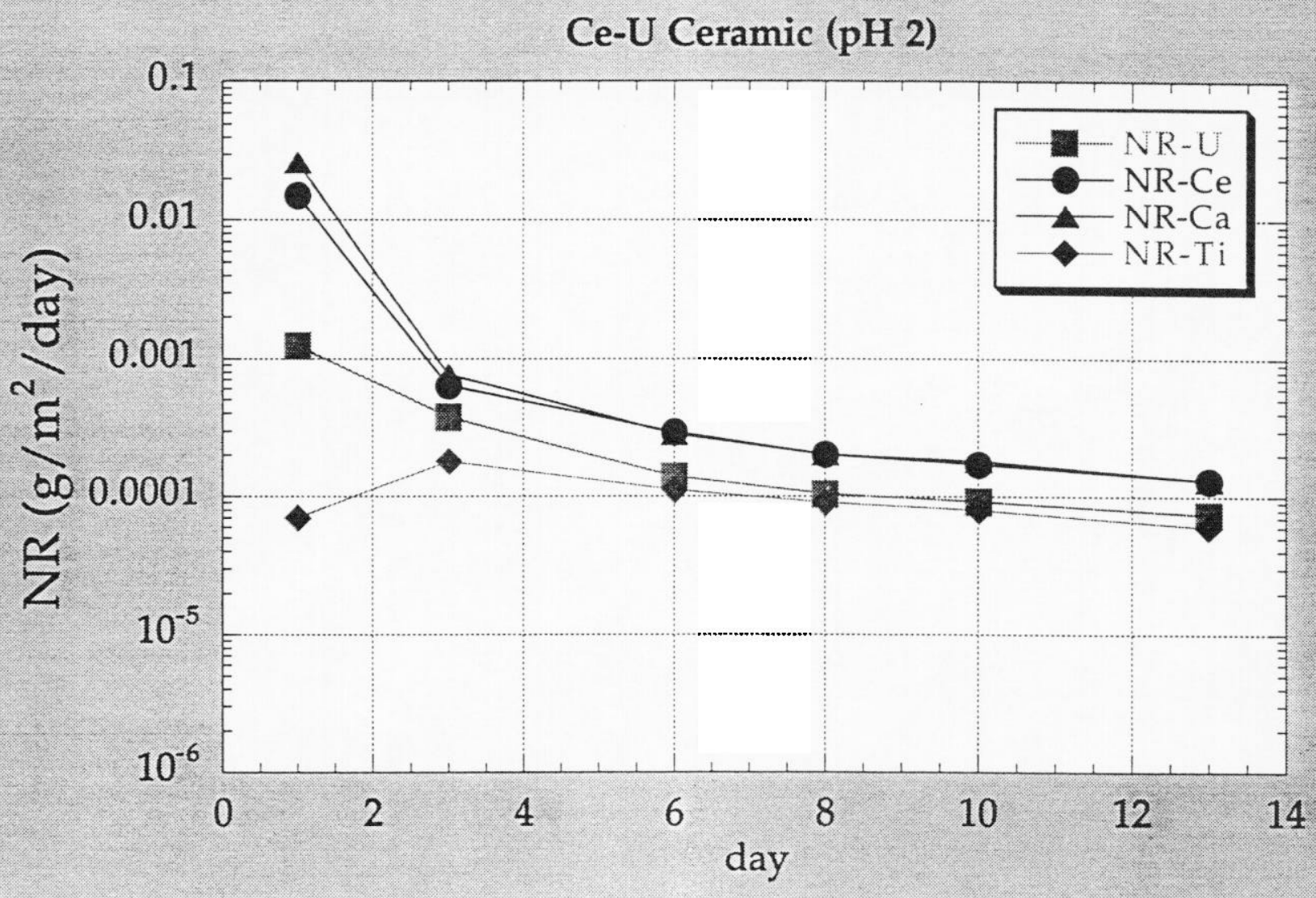




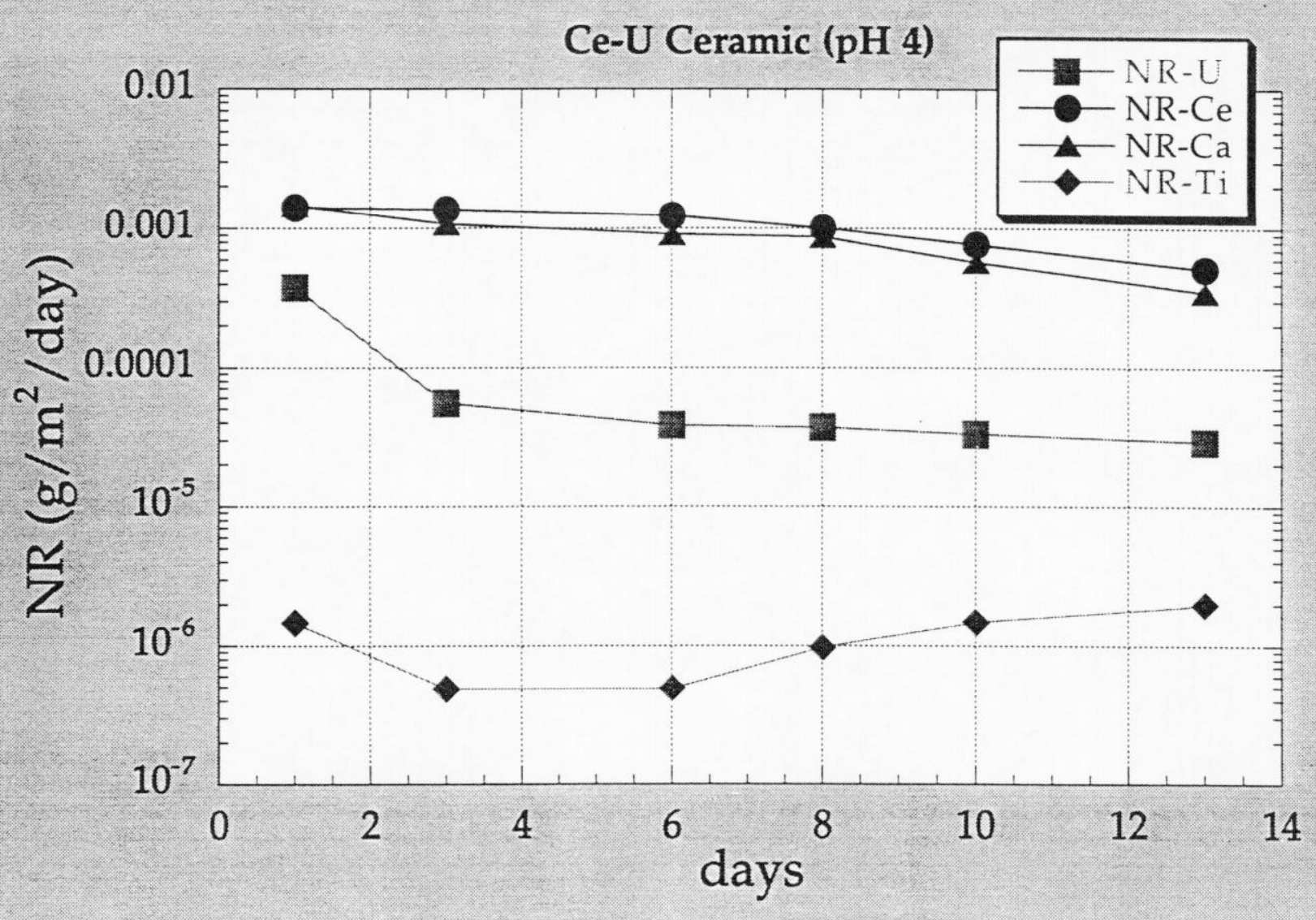




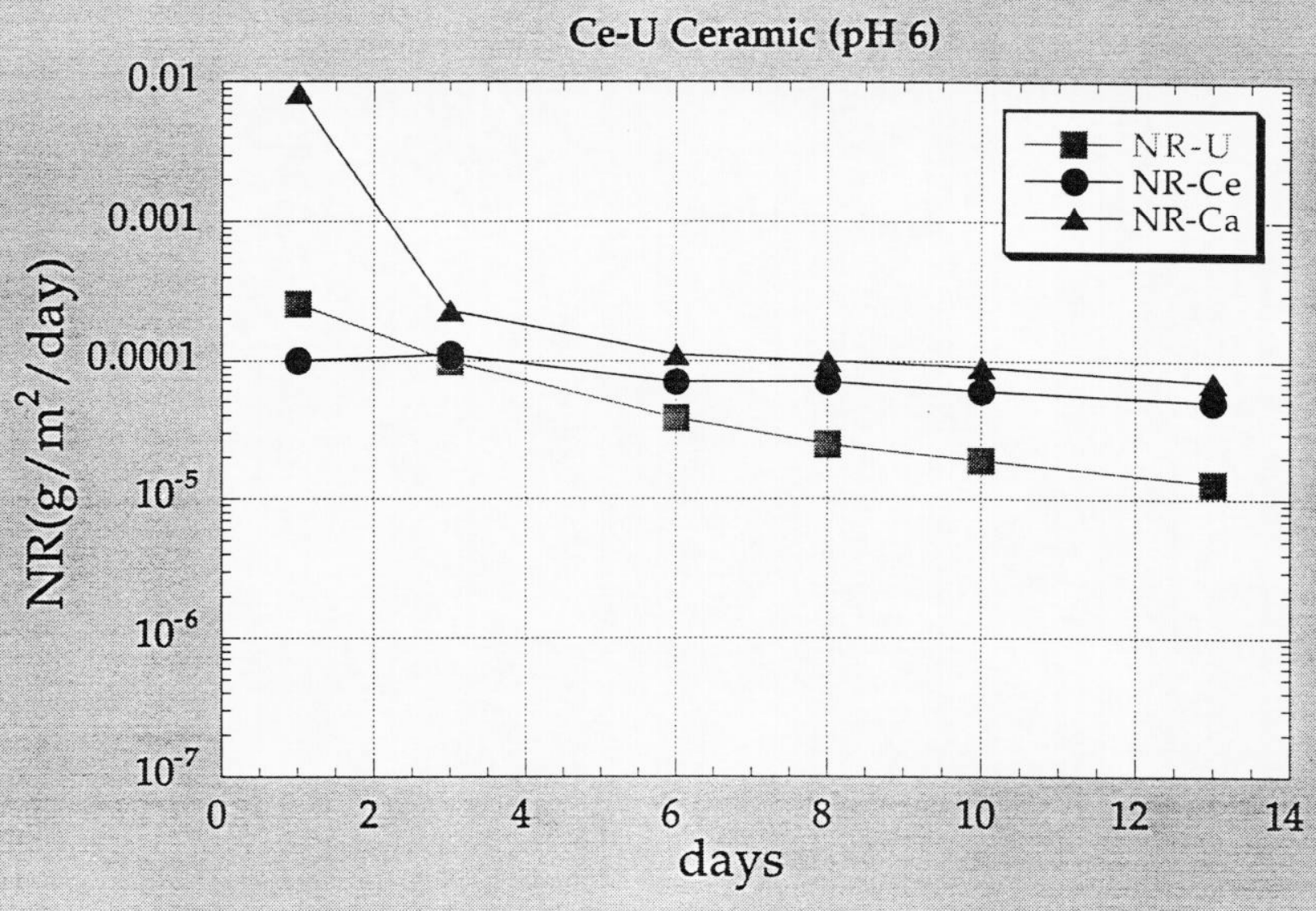




\section{Ce-U Ceramic (pH 8)}

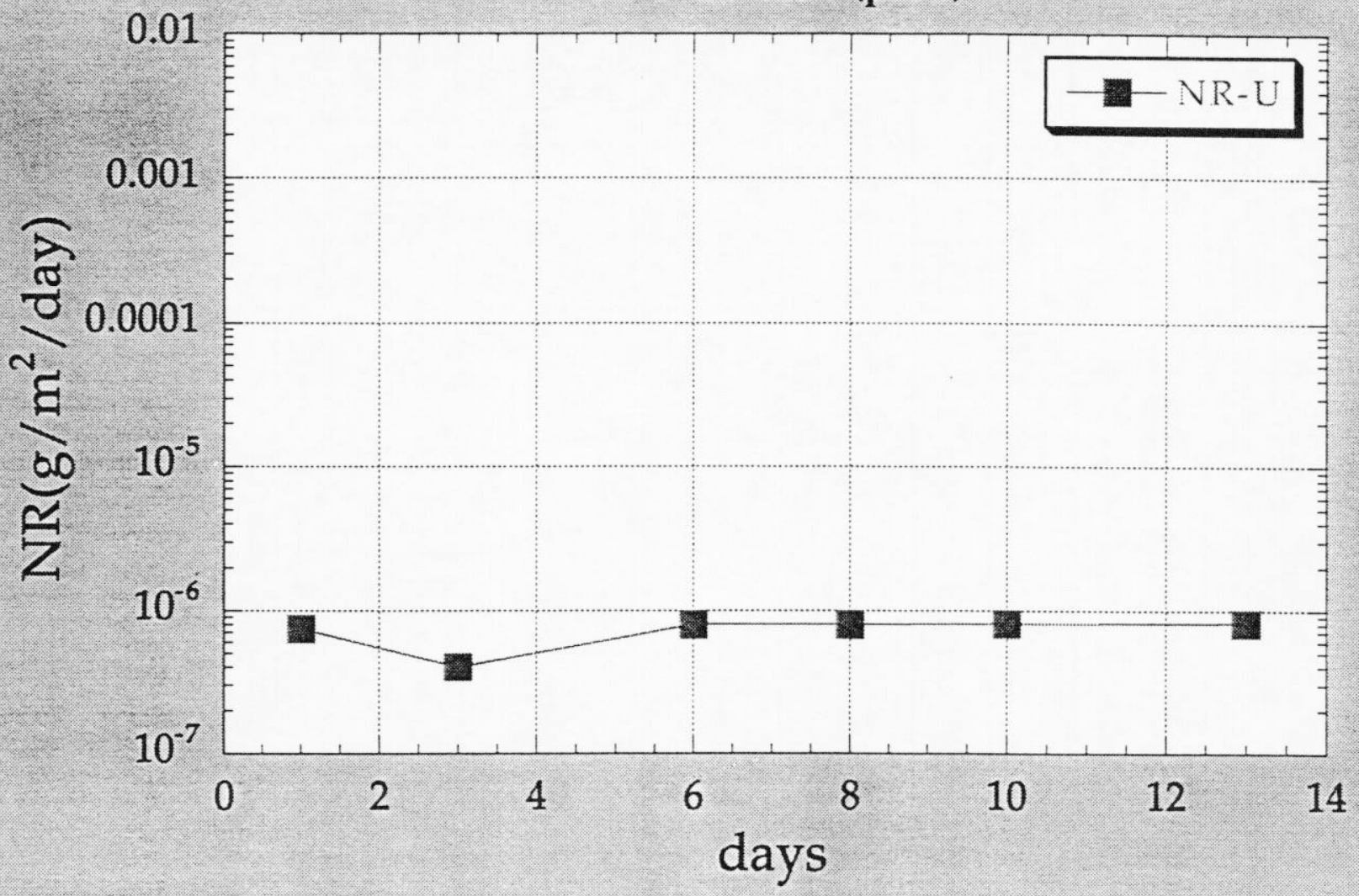



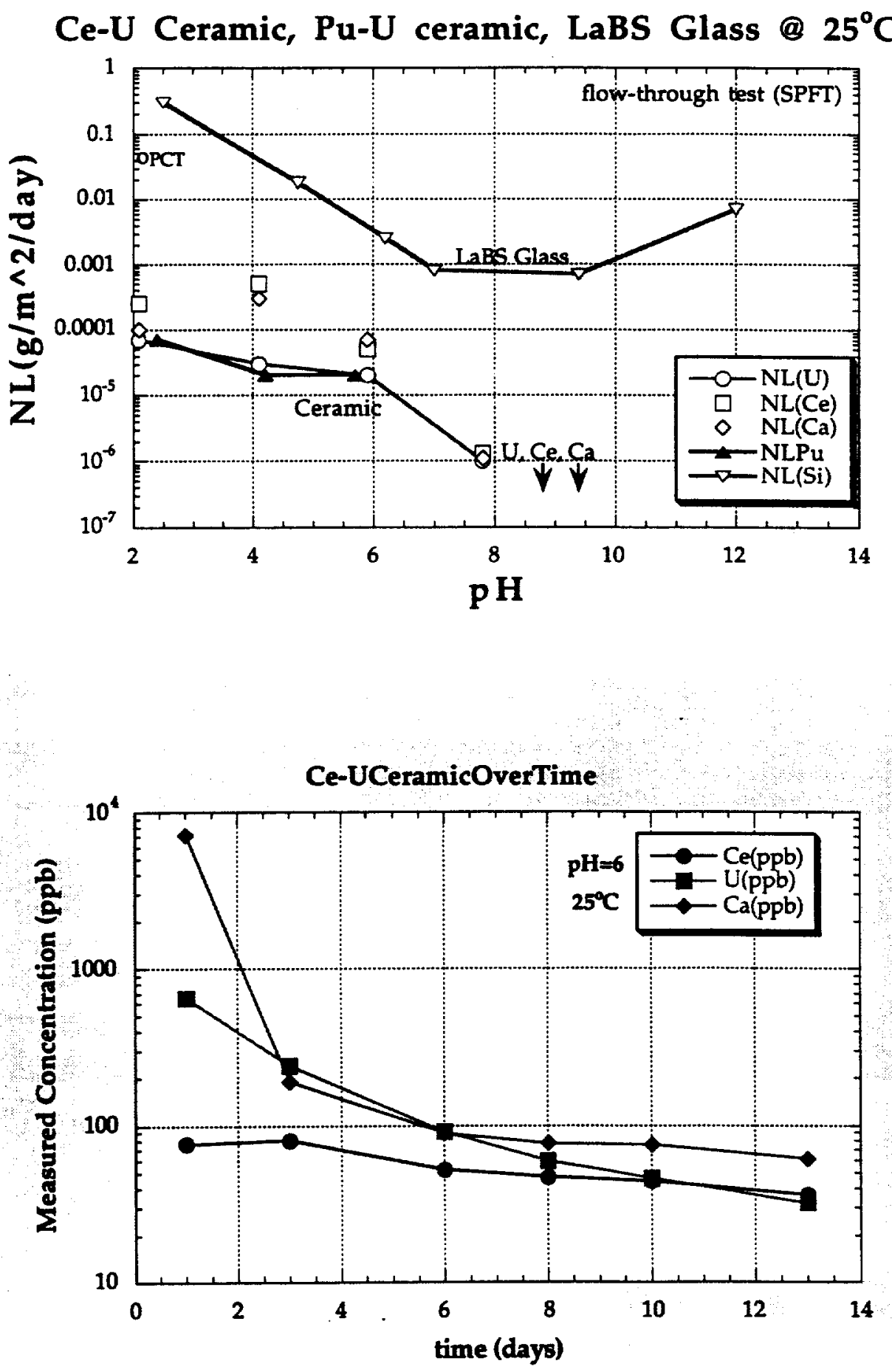


\begin{tabular}{|c|c|c|c|c|c|c|}
\hline \multicolumn{5}{|c|}{$\begin{array}{l}\text { SA/V"t calculations for MCC-1,PCT, and SPFT tests (for } \\
\text { SPFT } 30 \mathrm{ml} / \text { day, } 4 \mathrm{ml} \text { cell) }\end{array}$} & \multirow[b]{2}{*}{ SA/V $\left(m^{\wedge}-1\right)$} & \multirow[b]{2}{*}{$(S A / V)^{*}$} \\
\hline & $\mathrm{SA}\left(\mathrm{cm}^{\wedge} 2\right)$ & $\mathbf{V}(\mathrm{ml})$ & $t$ (days) & $\mathrm{SA} / \mathrm{V}\left(\mathrm{cm}^{\wedge}-1\right)$ & & \\
\hline SPFT & 1000 & 4 & 0.13 & 250 & 25000 & 3250 \\
\hline MCC-1 & 4 & 40 & 3 & 0.1 & 10 & 30 \\
\hline PCT-A & 400 & 10 & 7 & 40 & 4000 & 28000 \\
\hline
\end{tabular}

Depth of Attack in Nanometers

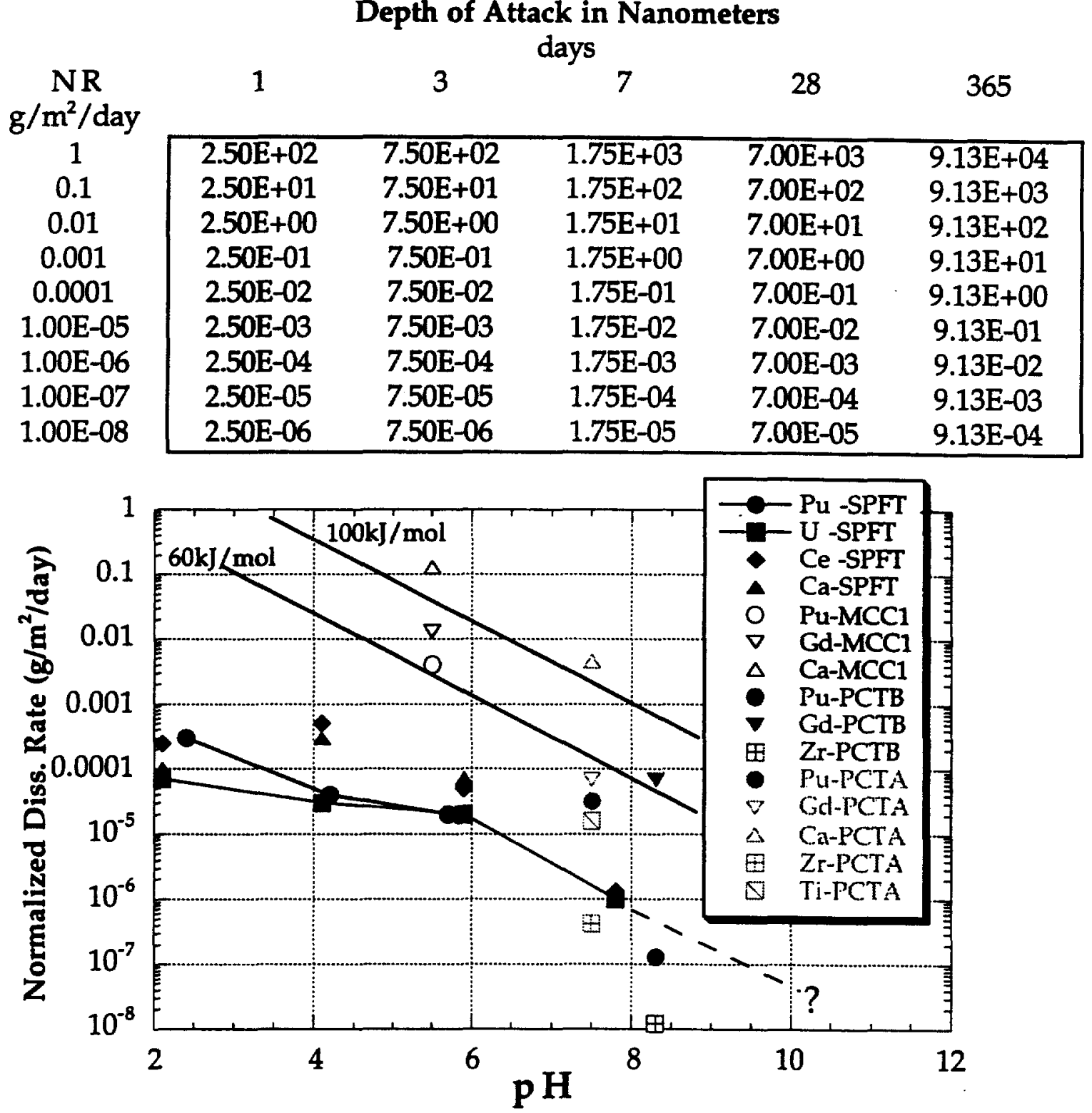




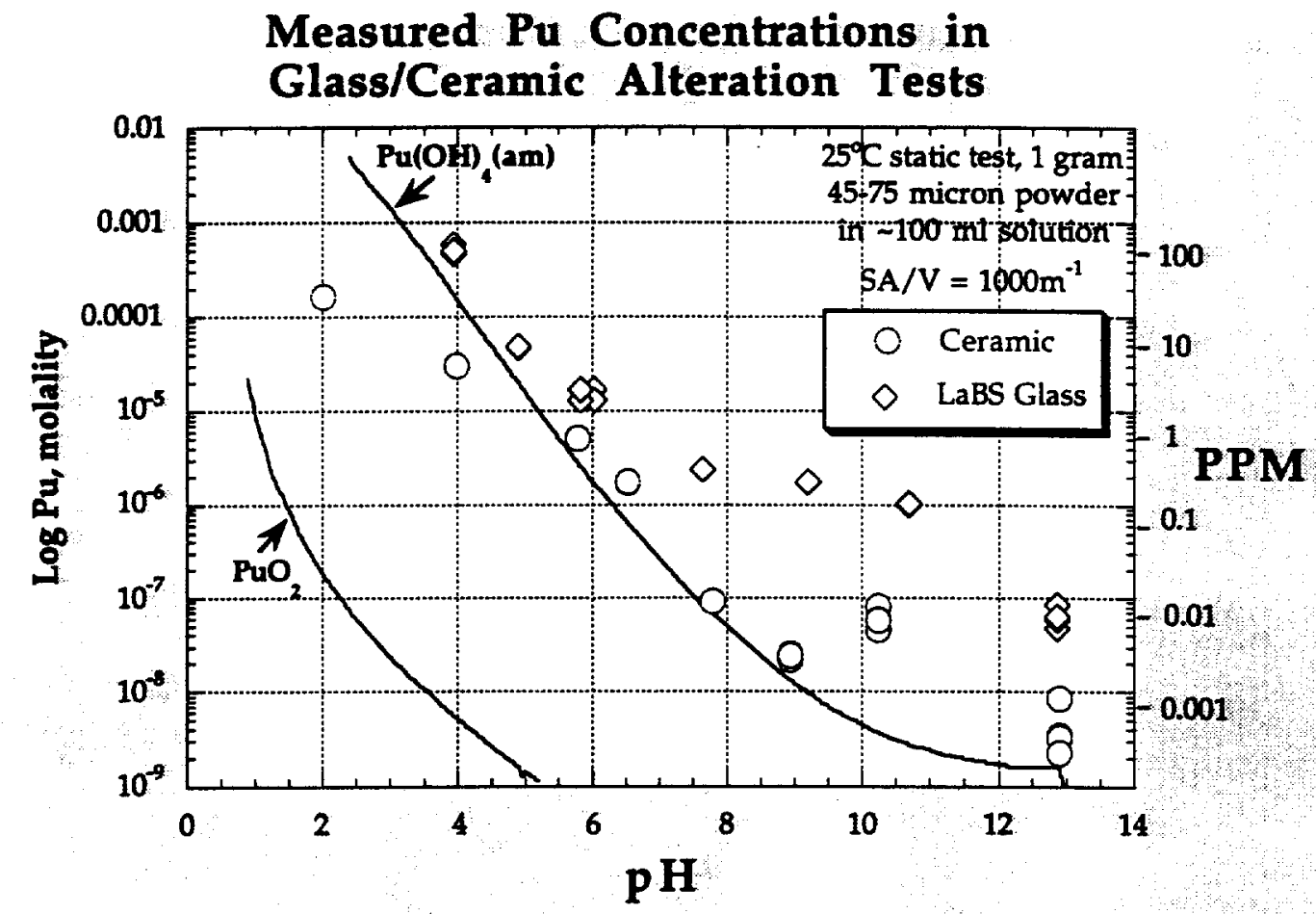

Summary:

1. Pu release is 1-1.5 log unit faster from LaBS glass than from zirconolite ceramic.

2. $\mathrm{Pu}$ concentrations remain above saturation levels of Pu-oxides over periods of at least months. 


\section{Problems With Interpretation of Ceramic Durability Test Results}

Much of the test data for elements released from the waste forms reflects solubilities of secondary phases and therefore cannot be used to determine release rates. It only provides a minimum reaction rate.

Many of the elemental concentrations are below detection limits and therefore the data provide only upper bounds on release rates. It is critical in performing durability tests to characterize background concentrations and report background corrected data.

Because the ceramic contains no soluble elements, such as boron in LaBS glass, which provide a measure of overall alteration rate, the ceramics elemental release data for many of the tests cannot be related to the overall reaction rate of the ceramic. 


\section{Conclusions}

Flow-through dissolution test data consistent with protective $\mathrm{TiO}_{2}$-layer ( $\mathrm{Ti}$ and $\mathrm{Hf}$ are slowest released elements).

Amorphization of ceramic (metamict) over time will likely cause reaction rates to increase by a factor of around 30 (based on data for other titanate-based ceramics).

$\mathrm{Pu}$ is able to stay in solution in experiments at concentrations much higher than even solubility limits of the amorphous $\mathrm{Pu}(\mathrm{OH})_{4}$ hydroxide solid (also true for REE).

Ceramic shows factor of 100-1000 times greater durability than LaBS glass under identical SPFT test conditions.

Rate of diffusion controlled dissolution process (ceramic) will not increase with temperature as fast as surface controlled process (glass). 


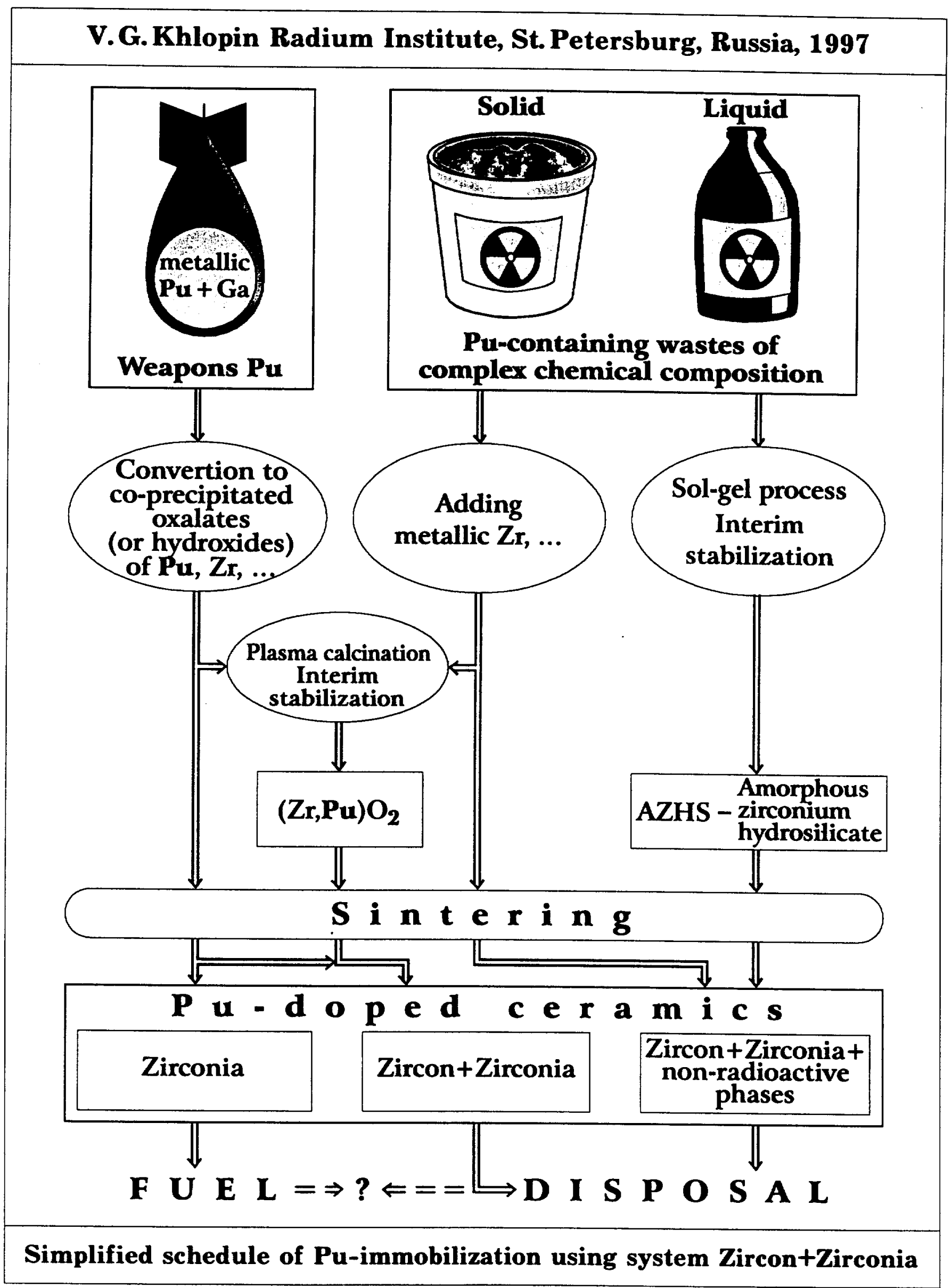




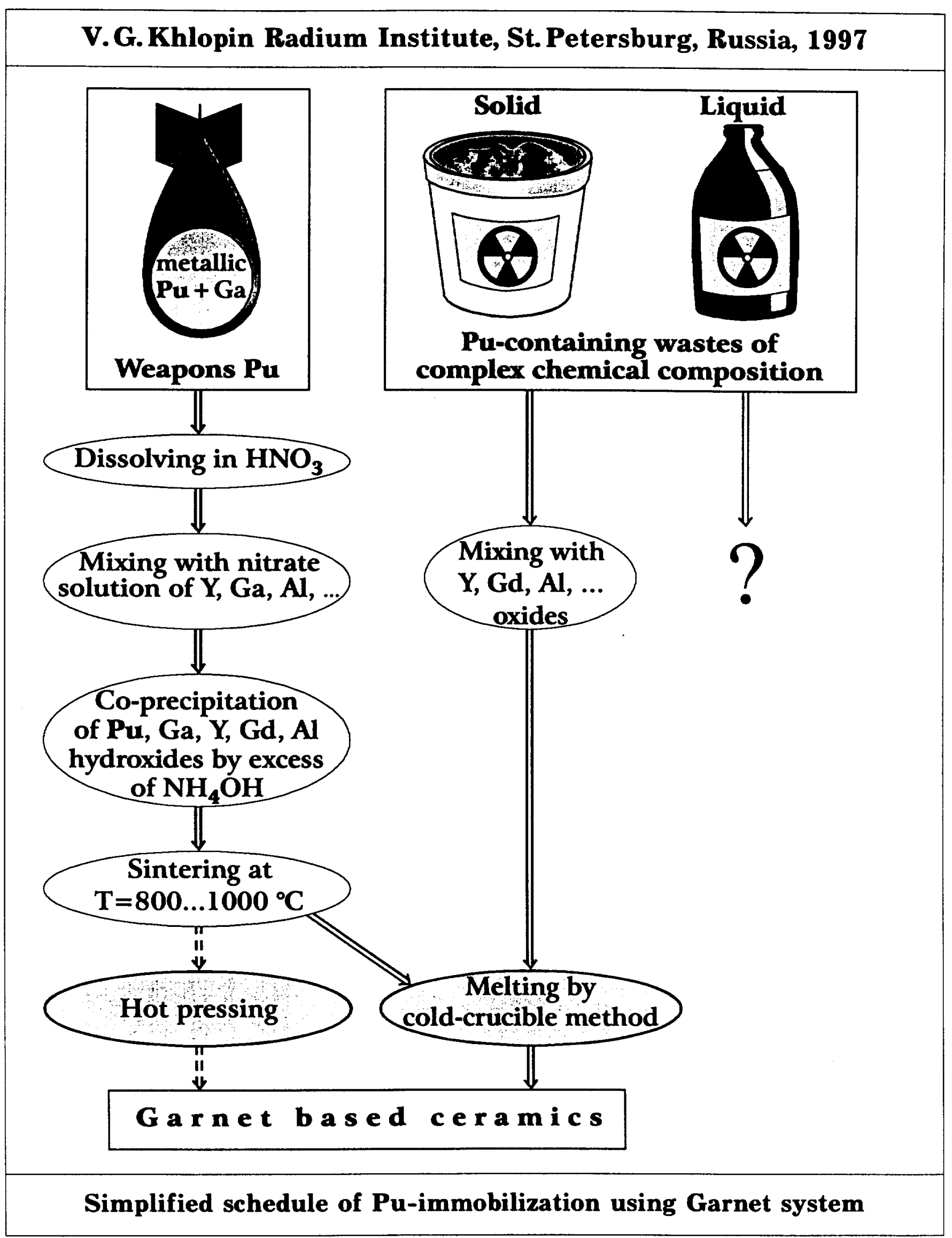




\section{G. Khlopin Radium Institute, St. Petersburg, Russia - University of New Mexico, Albuquerque, NM, USA, 1997}

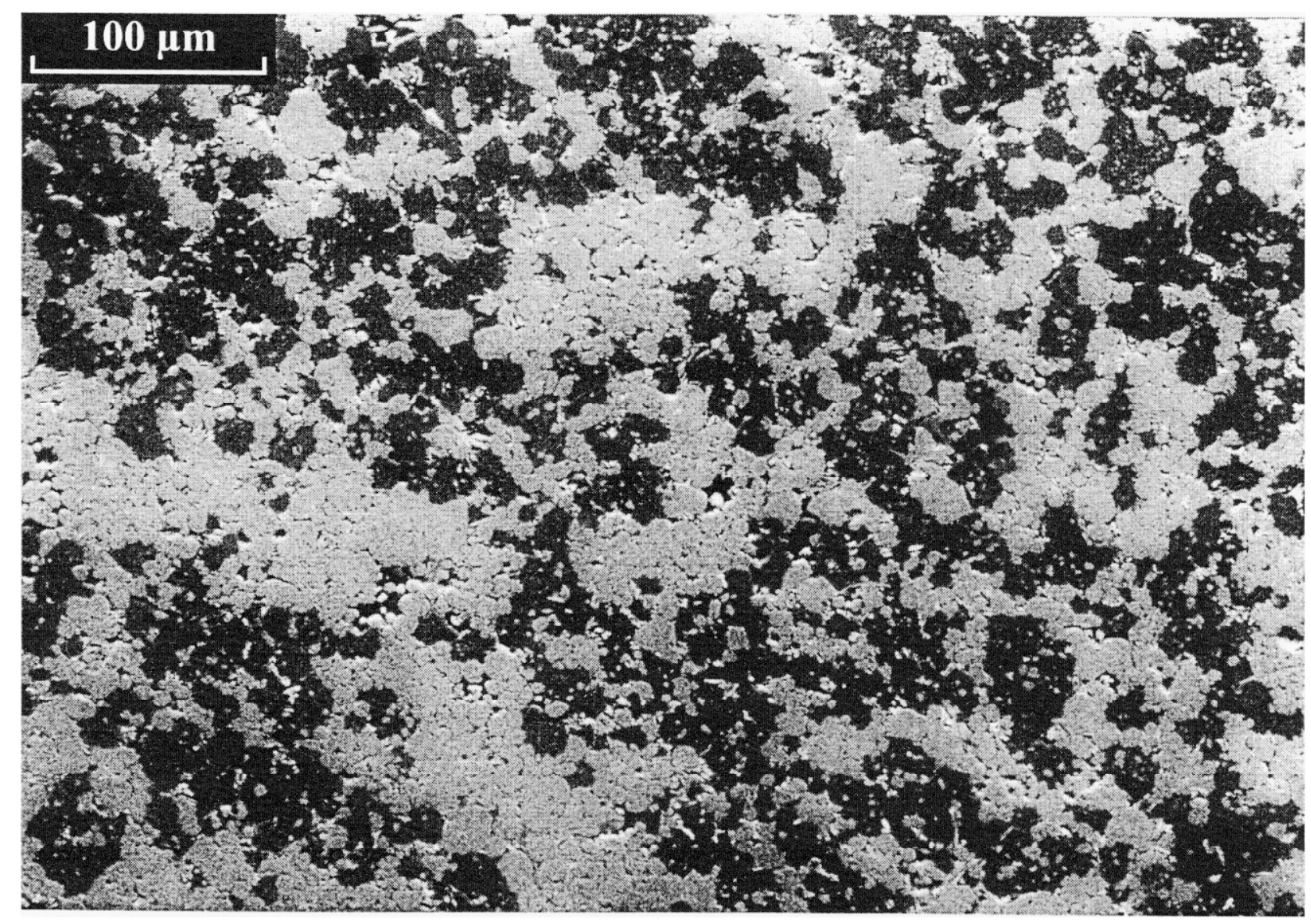

Crystalline ceramics based on two host phases: Zircon $(\mathrm{Zr}, \mathrm{Ce}) \mathrm{SiO}_{4}$ - dark, and Zirconia $(\mathrm{Zr}, \mathrm{Ce}) \mathrm{O}_{2}$ - bright. Synthesis by sintering in the air at $1600^{\circ} \mathrm{C}, 1$ hour. Precursor: plasma calcined $(\mathrm{Zr}, \mathrm{Ce})$ oxalates, amorphous $\mathrm{SiO}_{2}$. 

Submitted to "Waste Management'98"

Tucson, AZ, USA, March 3, 1998

\title{
Garnet Solid Solution of $\mathrm{Y}_{3} \mathrm{Al}_{5} \mathrm{O}_{12}-\mathrm{Gd}_{3} \mathrm{Ga}_{5} \mathrm{O}_{12}-\mathrm{Y}_{3} \mathrm{Ga}_{5} \mathrm{O}_{12}$ (YAG-GGG-YGG) as a Prospective Crystalline Host-Phase for Pu Immobilization in the Presence of Ga
}

\author{
B. E. Burakov, E. E. Strykanova
}

V. G. Khlopin Radium Institute

28, $2^{\text {nd }}$-Murinskiy Ave., St. Petersburg, 194021, Russia

Tel. $+7+812$ 346-1186, Fax: $+7+812$ 346-1129, E-mail: burakov@riand.spb.su

\section{AbSTRACT}

Weapons plutonium pits contain significant admixture of $\mathrm{Ga}$ (up to $3 \% \mathrm{wt}$ ) in the form of a metallic alloy with $\mathrm{Pu}$. The different chemical behavior of $\mathrm{Ga}$ in comparison with $\mathrm{Pu}$ can impact the process for treating weapons grade plutonium to produce a durable waste form. As was shown in previous work, yttrium-aluminum garnet (YAG) $\mathrm{Y}_{3} \mathrm{Al}_{5} \mathrm{O}_{12}$ is a very durable crystalline hostphase with a lattice of high capacity for incorporating actinides. Crystalline ceramics based on YAG have been proposed for actinide transmutation and as a component of Pu-containing nuclear fuel. This paper considers a solid solution of YAG with other garnets: $\mathrm{Gd}_{3} \mathrm{Ga}_{5} \mathrm{O}_{12}$ (GGG) and $\mathrm{Y}_{3} \mathrm{Ga}_{5} \mathrm{O}_{12}$ (YGG) as a prospective host-phase for immobilization of weapons grade $\mathrm{Pu}$ in the presence of $\mathrm{Ga}$. The advantages of this are:

1) GGG and YGG form unlimited solid solution with YAG that are also durable phases;

2) the possibility to achieve a direct conversion of plutonium pits to the stable ceramic and avoiding chemical separation of $\mathrm{Ga}$;

3) the possibility to incorporate in the lattice of this host phase not only Ga but also $\mathrm{Gd}$ as an effective neutron absorbant and all rare-earth elements in different valence states and $\mathrm{Fe}, \mathrm{V}, \mathrm{Cr}, \mathrm{Zr}$;

4) the possibility to use the YAG-GGG-YGG system for stabilization of $\mathrm{Pu}$-containing wastes with complex chemical compositions.

The physico-chemical features of YAG-GGG-YGG solid solution are described. As a conclusion the optimal methods of YAG-GGG-YGG synthesis using existing technologies are discussed. 



\section{1st International Symposium on the Scientific Basis for Nuclear Waste Management}

\section{MRS'97}

September 28th to October 3rd, 1997 Davos Congress Center, Switzerland

\section{Abstracts}




\title{
SYNTHESIS OF ACTINIDE-DOPED ZIRCONIA BY PLASMA CALCINATION
}

\author{
B.E. Burakov*, K.B. Helean**, V.A. Korolev*, R.C. Ewing**, E.B. Anderson*, L.B. Shpunt*, \\ E.E. Strykanova* \\ * V.G. Khlopin Radium Institute, St. Petersburg, Russia \\ ** Dept. of Earth \& Planetary Sci., Univ. of New Mexico, Albuquerque, NM, 87131 USA
}

Zirconia containing actinides in solid solution, (Zr. An) $\mathrm{O}_{x}$ where $\mathrm{An}=\mathrm{U}, \mathrm{Pu}, \mathrm{Am}, \mathrm{Np}, \mathrm{Cm}$ is considered as a starting material for the synthesis of two durable crystalline hostphases for actinide immobilisation: zircon ( $\mathrm{Zr}, \mathrm{An}) \mathrm{SiO}_{4}$ and cubic zirconia $(\mathrm{Zr}, \mathrm{An}) \mathrm{O}_{2}$. The use of this starting material is necessary in order to provide for total actinide incorporation into the structures of the final phases, zircon and cubic zirconia, while avoiding the presence of unincorporated actinides. Difficulties arise when the chemically inert pure oxides, $\mathrm{ZrO}_{2}$ and $\mathrm{AnO}_{x}$ are used as precursor materials. Melting techniques, which are commonly used to provide solid solution of inert oxides are not acceptable for ceramic preparation, particularly the synthesis of ceramic Pu-fuels. This paper presents a new approach utilising plasma calcination. Solids containing both zirconium and actinides are calcined in a plasma. This allows the use of intermediate, stabilised actinide forms, for example, co-precipitated actinide-zirconium oxalates which have a low solubility level or a solid sol-gel precursor, such as $(\mathrm{Zr}, \mathrm{An}) \mathrm{SiO}_{\mathrm{x}}$.

Calcination was completed using an induction plasma in an argon gas medium. Two types of material were used; co-precipitated oxalates of $\mathrm{Zr}$ with $10 \mathrm{wt} . \% \mathrm{Ce}$ and a solidified sol-gel $(\mathrm{Zr}, \mathrm{Ce}) \mathrm{SiO}_{\mathrm{x}}$ with $10 \mathrm{wt}$.\% Ce. Weakly milled material with a particle size of $0.34 \mathrm{~mm}$ was dropped through the plasma at a speed of 40-60 grams per hour. The final product was examined by high resolution transmission electron microscopy (HRTEM). The calcined oxalate material consisted of aggregates of globular particles (tens to hundreds of $\mathrm{nm}$ ) of monoclinic and tetragonal $(\mathrm{Zr}, \mathrm{Ce}) \mathrm{O}_{2}$. The calcined sol-gel consisted of globular particles (50 to $100 \mathrm{~nm}$ ) of cubic (or psuedo-cubic) (Zr, Ce)O2 in an amorphous silica matrix. This paper discusses the application of plasma calcination to the immobilisation of excess weapons $\mathrm{Pu}$ and other actinides. The plasma calcination of solid materials would be used for ceramic Pu-fuel fabrication, as well as for the final disposal in geological formations. 


\author{
B.E. Burakov*, K.B. Helean**, V.A. Korolev*, R.C. Ewing**, E.B. Anderson*, \\ L.B. Shpunt*, E.E. Strykanova*
}

*V.G. Khlopin Radium Institute, St. Petersburg, Russia

**Dept. of Earth \& Planetary Sci., Univ. of New Mexico, Albuquerque, NM, 87131 USA

Zirconia containing actinides in solid solution, $(\mathrm{Zr}, \mathrm{An}) \mathrm{O}_{\mathrm{x}}$, where $\mathrm{An}=\mathrm{U}, \mathrm{Pu}, \mathrm{Am}, \mathrm{Np}$, $\mathrm{Cm}$ is considered as a starting material for the synthesis of two durable crystalline host-phases for actinide immobilization: zircon $(\mathrm{Zr}, \mathrm{An}) \mathrm{SiO}_{4}$ and cubic zirconia $(\mathrm{Zr}, \mathrm{An}) \mathrm{O}_{2}$. The use of this starting material is necessary in order to provide for total actinide incorporation into the structures of the final phases, zircon and cubic zirconia, while avoiding the presence of unincorporated actinides. Difficulties arise when the chemically inert pure oxides, $\mathrm{ZrO}_{2}$ and $\mathrm{AnO}_{x}$ are used as precursor materials. Melting techniques, which are commonly used to provide solid solution of inert oxides are not acceptable for ceramic preparation, particularly the synthesis of ceramic Pufuels. This paper presents a new approach utilizing plasma calcination. Solids containing both zirconium and actinides are calcined in a plasma. This allows the use of intermediate, stabilized actinide forms, for example, co-precipitated actinide-zirconium oxalates which have a low solubility level or a solid sol-gel precursor, such as $(\mathrm{Zr}, \mathrm{An}) \mathrm{SiO}_{\mathbf{x}}$.

Calcination was completed using an induction plasma in an argon gas medium. Two types of material were used: co-precipitated oxalates of $\mathrm{Zr}$ with $10 \mathrm{wt} . \% \mathrm{Ce}$ and a solidified sol-gel $(\mathrm{Zr}, \mathrm{Ce}) \mathrm{SiO}_{\mathrm{x}}$ with $10 \mathrm{wt} . \% \mathrm{Ce}$. Weakly milled material with a particle size of $0.34 \mathrm{~mm}$ was dropped through the plasma at a speed of $40-60$ grams per hour. The final product was examined by high resolution transmission electron microscopy (HRTEM). The calcined oxalate material consisted of aggregates of globular particles (tens to hundreds of $\mathrm{nm}$ ) of monoclinic and tetragonal $(\mathrm{Zr}, \mathrm{Ce}) \mathrm{O}_{2}$. The calcined sol-gel consisted of globular particles ( 50 to $100 \mathrm{~nm}$ ) of cubic (or psuedo-cubic) $(\mathrm{Zr}, \mathrm{Ce}) \mathrm{O}_{2}$ in an amorphous silica matrix. This paper discusses the application of plasma calcination to the immobilization of excess weapons $\mathrm{Pu}$ and other actinides. The plasma calcination of solid materials would be used for ceramic Pu-fuel fabrication, as well as for the final disposal in geological formations. 



\title{
THE BEHAVIOR OF NUCLEAR FUEL IN FIRST DAYS OF THE CHERNOBYL ACCIDENT
}

\author{
B.E. BURAKOV*, E.B. ANDERSON*, S.I. SHABALEV*, E.E. STRYKANOVA*, S.V. USHAKOV*, \\ M. TROTABAS**, J-Y. BLANC**, P. WINTER**, J. DUCO*** \\ *V.G. Khlopin Radium Institute, 28, $2^{\text {nd }}$ Murinsky ave., 194021, St.Petersburg, Russia, \\ **Center D'Etudes de Saclay, 91191 Gif-Sur, Yvette CEDEX, France \\ ***IPSN, 60-68 ave. du General Leclerc, BP6-92265 Fontenay-Aux-Roses CEDEX, France
}

\section{ABSTRACT}

Various types of Chernobyl fuel containing masses named black "lava", brown "lava", porous "ceramic" and "hot" particles that formed during first days of the accident at the Chernobyl Nuclear Power Plant 4th Unit were studied by methods of optical and electron microscopy, microprobe and $x$-ray diffraction. Data about their chemical, phase and radionuclide composition are summarized. The products of interaction between fuel, zircaloy and concrete, produced under experiments in laboratory were examined for comparison with samples of Chernobyl "lava" and "hot" particles. The behavior of nuclear fuel in first days of the Chernobyl accident was a threestage process. The first stage occurred before the moment of the Chernobyl explosion and was exceptionally short-lasting, perhaps, less than a few seconds. It was characterized by reaching a high temperature, $\geq 2600^{\circ} \mathrm{C}$, in the epicenter of accident and formation of a $\mathrm{Zr}-\mathrm{U}-\mathrm{O}$ melt in a local part of the core, which is estimated to be not more than $30 \%$ of whole core volume. The second stage lasted for about 6 days since the explosion, during which there was interaction between uranium products of the destroyed reactor: $\mathrm{UOx}, \mathrm{UOx}$ with $\mathrm{Zr}, \mathrm{Zr}-\mathrm{U}-\mathrm{O}$, with the environment and silicate structural materials of the 4th Unit. The third stage, after 6 days involved the process of final formation of the radioactive silicate melt or Chernobyl "lava" at one of the sections of the destroyed 4th Unit. During this stage the melt's lamination occurred, followed by a break-through of the "lava" reservoir on the 11 th day of the accident and penetration of the "lava" into space under the reactor.

\section{INTRODUCTION}

The accident at the Chernobyl Nuclear Power Plant (ChNPP) 4th Unit on 26 April 1986 was accompanied by the destruction of the reactor core, a fire, and the release to the environment of a tremendous amount of solid and gaseous radioactive products. The activity of release is estimated to be for $\mathrm{Kr}-85: 3.3 \cdot 10^{16} \mathrm{~Bq}, \mathrm{Xe}-133: 1.7 \cdot 10^{18} \mathrm{~Bq}$ and all other nuclides $1 \cdot 10^{18}-2 \cdot 10^{18}$ $\mathrm{Bq}$ [1-3]. As a result of the accident, a part of nuclear fuel of the 4th Unit was dispersed by the explosion, and as dust or "hot" particles settled on the surface of soil and house roofs over a distance of hundreds kilometers from the ChNPP, as well as contaminating premises of the forth Unit [414]. The quantity of the dispersed fuel released to the environment outside the boundaries of the ChNPP industrial site is estimated as $3.5 \%$ of the whole fuel volume (190 metric tons of $\mathrm{UO}_{2}$ ) of the 4th Unit [1,3,7]; however, this figure may be an underestimate. The amount of fuel dust in spaces of the "Sarcophagus" or the object "Shelter", built over the ruins of the 4th Unit, perhaps, is considerably greater [7], but this is difficult to estimate correctly.

Another part of the 4th Unit's nuclear fuel, remained after explosion inside the ruins of the reactor, reacted with silicate construction materials: sand, concrete, serpentenite and formed "lava-like" fuel-containing masses or Chemobyl "lava". The "lava" spilled and hardened under 
the reactor [7,15-17]. A black and brown "lava" may be distinguished, as well as "porous ceramics" a product of brown "lava" coming into contact with water. The volume of visually studied "lava" exceed $190 \mathrm{~m}^{3}$, the quantity of fuel bound with them, in the dissolving form and solid inclusions, accounted, presumably, from 11 to $33 \%$ of the whole fuel volume of 4 th Unit [17].

Considerable amount of nuclear fuel, which is hard to estimate, retained its main physicochemical characteristics during the course of the accident. This part of the fuel includes fuel rods and their fragments scattered by the explosion over the 4th Unit ruins, as well as that which remained in broken off technological channels of the reactor's upper slab $[7,16]$. Thus, the Chernobyl accident caused a structural and chemical transformation of a considerable part, not less than $30 \%$, of the 4th Unit's nuclear fuel. The behavior of this fuel in the course of the accident was determined not so much by its mechanical destruction as by the formation of various uranium containing compounds [11,14,19-22]. This affected the dynamics of radionuclide release and features of the radioactive contamination of the surrounding territories.

In this paper, we consider the Chernobyl accident as a three-stage process of destruction and transformation of uranium fuel. Each stage was distinguished by comparing the results of our study of the different uranium-containing products of Chernobyl "lava" and "hot" particles with the dynamics of radionuclide release in the period from 26 April until 6 May 1986 [3,7]. The paper is based on materials investigated at the V. G. Khlopin Radium Institute, carried out at Chernobyl and in St. Petersburg in the years 1990-1994. Also used are results of studies of a series of Chernobyl samples by the Saclay Nuclear Center (France) performed in 1992-93 within the scope of collaboration between the Institut de Protection et de Surete Nucleaire, Departement de Mecanique et de Technologie (France) and the Radium Institute (Russia).

\section{SAMPLES}

Without doubt, before the moment of explosion of ChNPP 4th Unit, a considerable part of nuclear fuel had already experienced overheating. For a limited part of the fuel of the damaged reactor calculations suggest temperatures of $3000^{\circ} \mathrm{C}$ [2] and in some cases above $6000^{\circ} \mathrm{C}$ [23].

Thus, the "hot" particles ejected during the explosion of the 4th Unit, and not undergoing a subsequent interaction with structural materials, must contain information about the initial stage of the accident [14]. These small solid particles from a few to tens of microns in size can record the temperature and other conditions that occurred inside reactor before the moment of explosion, and reflect these conditions in their chemical and radionuclide compositions of phases. After the destruction of the Chernobyl reactor an active transmission of radionuclides bound to the "hot" particles continued for about 10-11 days [3,7]. However, the chemistry and phases formed in these particles was influenced by later processes, such as burning of graphite $[8,10]$.

To identify "hot" particles, whose matrices reflect the temperature and chemical changes of the fuel before the moment of explosion, samples of soil were obtained along the axis of the Western Plume over the distance of $12 \mathrm{~km}$ from ChNPP. This territory is characterized by the maximum levels of radioactive contamination (more than $40 \mathrm{Ci} / \mathrm{km}^{2}$ for Cs-137) caused by the earliest fallout of "hot" particles after the destruction of ChNPP 4th Unit. Biological investigations of radiation damage to the pine-trees revealed unique peculiarities of the process of formation of the Western Plume. It was determined that the radioactive cloud in the immediate vicinity of the reactor was suprisingly moving as a narrow band $1-1.5 \mathrm{~km}$ in width piercing the forest to the west. Along the first 5 kilometers cloud moved into relatively thick forest and a further 5-6 kilometers under this cover without significant spreading . [24]. Along the whole 
length of that portion at distances up to $12 \mathrm{~km}$ from the ChNPP, very large fuel particles were found up to hundreds of microns in size. The transport of a large amount of comparatively heavy particles was probably the result of the explosion, rather than subsequent events of the accident.

After the destruction of the reactor core a part of nuclear fuel interacted with silicates used as structural materials of the reactor, thus forming a silicate "lava" [7,15-17]. Visual studies of hardened Chernobyl "lava", hardened in premises of the "Sarcophagus" or "Shelter", revealed three main flows with a common source [17]. In our investigations the sample collection was determined by: accessibility of samples under conditions of extremely high radiation fields, reaching more than $1000 \mathrm{R} /$ hour in some places; visual differences of the "lava" by color and porosity; vertical and horizontal location of sampling areas. A simplified scheme of disposition of the Chernobyl "lava" by height levels with an indication of sample location is shown in Fig. 1.

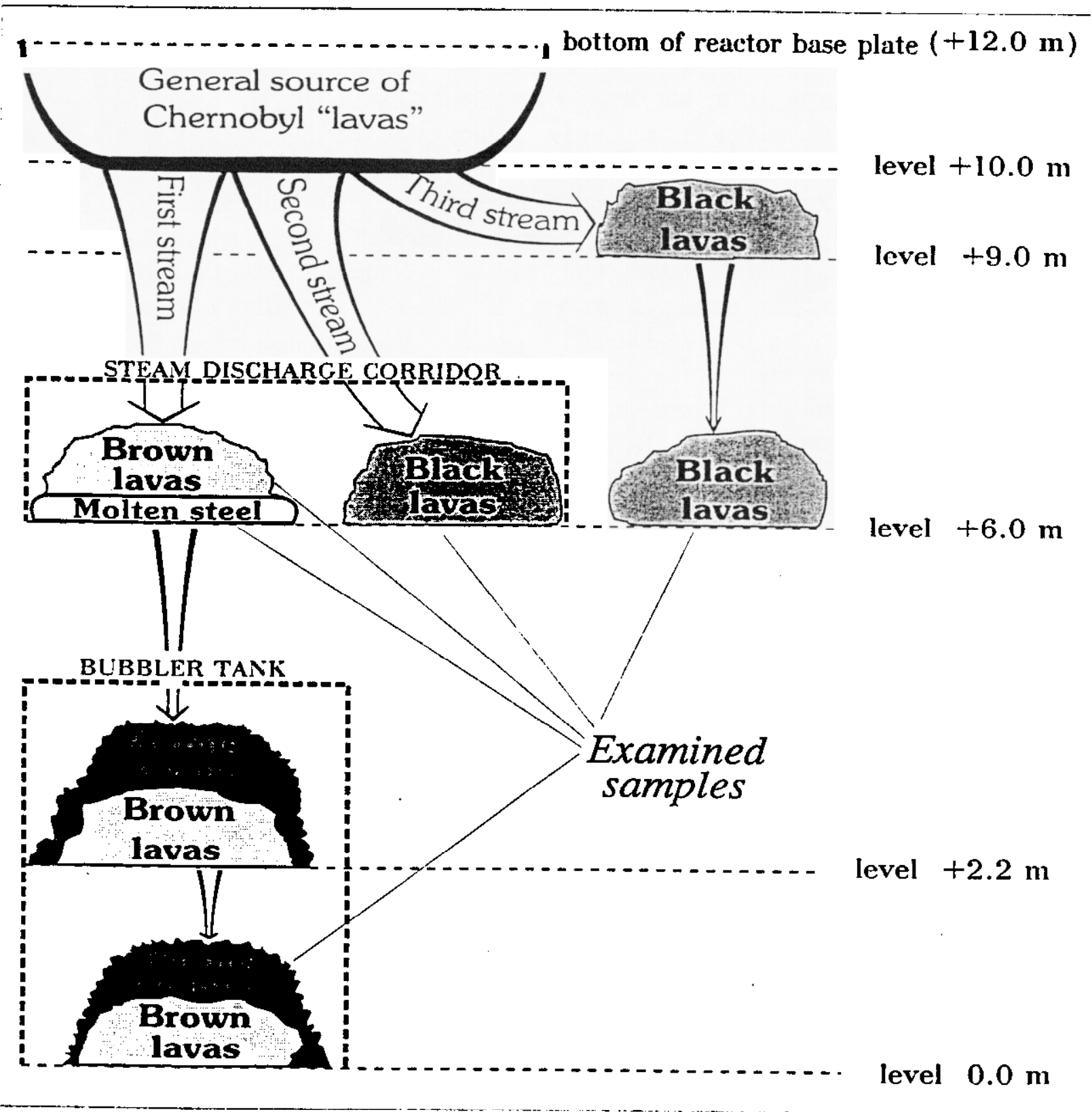

Fig. 1. Height distribution of various types of Chernobyl "lavas" by height levels with indication of sampling places 
In general, the samples we were able to collect are not representative or numerous enough. Most representative samples are of the brown "lava" from the steam discharge corridor where the "lava" layer thickness did not exceed $15 \mathrm{~cm}$. It was considerably more difficult to obtain samples of black "lava" from thicker formations, therefore samples were studied from the subsurface sections of "lava" streams. For a more representative and detailed study of mineral inclusions found in the matrix of the "lava", large pieces of fuel-containing masses, tens of cubic centimeters in volume were dissolved in cold hydrofluoric acid. The insoluble residue, obtained as a result of this procedure, consisted of grains of various crystalline and amorphous phases. However, the separation of the inclusions was not complete. A certain portion of them, for example, small particles of uranium oxides, dissolved simultaneously with the glass-like matrix of the "lava".

\section{THE FIRST STAGE: NUCLEAR FUEL INTERACTION WITH THE ZIRCALOY CLADDING PRIOR TO THE CHERNOBYL EXPLOSION}

The process of active interaction of uranium dioxide, $\mathrm{UO}_{2}$, and zirconium metal at high temperatures was studied in detail. The solidification of the $\mathrm{Zr}-\mathrm{U}-\mathrm{O}$ melt, occurring at a temperature of $1900^{\circ} \mathrm{C}$, led to the formation of an eutectic two-phase composition $\mathrm{UO}_{2} / \alpha-\mathrm{Zr}(\mathrm{O})$ [25]. The behavior of the $\mathrm{Zr}-\mathrm{U}-\mathrm{O}$ melt at a temperature $2500-2600^{\circ} \mathrm{C}$ to a large extent depends on the ratio of the $\mathrm{UO}_{2}$ and $\mathrm{Zr}$ starting components, as well as on the rate of heating.

Experiments under laboratory conditions at temperatures of $1900,2600^{\circ} \mathrm{C}$ in vacuum and in argon showed that the interaction between $\mathrm{UO}_{2}$ and zirconium metal $\alpha-\mathrm{Zr}$ or $\alpha-\operatorname{Zr}(\mathrm{O})$ does not proceed in presence of even a small quantity of air in the reaction chamber. Formation of an inert film of $\mathrm{ZrO}_{2}$ completely blocks the formation of the $\mathrm{Zr}-\mathrm{U}-\mathrm{O}$ melt. A rapid solidification of the $\mathrm{Zr}-\mathrm{U}-\mathrm{O}$ melt heated up in vacuum to $2600^{\circ} \mathrm{C}$ leads to formation of a polyphase ceramic. The matrix of the ceramic consists of:

1. $\mathrm{UO}_{\mathrm{X}}$ that may be considered as unreacted relicts of the initial $\mathrm{UO}_{2}$.

2. $\mathrm{UO}_{\mathrm{X}}$ with $\mathrm{Zr}$, in which the content of zirconium is not constant, but does not exceed $10 \%$ by mass.

3. $\mathrm{Zr}-\mathrm{U}-\mathrm{O}$, in which both uranium and zirconium are the main components. In experiments, the zirconium concentration in the $\mathrm{Zr}-\mathrm{U}-\mathrm{O}$ phase is higher than that of uranium. This may be caused by the fact that the diffusion of uranium and oxygen into zirconium metal under the non-equilibrium conditions of rapid heating up to $2600^{\circ} \mathrm{C}$ is faster than the simultaneous process of zirconium diffusion into uranium oxide.

4. Zirconium metal, presumably, $\alpha-\operatorname{Zr}(0)$ with an admixture of uranium. In the presence of excess $\mathrm{UO}_{2}$ in starting composition, the presence or absence of the $\alpha-\operatorname{Zr}(\mathrm{O})$ phase with $U$ in the matrix is determined only by the rate of heating the $\mathrm{Zr}-\mathrm{U}-\mathrm{O}$ melt up to $2600^{\circ} \mathrm{C}$ and then by the rate of cooling.

An investigation of "hot" particles from the Western Plume allowed us to establish that a considerable proportion of the "hot" particles are a product of interaction of fuel $\mathrm{UO}_{\mathrm{X}}$ with the zircaloy cladding [11,14]. Some polyphase particles in fact were analogues to samples synthesized in the laboratory as a result of short-time heating of uranium oxide pellet in contact with zircaloy up to $2600{ }^{\circ} \mathrm{C}$ in vacuum. The same phases: UOx, UOx with $\mathrm{Zr}, \mathrm{Zr}-\mathrm{U}-\mathrm{O}, \mathrm{Zr}$ metal with uranium admixture were identified in their matrices.

Results included: $i$ ) identification of $\mathrm{Zr}-\mathrm{U}-\mathrm{O}$ and $\mathrm{UOx}$ with $\mathrm{Zr}$ phases in the matrices of "hot" particles; ii) experimental synthesis of the same phases in association with UOx and $\mathrm{Zr}$ metal with uranium admixture under the non-equlibrium conditions of rapid heating up to 
$2600^{\circ} \mathrm{C}$ and only in the non-air media, are the basis of our proposal that the initial stage of the Chernobyl accident was short-lasting, not more than a few seconds, was characterized by a temperature $\geq 2600^{\circ} \mathrm{C}$ at the epicenter prior to the explosion. In Fig. 2 is shown a physicochemical transformation of fuel before the moment of explosion on the level of a fuel rod fragment at the accident epicenter.

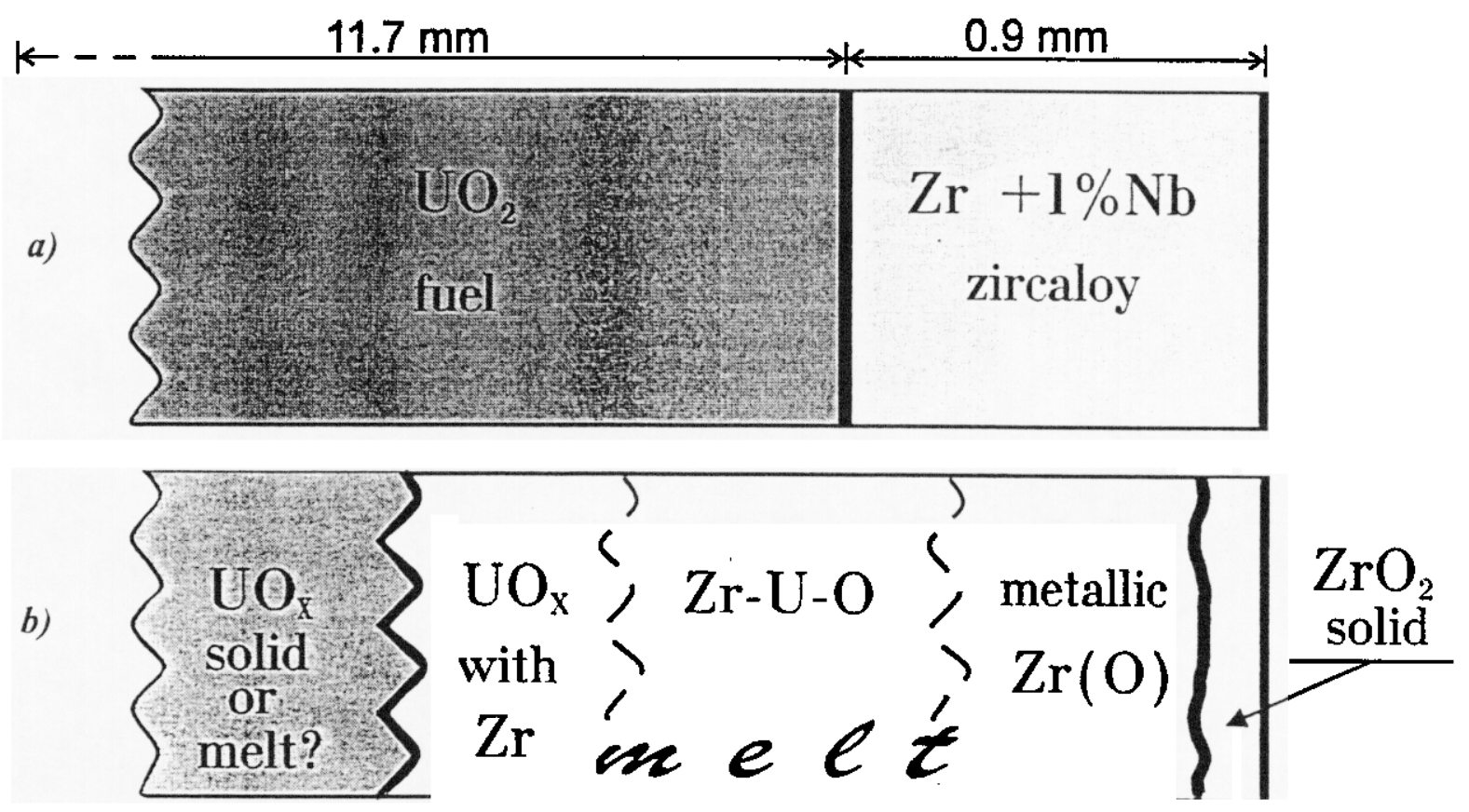

Fig. 2. A section view of a fuel rod fragment: a) initial structure;

b) before the explosion in the accident epicenter.

\section{THE SECOND STAGE: SIX DAYS AFTER THE EXPLOSION}

The explosion of the ChNPP 4th Unit completely destroyed the reactor core. The scorching fuel in the form of uranium oxide, as well as products of $\mathrm{UO}_{\mathrm{X}}$ with $\mathrm{Zr}$ and $\mathrm{Zr}-\mathrm{U}-\mathrm{O}$, escaped to and interacted with the environment. Overheating of the fuel materials caused a release of radionuclides that had evolved from the uranium matrix. Some of them, for example Ru-106, formed separate types of "hot" particles, having a matrix of pure Ru-106 metal [4,5]. In our investigations [11,14] we did not find these particles. However, there was noticed that "hot" particles, containing in their matrix metallic inclusions $\mathrm{Fe}-\mathrm{Cr}-\mathrm{Ni}$, were characterized by enrichment in Ru-106.

The release of different forms of radionuclides from fuel products at the 4th Unit ruins was going on during all 10 days after the explosion; however, in the first 6 days its intensity was continuously decreasing from $4.5 \cdot 10^{17}$ to $1 \cdot 10^{17} \mathrm{~Bq} / \mathrm{day}$ (error $\pm 50 \%$ ) [3,7]. Such a prolonged and active radionuclide release was caused mainly by residual heat-release of the destroyed fuel. Although one should not exclude an influence of a fire at the center for the very first days after the explosion $[7,8,10]$.

The melting of structural materials and steel began in places of fuel conglomeration. During this stage of the accident only the initial formation of the Chernobyl "lava" source occurred. In our opinion, this represented a non-uniform mixture of "cold" structural and "hot" fuel materials with the melt in the zone of direct contact. This stage ended on 2 May 1986, when separate 
sources of silicate melt began to consolidate in the common source of Chernobyl "lava" (Fig. 3). In general, the process of heat absorption due to destruction and melting of concrete, steel and sand, prevailed over the process of its release from separate local sources. Thus, there was a gradual decrease of radionuclide release in the period between 26 April untill 2 May 1986.

a)

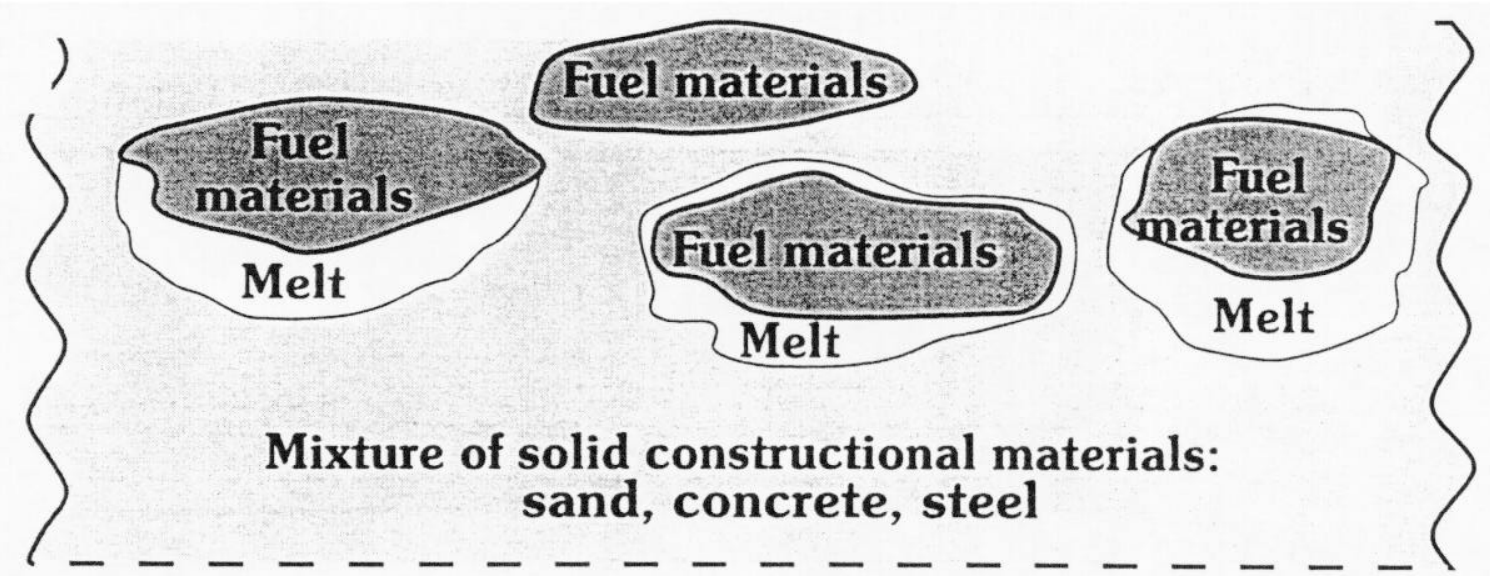

b)

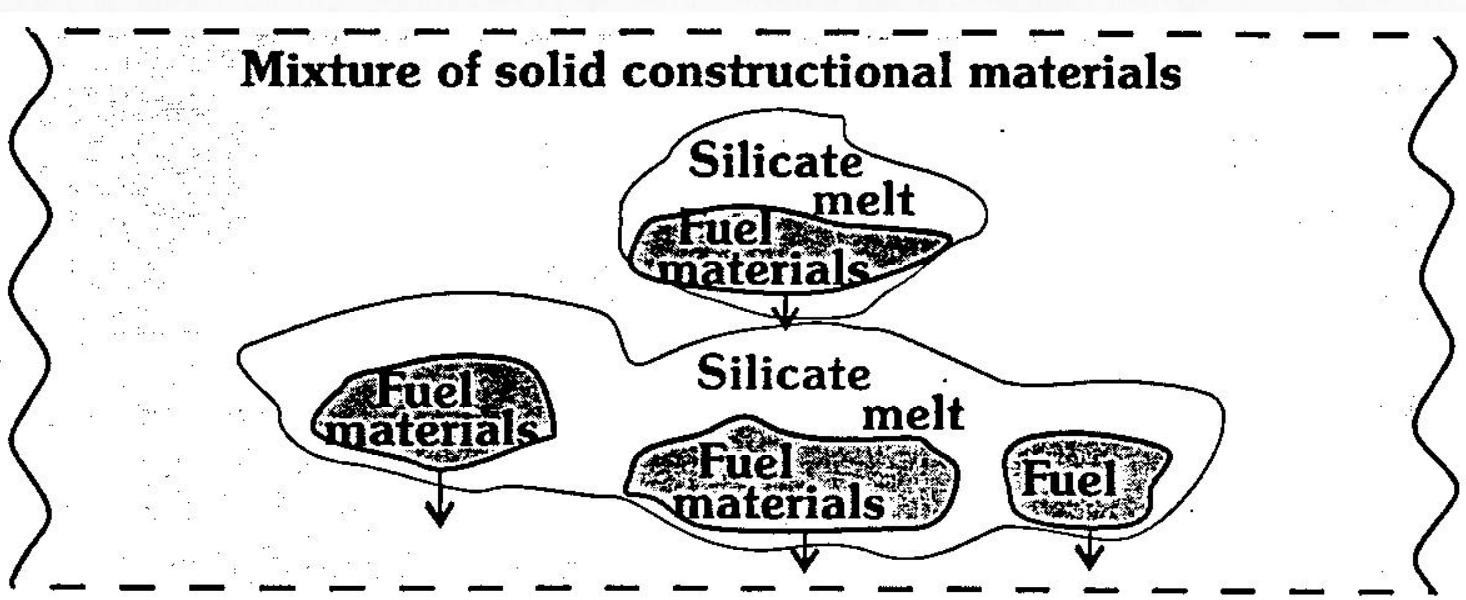

Fig. 3. General scheme of interaction between fuel in the form $\mathrm{UO}_{\mathrm{X}}, \mathrm{UO}_{\mathrm{X}}$ with $\mathrm{Zr}$ and $\mathrm{Zr}-\mathrm{U}-\mathrm{O}$, with structural materials in the period of the 2nd stage of the Accident: a) after the Chemobyl explosion on 26 April 1986, and b) on 2 May 1986.

THE THIRD STAGE: FINAL FORMATION OF THE CHERNOBYL "LAVA" SOURCE AND ITS BREAK-THROUGH

After 2 May, 1986, an increase of the radionuclide release was noted over the ChNPP 4th Unit's ruins. For several days the release continuously increased up to $3 \cdot 10^{17} \mathrm{~Bq} /$ day (error \pm $50 \%$ ) and on $6 \mathrm{May}, 1986$, it dropped abruptly to $0.2-0.6 \cdot 10^{16} \mathrm{~Bq} /$ day $[3,7]$.

During the period from 2 till 6 May 1986, we consider this as the time of the most vigorous physico-chemical transformation of the ChNPP nuclear fuel. We propose that on 2-3 May a united center of radioactive melt formed due to confluence of previously isolated sources, and by 5-6 May the temperature homogenation of the melt and its stratification into three layers was completed.

The main peculiarities of the formation of the Chernobyl "lava" center and the chemical transformation of fuel materials include:

- the uranium phases $\mathrm{UO}_{\mathrm{X}}, \mathrm{UO}_{\mathrm{X}}$ with $\mathrm{Zr}$ partly dissolved in the silicate melt; 
- a considerable part of the $\mathrm{Zr}-\mathrm{U}-\mathrm{O}$ phase came into chemical contact with the silicate melt, which caused the crystallisation of high-uranium zircon $(\mathrm{Zr}, \mathrm{U}) \mathrm{SiO}_{4}[20,21]$;

- a redistribution of the $\mathrm{Ru}-106$ occurred, that selectively concentrated $\mathrm{Ru}-106$ in drops of molten steel;

- under the action of gravity the molten metal and solid inclusions of the uranium phases began to gather in the lower part of the melt center.

In order to understand the peculiarities of the process of the "lava" formation, we used the results of studies of various solid inclusions in their matrices, for example, zircon $(\mathrm{Zr}, \mathrm{U}) \mathrm{SiO}_{4}$. It was shown, that inclusions of high-uranium zircon $(\mathrm{Zr}, \mathrm{U}) \mathrm{SiO}_{4}$ are present in all the studied types of Chernobyl "lava", including the "porous ceramics". It is evident that crystallization of zircon, $(\mathrm{Zr}, \mathrm{U}) \mathrm{SiO}_{4}$, had occurred before the moment of spreading-out of "lava" streams, because "porous ceramics" is a product of the practically instantaneous solidification of brown "lava" as it came into contact with water. It may be also stated, that the temperature of the silicate melt in the Chernobyl "lava" center did not exceed $1660-1700^{\circ} \mathrm{C}$ [21] - the limit of zircon's thermal stability [26,27]. An attempt was made to indirectly assess the time required for the crystallisation of the high-uranium zircon $(\mathrm{Zr}, \mathrm{U}) \mathrm{SiO}_{4}$ in the "lava", admitting a certain analogy to results for the synthesis of crystalline zircon by the method of crystallisation from a melt under laboratory conditions [29-31]. Calculations showed that the formation of high-uranium zircon $(\mathrm{Zr}, \mathrm{U}) \mathrm{SiO}_{4}$ with crystals reaching a size of several hundreds microns requires approximately three days.

Thus, by 6 May 1986 the site where the Chernobyl "lava" originated was, presumably, represented by a radioactive melt separated into three layers:

1. Lower layer: metallic $\mathrm{Fe}-\mathrm{Cr}-\mathrm{Ni}$ close to the composition of structural stainless steel. The given layer did not contain dissolved uranium admixtures or solid inclusions of uranium phases. The radioactivity was caused by radionuclide ${ }^{106} \mathrm{Ru}$ and, partly, ${ }^{60} \mathrm{Co}$ and ${ }^{125} \mathrm{Sb}$.

2. Middle layer: silicate with dissolved admixtures of $\mathrm{U}, \mathrm{Zr}, \mathrm{Al}, \mathrm{K}, \mathrm{Ca}$, as well as with numerous dispersed solid inclusions of $\mathrm{UO}_{\mathrm{X}}$, UOx with $\mathrm{Zr}$, the phase $\mathrm{Zr}-\mathrm{U}-\mathrm{O}$, crystals of high-uranium zircon $(\mathrm{Zr}, \mathrm{U}) \mathrm{SiO}_{4}$.

3. Upper layer: silicate, similar in composition to the middle layer, but with a lesser amount of uranium phase solid inclusions.

For several days up to 6 May, 1986, something prevented the spreading out of Chernobyl "lava". We assume that in the zone of direct contact of the melt with concrete a stable thermoinsulating crust have formed, thus preventing a melting-through of the concrete constructions.

A sharp decrease of the radionuclide release on 6 May 1986 was probably caused by the spreading-out and cooling of the Chernobyl "lava". The three independent flows of "lava" left the common underreactor space, level +10.0 meters (Fig. 1). The primary source of the melt, however, was much higher, because the "lava" melted through the south-eastern part of the reactor base slab (+12.0 meters ). A small "leak" deposit of "lava" 0.5 meters in diameter and 1.2 meters in height, resembling a stalagmite remained at the surface of the reactor base slab in its north-eastern part [17].

A comparative analysis of the results from study of materials in the "lava" and of visual observations directly in the ruined 4th Unit shows that the primary site of formation of Chernobyl "lava" was outside the reactor shaft. In the course of spreading-out the composition of the silicate melt varied. Admixtures of magnesium appeared in it when the "lava" melted through the serpentinite-filled reactor base slab. Probably, the melting of the base occurred quickly. This caused the different magnesium contents in the matrices of brown and black "lava" (Table 1). 
Table 1. The chemical composition of the matrices from EDS analysis. (wt.\%). The number of analyses: porous ceramic - 55 , brown ceramic - 75 , black ceramic -79 .

\begin{tabular}{l|c|c|c|c|c|c|c|c|c}
\hline Types of "lava" & $\mathbf{F e}$ & $\mathbf{N a}$ & $\mathbf{S i}$ & $\mathbf{A l}$ & $\mathbf{M g}$ & $\mathbf{K}$ & $\mathbf{C a}$ & $\mathbf{Z r}$ & $\mathbf{U}$ \\
\hline porous ceramic & 0.2 & 0.5 & 35.2 & 3.8 & 4.5 & 2.3 & 7.5 & 4.0 & 2.9 \\
\hline brown "lava" & 0.2 & 0.6 & 36.6 & 4.0 & 4.4 & 2.3 & 7.2 & 2.9 & 2.0 \\
\hline black "lava" & 0.3 to $6.7^{*}$ & 0.4 & 37.2 & 3.8 & 1.3 to $3.2^{*}$ & 2.7 & $\mathbf{8 . 2}$ & 3.7 & 3.2 \\
\hline
\end{tabular}

* - contents in black "lava" from vertical stream (13 analyses)

The general succession of events concluding this stage of the accident were:

- On 5-6 May 1986 a break-through of the Chernobyl "lava" center occurred. The melt entered the reactor shaft and melted through the reactor base slab in the south-eastern part. The melt's spreading was not uniform, but comparatively rapid. In general, this initial stratification remained.

- A molten metal melt and a part of the silicate melt saturated with uranium phases as solid inclusions was the first to reach the +10.0 meter level and form a vertical flow of brown "lava" (Fig. 1).

- The upper part of the silicate melt reached the +10.0 meter level in the last turn following metal melt and brown "lava" and formed horizontal and vertical flows of black "lava" (Fig.1).

\section{SOLIDIFICATION OF CHERNOBYL "LAVA"}

Different types of "lava" solidified at different rates. This affected both the chemical composition of the matrix and peculiarities of the morphology, structure and chemical composition of uranium phases (Tables 1,2). The black "lava" solidified slowly, therefore no inclusions of the phase $\mathrm{Zr}-\mathrm{U}-\mathrm{O}$ was found in their matrices. Crystals of high-uranium zircon $(\mathrm{Zr}, \mathrm{U}) \mathrm{SiO}_{4}$ in this type of "lava" sometimes contain inclusions of a few microns in size of monoclinic zirconium dioxide $\mathrm{ZrO}_{2}$ with a $\mathrm{U}$ admixture up to 6-7 $\mathrm{wt} \%$. These inclusions may be considered as a result of crystallization of relicts of the $\mathrm{Zr}-\mathrm{U}-\mathrm{O}$ phase in course of zircon formation: $\mathrm{Zr}-\mathrm{U}-\mathrm{O}+\mathrm{SiO}_{2} \rightarrow(\mathrm{Zr}, \mathrm{U}) \mathrm{SiO}_{4}$ (zircon) $+\mathrm{ZrO}_{2}$ with $\mathrm{U}$.

In comparison with the brown "lava", the black "lava" are sharply depleted in uranium phase inclusions. However, the concentration of uranium dissolved in the glass-like matrix of the black "lava" is 1.5 times higher, than in the silicate matrix of the brown "lava" (Table 1). This was caused by the dissolution of the most dispersed solid inclusions of the $\mathrm{UO}_{\mathrm{x}}$, and $\mathrm{UO}_{\mathrm{x}}$ with $\mathrm{Zr}$, during the black "lava" spreading-out, as well as by the slow cooling of this type of "lava".

The brown "lava" matrix has a large number of solid inclusions of uranium phases. It is in these solid inclusions of the $\mathrm{UO}_{\mathrm{x}}$ with $\mathrm{Zr}$ the main part of uranium present in the brown "lava". These inclusions of own brown color are the reason for the coloring of this type of "lava". The morphology of the $\mathrm{UO}_{\mathrm{x}}+\mathrm{Zr}$ phase inclusions is very diverse. There are particles with a fused morphology, cubic and cubo-octahedric crystals, as well as dendrites. These inclusions of $\mathrm{UO}_{\mathrm{x}}$ with $\mathrm{Zr}$ have, presumably, different origins:

1. Particles with fused morphology: They are relicts of solidified drops of the initial melt of $\mathrm{UO}_{\mathrm{x}}$ with $\mathrm{Zr}$;

2. Crystalline inclusions: They are products of the recrystallization of the $\mathrm{UO}_{\mathrm{x}}$ with $\mathrm{Zr}$ melt; 
3. Fine inclusions of 1-3 microns in size inside crystals of high-uranium zircon: They are the products of reaction between the $\mathrm{Zr}-\mathrm{U}-\mathrm{O}$ phase and silicate melt: $\mathrm{Zr}-\mathrm{U}-\mathrm{O}+\mathrm{SiO}_{2} \rightarrow$ $(\mathrm{Zr}, \mathrm{U}) \mathrm{SiO}_{4}$ (zircon) $+\mathrm{UO}_{\mathrm{x}}$ with $\mathrm{Zr}$;

4. Dendrite-like particles: They are products of recrystallization of part of the uranium initially dissolved in silicate melt in the course of the "lava" cooling.

Results of X-ray diffraction analysis (XRD) show that the structure of the main part of inclusions of the phase $\mathrm{UO}_{\mathrm{X}}$ with $\mathrm{Zr}$ corresponds to the $\mathrm{U}_{4} \mathrm{O}_{9}$. Inclusions of the $\mathrm{Zr}-\mathrm{U}-\mathrm{O}$ phase found in the brown "lava" and the "porous ceramics" are nearly amorphous to X-ray diffraction analysis with individual diffraction peaks of monoclinic zirconia phase, $\mathrm{ZrO}_{2}$. This indirectly confirms the rapid solidification of this type of "lava". It is important to note that own inclusions of $\mathrm{ZrO}_{2}$ are not typical for the matrices of Chemobyl "lava". We have found single grains of $\mathrm{ZrO}_{2}$ only in "porous ceramic". The assumption of a possible dissolution of $\mathrm{ZrO}_{2}$ in the silicate melt has not been corroborated experimentally. A simulation of the process of "lava" formation, carried out under laboratory conditions, showed that at $1600^{\circ} \mathrm{C}$ the penetration of fragments of oxidized zircaloy cans by the silicate melt was not accompanied by dissolution of $\mathrm{ZrO}_{2}$ by the melt. The zirconium admixture in the silicate melt was obtained by interaction between an artificially synthesized $\mathrm{Zr}-\mathrm{U}-\mathrm{O}$ composition and concrete at $1600^{\circ} \mathrm{C}$.

Table 2. The composition of different types of uranium-zirconium-bearing oxide phases in the Chemobyl "lava" (wt. \%).

\begin{tabular}{|c|c|c|c|c|}
\hline Types of inclusions & $\begin{array}{l}\text { Types of } \\
\text { "lava" }\end{array}$ & $\mathbf{U}$ & $\mathbf{Z r}$ & Interpretation \\
\hline $\begin{array}{l}\text { The inclusion of irregular morphology in the } \\
\text { matrix }\end{array}$ & black & 78.3 & 2.7 & $\mathrm{UO}_{\mathrm{x}}$ with $\mathrm{Zr}$ \\
\hline $\begin{array}{l}\text { The inclusion of irregular morphology inside } \\
\text { the crystal of high-uranium zircon }\end{array}$ & black & 84.9 . & 2.5 & $\mathrm{UO}_{\mathrm{x}}$ with $\mathrm{Zr}$ \\
\hline Isolated crystal of cubic form in the matrix & black & 83.3 & 3.0 & $\mathrm{UO}_{\mathrm{x}}$ with $\mathrm{Zr}$ \\
\hline Stellate crystal in the matrix & brown & 82.6 & 4.7 & $\mathrm{UO}_{\mathrm{x}}$ with $\mathrm{Zr}$ \\
\hline $\begin{array}{l}\text { The aggregate of inclusions of irregular } \\
\text { morphology in the matrix }\end{array}$ & $\begin{array}{l}\text { Porous } \\
\text { ceramic }\end{array}$ & $\begin{array}{l}80.3 \\
18.3\end{array}$ & $\begin{array}{l}7.1 \\
65.5\end{array}$ & $\begin{array}{l}\mathrm{UO}_{\mathrm{x}} \text { with } \mathrm{Zr} \\
\mathrm{Zr}-\mathrm{U}-\mathrm{O}\end{array}$ \\
\hline $\begin{array}{l}\text { The aggregate of inclusions of irregular } \\
\text { morphology in the matrix }\end{array}$ & brown & $\begin{array}{l}80.4 \\
18.1\end{array}$ & $\begin{array}{l}6.1 \\
66.0\end{array}$ & $\begin{array}{l}\mathrm{UO}_{\mathrm{x}} \text { with } \mathrm{Zr} \\
\mathrm{Zr}-\mathrm{U}-\mathrm{O}\end{array}$ \\
\hline $\begin{array}{l}\text { The inclusion of irregular morphology inside } \\
\text { the crystal of high-uranium zircon }\end{array}$ & black & 5.8 & 75.0 & $\mathrm{ZrO}_{\mathrm{x}}$ with $\mathrm{U}$ \\
\hline $\begin{array}{l}\text { The porous inclusion with microblock } \\
\text { structure in the matrix }\end{array}$ & brown & 86.0 & - & $\mathrm{UO}_{2-\mathrm{x}}$ \\
\hline
\end{tabular}

\section{CONCLUSIONS}

The investigations described provide an understanding of the behaviour of nuclear fuel in the first days of the Chernobyl accident. An integrated scheme of physico-chemical transformation of the starting uranium fuel is presented (Fig. 4 ). As a result of the accident the 
formation of new solid uranium phases took place: $\mathrm{UOx}$ with $\mathrm{Zr}, \mathrm{Zr}-\mathrm{U}-\mathrm{O}$, uranium-containing glass, $(\mathrm{Zr}, \mathrm{U}) \mathrm{SiO}_{4}$ - zircon, $\mathrm{ZrO}_{2}$ with $\mathrm{U}$ and $\mathrm{Zr}$ metall with uranium admixture.

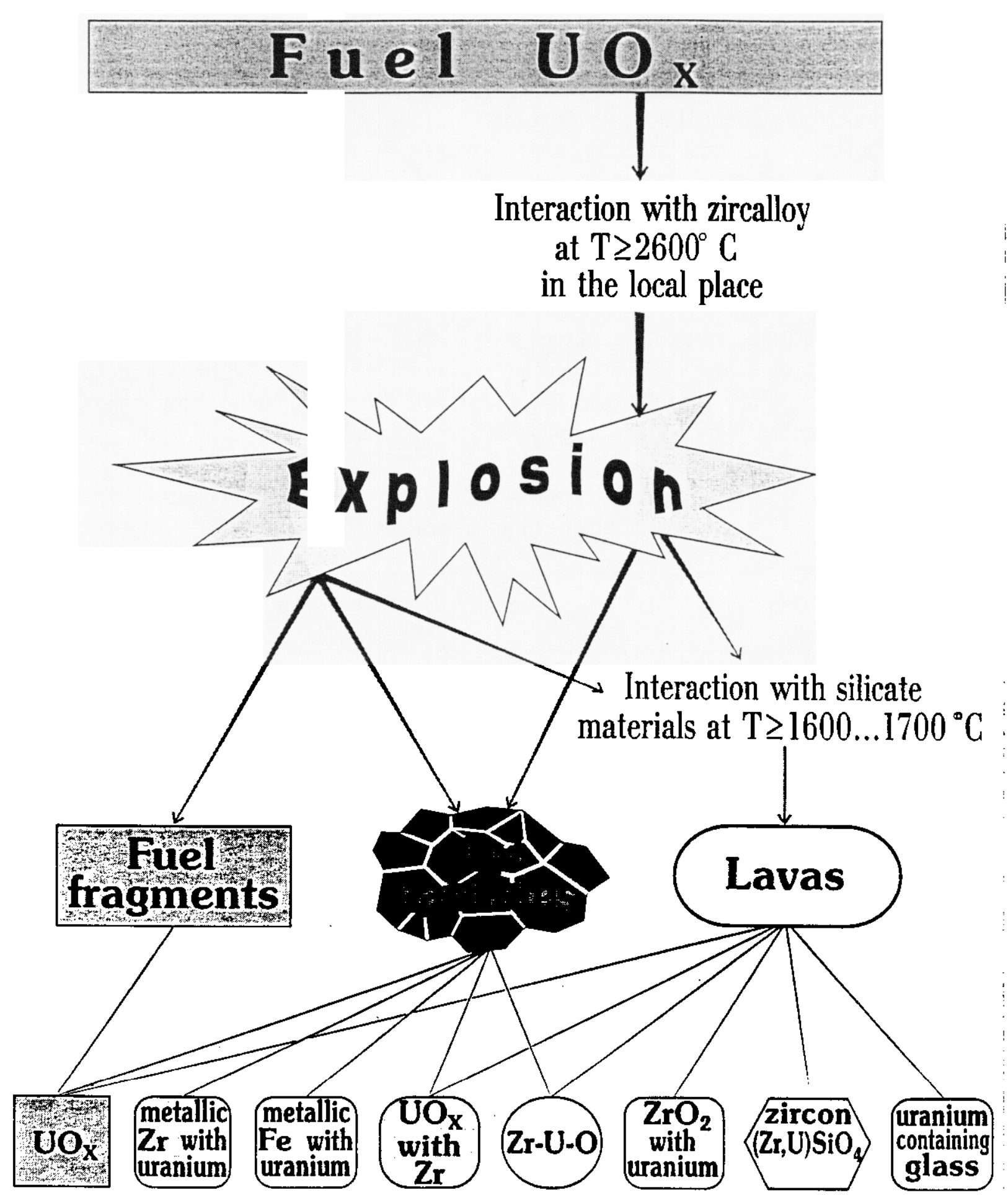

Fig. 4. Physico-chemical transformation of nuclear fuel during Chernobyl accident. 
In our opinion, the most important conclusion is that an essential chemical change of the fuel took place even before the moment of Chernobyl explosion. The transformation of the fuel began in the volume of nuclear reactor at the level " $\mathrm{UO}_{2}$ - Zircaloy". It allows us to use our results to simulate of major accidents on various types of nuclear reactors. It is important to compare our results with the data of Three Mile Island accident.

The main unanswered question concerns the amount of fuel involved in the interaction with zircaloy cladding at the early stage of the accident. The value of instantaneous energy release during the accident, based on determining the activity ratio of Xe-133 and $\mathrm{Xe}-133 \mathrm{~m}$ in air, allows us to assess the proportion of overheated fuel as being $0.01-0.1 \%$ of its total mass [31]. More precise assessments, however, may be obtained by determining the proportion of "hot" particles with zirconium-containing matrices in the form $\mathrm{UO}_{\mathrm{x}}$ with $\mathrm{Zr}, \mathrm{Zr}-\mathrm{U}-\mathrm{O}$, out of the total amount of fuel particles.

Note, that the high-temperature event in the fuel prior to the explosion was quite short, less than first seconds, because most of the "hot" particles with matrices of $\mathrm{UO}_{\mathrm{x}}$ with $\mathrm{Zr}$ and $\mathrm{Zr}-\mathrm{U}-\mathrm{O}$ retained their essential compositions of light-volatile radionuclides, for example, Cs-134 and Cs137. An experimental simulation of the dynamics of radionuclides release from the $\mathrm{Zr}-\mathrm{U}-\mathrm{O}$ melt may be used to evaluate the duration of the accident's initial phase. Thus, our work is not complete. In some points it contradicts the already published versions [32] of the Chernobyl accident scenario, proposing the possibility of interaction between fuel and zircaloy cladding after explosion. Therefore, these investigations must continue, as they are an essential part of safety assessment of nuclear reactors and their behavior during melt-down events.

\section{ACKNOWLEDGMENTS}

The authors are very grateful to R.C. Ewing and W. Lutze of the University of New Mexico for help in the preparation of this review and to N. Rutchkovski of IPSN and A. P. Zavragzin of Radium Institute for the translation of this article into English. The collaboration between University of New Mexico and V.G. Khlopin Radium Institute is supported by the NATO International Scientific Exchange Program.

\section{REFERENCES}

1. At. Energ. 61, p. 301 (1986) (in Russian).

2. Nuclear News 29, p. 59 (1986).

3. Publication series on safety N 75-INSAG-1, Proceedings of Conference on Studies of Causes and Consequences of Chemobyl Accident. IAEA, STI/PUB/740, ISB N-92-0423088-6, Wien (1988).

4. L. Devell, H. Tovedal, U. Bergström, A. Appelgren, J. Chyssler, L. Andersson, Nature 321, (1986) p. 192

5. P. Schubert, U. Behrend, Radiochimica Acta 41, p. 149-155 (1987)

6. S.A. Bogatov, A.A. Borovoy, Yu.V. Dubasov, V.V. Lomonosov About forms of the fuel release in the accident at the Chernobyl NPP. Preprint IAE-4952, Moscow (1989) (in Russian).

7. A.A. Borovoy Inside and outside the "Sarcofagus". Preprint KE IAE, Chernobyl (1990). (in Russian).

8. S.A. Bogatov, A.A. Borovoy, V.I. Dvoretskiy, L.A. Elesin, N.V. Isaev, V.V. Lomonosov, L.I. Lebedeva, I.V. Matveev, V.N. Nikitin, L.A. Obukhova, I.A. Semin, Yu.N. Simirskiy, 
An investigation of the most radiologically hazardous nuclides in various forms of the fuel release of the Chernobyl accident. Preprint IAE-5022/3, Moscow (1990). (in Russian).

9. E. Piasecki, P. Jaracz, S. Mirowski, J. of Radioanalytical and Nuclear Chemistry, Articles 141, 2, p. 221-259 (1990)

10. S.A. Bogatov, A.A. Borovoy Preprint IAE-5344/3, Moscow (1991). (in Russian).

11. E.B. Anderson, B.E. Burakov, E.M. Pazukhin, Radiokhimia 5 (1992) p. 139 (in Russian).

12. L.M. Khitrov, V.O. Cherkezian, O.V. Rumiantsev, Geochemistry 7 (1993), p. 963. (in Russian).

13. E.P. Petriaev, S.L. Leynova, G.A. Sokolik, E.M. Danil'chenko, V.V. Duksina, Geochemistry 7, (1993), p. 930 (in Russian).

14. B.E. Burakov, E.B. Anderson, B.Ya. Galkin, E.M. Pazukhin, S.I. Shabalev, Radiochimica Acta 65, p. 199-202 (1994).

15. A.A. Borovoy, B.Ya. Galkin, A.P. Krinitsyn, V.M. Markushev, E.M. Pazukhin, A.N. Kheruvimov, K.P. Checherov, New-formed products of the interaction of fuel with structural materials of the 4th unit of the Chemobyl NPP, Radiochem. 32, p.103-113 (1990).

16. A.A. Borovoy, G.D. Ibraimov, S.S. Ogorodnik, V.D. Popov, K.P. Checherov The state of the ChNPP 4th unit and nuclear fuel being in it (by results of investigations of 1988-1989). Preprint KE IAE. Chernobyl (1990). (in Russian).

17. A.N. Kiselev, A.Yu. Nenagliadov, A.I. Surin, K.P. Checherov, Preprint IAE-5533/3, Moscow (1992). (in Russian).

18. A.S. Krivokhatskiy, V.G. Savonenkov Classification of radioactive man-made products from debris of 4th Unit of the Chernobyl nuclear power plant. Preprint RI-216, Ts'NII atominform, (1990). (in Russian).

19. E.B. Anderson, B.E. Burakov, E.M. Pazukhin Did the fuel of the 4th Unit of Chernobyl NPP melt? Radiochem. 5 (1992). (in Russian).

20. E.B. Anderson, B.E. Burakov, E.M. Pazukhin High uranium zircon ( $\mathrm{Zr}, \mathrm{U}) \mathrm{SiO} 4$ from "Chernobyl lavas". Radiochimica Acta 60, p. 149 (1993).

21. B.E. Burakov in Proceedings of international conference SAFEWASTE'93 2, (1318/06/1993, Avignon, (FRANCE)) p. 19-28.

22. M.Trotabas, J-Y. Blanc, B. Burakov, E. Anderson, J. Duco Examination of Chernobyl samples, impact on the accident scenario understanding. Report IPSN/93/02 (1993), DMT/92/309, RI -1-63/92 (1993).

23. Report of the US Department of Energy's Team analyses of the Chernobyl atomic energy station accident sequence. DOE/NE-0076, DE 87 003614, Washington (1986).

24. N.I. Gol'tsova, N.I. Abaturov in Eurochernobyl-2. Materials of the international conference. (Kiev, 1992), p. 155 (in Russian).

25. A. Skokan, Proc. on Thermal Nuclear Reactor Safety, KfK-3880/2, p. 1035-1041. (1984)

26. Y. Kanno, J. Mater. Sci., 24 (1989) p. 2415

27. P. Pena, S. de Aza, J. of Mater. Sci., 19 (1984) p. 135-142.

28. M.A. O'Donoghue J. of Gemology 3, vol. XV, , (1976) p. 119-124.

29. B.M. Wanklyn, J. Cryst. Growth 37, 1 (1977) p. 51-56

30. Synthesis of minerals. v. 2, Moscow: "Nedra", 1987. (in Russian).

31. S.A. Pakhomov, K.S. Krivochatskiy, I.L. Sokolov, Radiochem. 6, (1991), p.125. (in Russian)

32. E.M. Pazukhin, Radiochem. 36, iss. 2, (1994), p. 97-142. (in Russian). 


\section{Expertise at Argonne National Laboratory for Glass Formulation and Characterization}




\section{Development of Expertise}

- $\quad$ Started ca 1980

- Early involvement in high-level waste glass

- $\quad$ testing or repository behavior

- characterization

- Developed testing techniques

- Developed characterization

- Glass formulation

- glass ceramics

- $\quad$ alkali-tin-silicate

- $\quad$ hazardous waste (MAWS concept)

Chemical Technology Division 


\section{Tests Developed}

Drip

Vapor hydration

Accelerated dissolution

Chemical Technology Division 


\section{Tests Developed}

Drip

Test Vessel

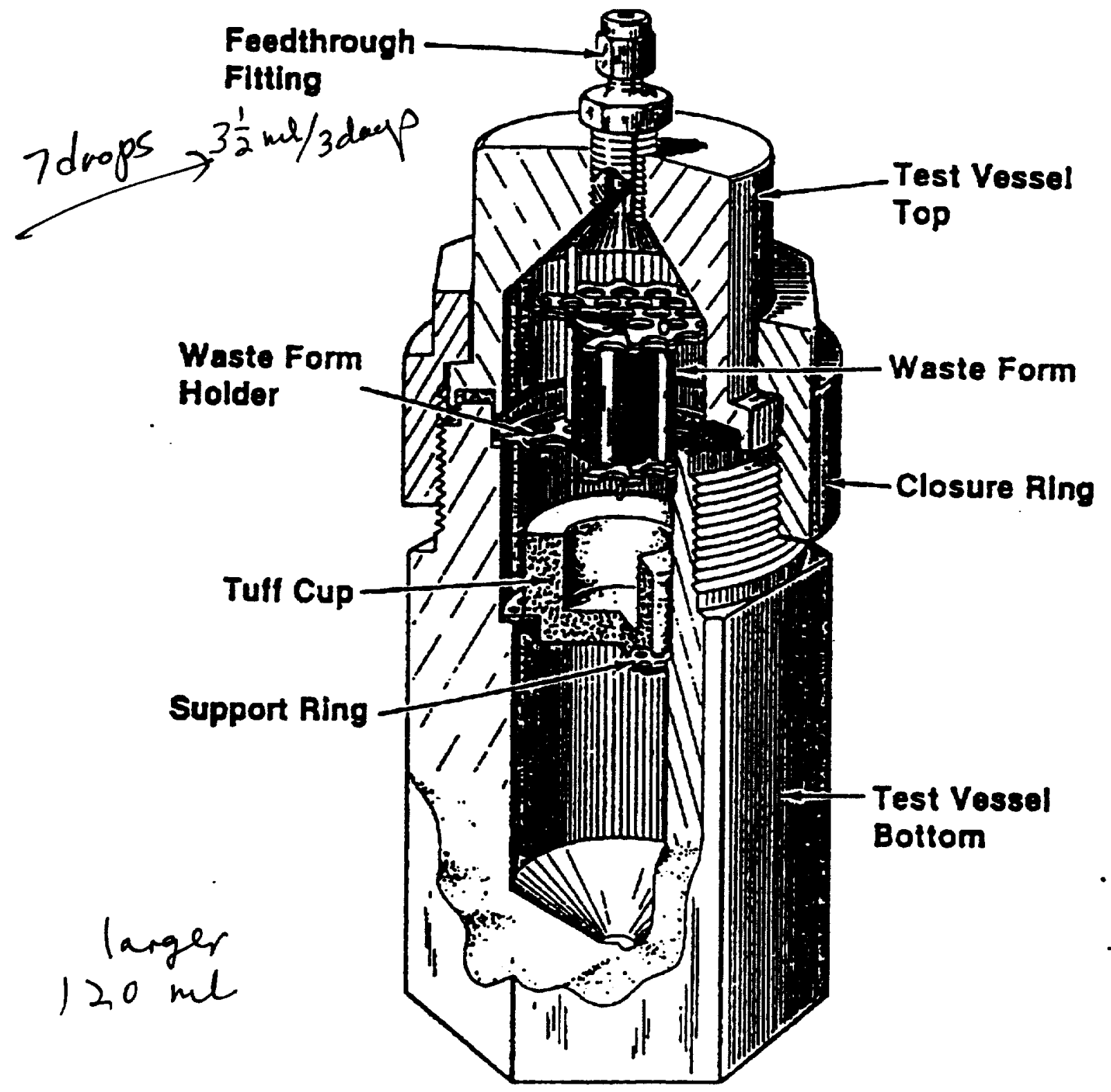

\section{Chemical Technology Division}




\section{Characterization}

- $\quad$ SEM

- $\quad$ AEM

- ultramicrotome

- $\quad$ electron diffraction

- $\quad$ electron energy loss spectroscopy

Chemical Technology Division 


\section{LaBS Glass}

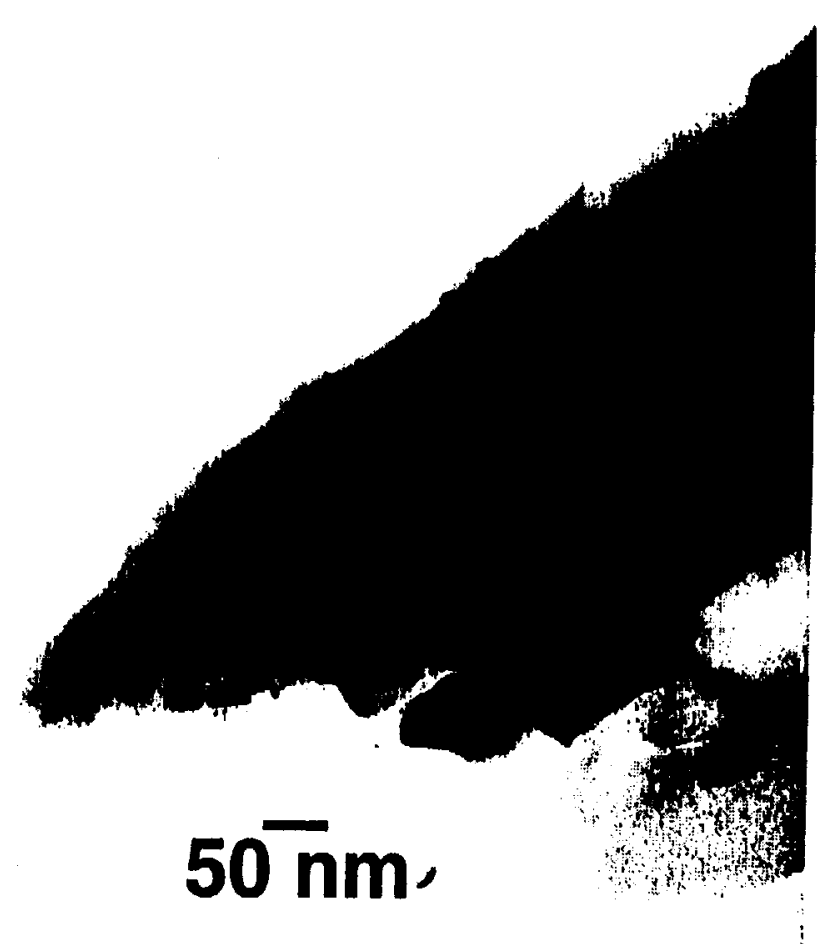

Chemical Technology Division 


\section{Formulation Examples}

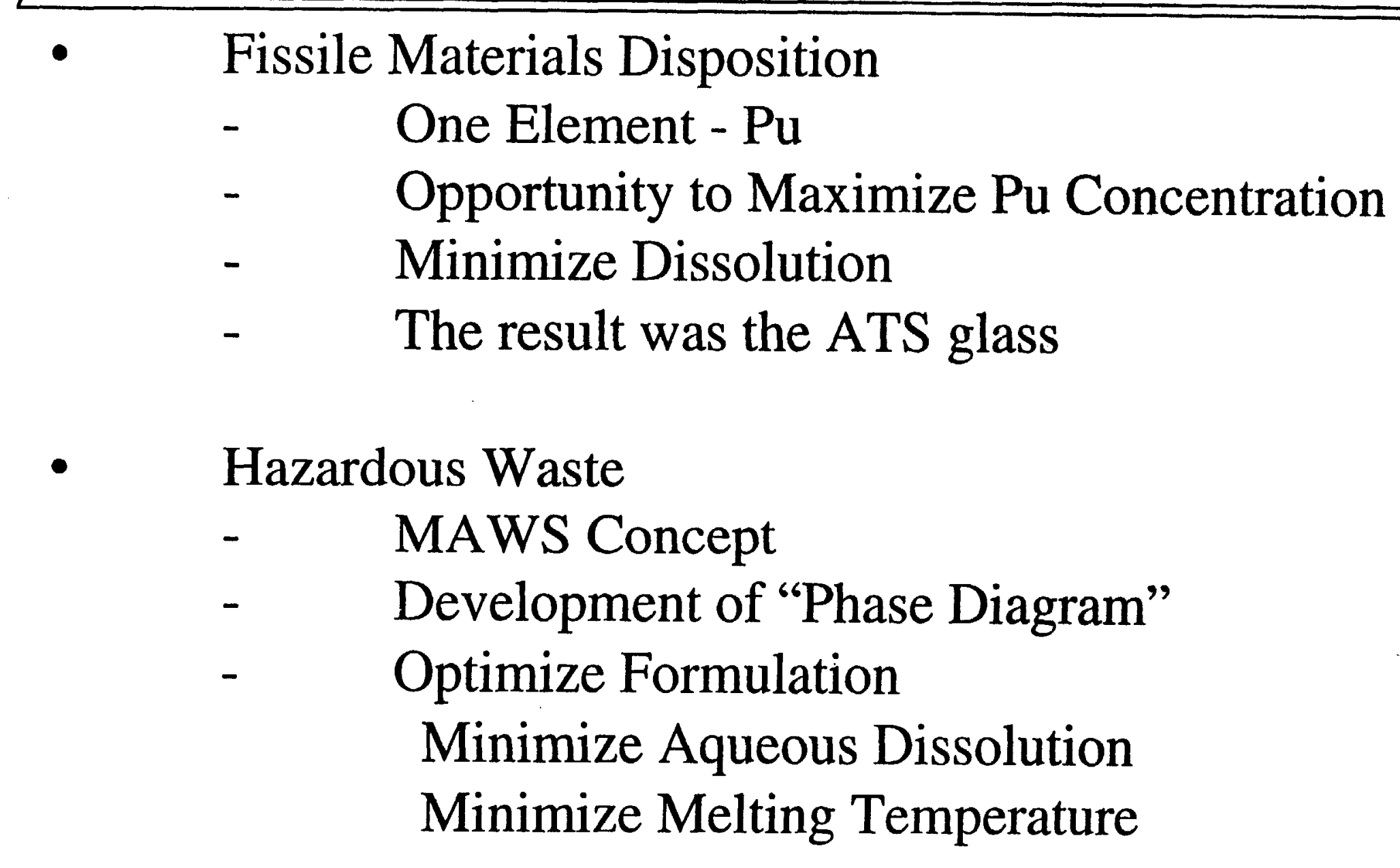

Chemical Technology Division 


\section{LaBS Glass}

- 14 Day VHT Sample

- TEM results

- Alteration layer: Pu-rare earthsilicates \& Alsilicates

Chemical Technology Division

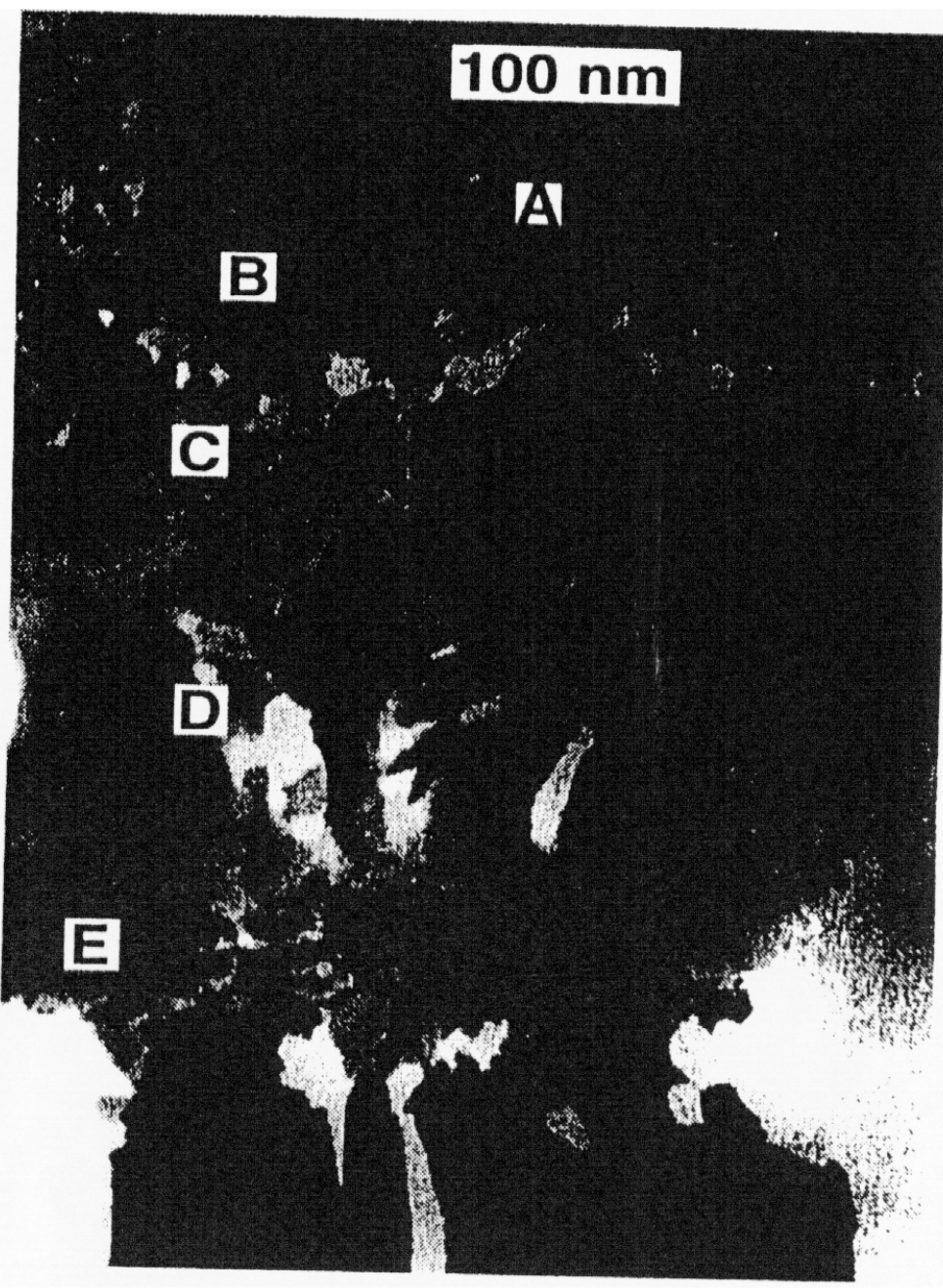




\section{Corrosion Testing}

- Independent lab testing at ANL

- Perform same test matrix for glass and ceramic forms

- Tests include

- short- and long-term tests

- solution analyses and solids characterization

Chemical Technology Division 


\section{Overview of Tests}

\begin{tabular}{|c|c|c|c|c|}
\hline Test & Form & $\begin{array}{c}\text { Temperature } \\
\left({ }^{\circ} \mathrm{C}\right)\end{array}$ & $S / V\left(m^{-1}\right)$ & Purpose \\
\hline$M C C-1$ & Monolith & 90 & 10 & $\begin{array}{l}\text { To measure the } \\
\text { dissolution at low S/V; } \\
\text { comparison of materials }\end{array}$ \\
\hline $\begin{array}{l}\text { PCT } \\
(A \& \text { \&) } \\
/ \\
\text { dayp }\end{array}$ & Powder & 90 & $\begin{array}{r}2,000 \\
20,000\end{array}$ & $\begin{array}{l}\text { Accelerated reactions by } \\
\text { use of } S / V\end{array}$ \\
\hline $\begin{array}{l}\text { VHT } \\
\text { por } \\
\text { gdrativ } \\
\text { Test }\end{array}$ & Monolith & 200 & $\mathrm{n} / \mathrm{a}$ & $\begin{array}{l}\text { Determine alteration } \\
\text { phases that will occur at } \\
\text { long times without flow. }\end{array}$ \\
\hline
\end{tabular}

Chemical Technology Division 


\section{MCC-1 Test}

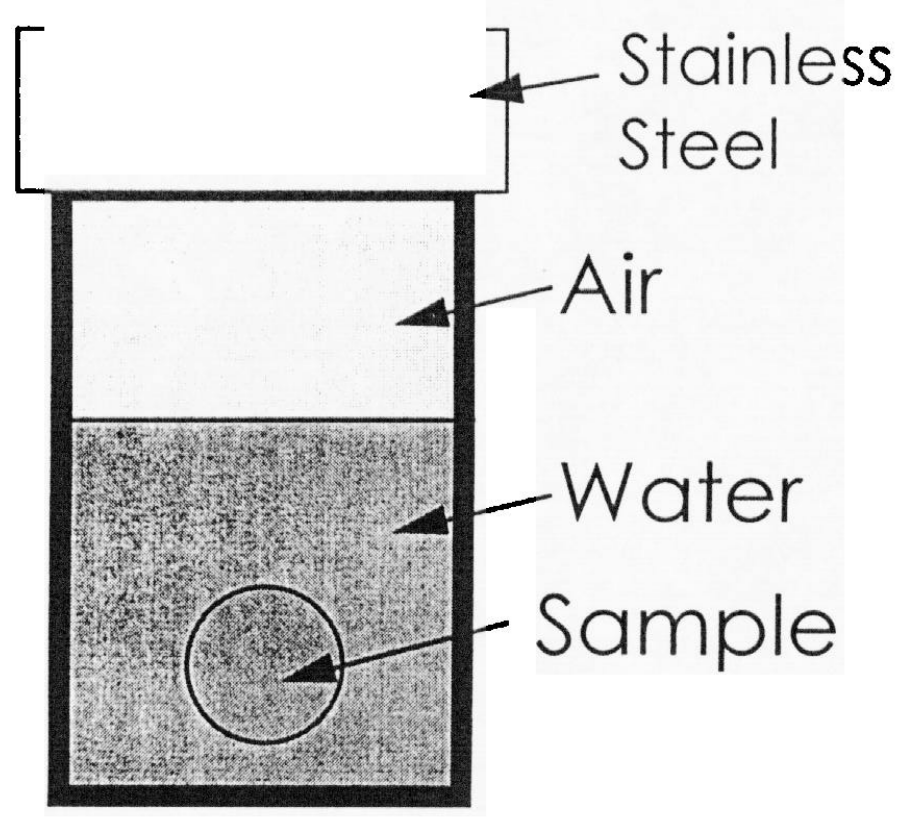

- Static batch test with monolithic sample

- Low solution concentrations

- Standardized in ASTM C1220-92

- Typically 3 day duration 


\section{Product Consistency Test (PCT)}

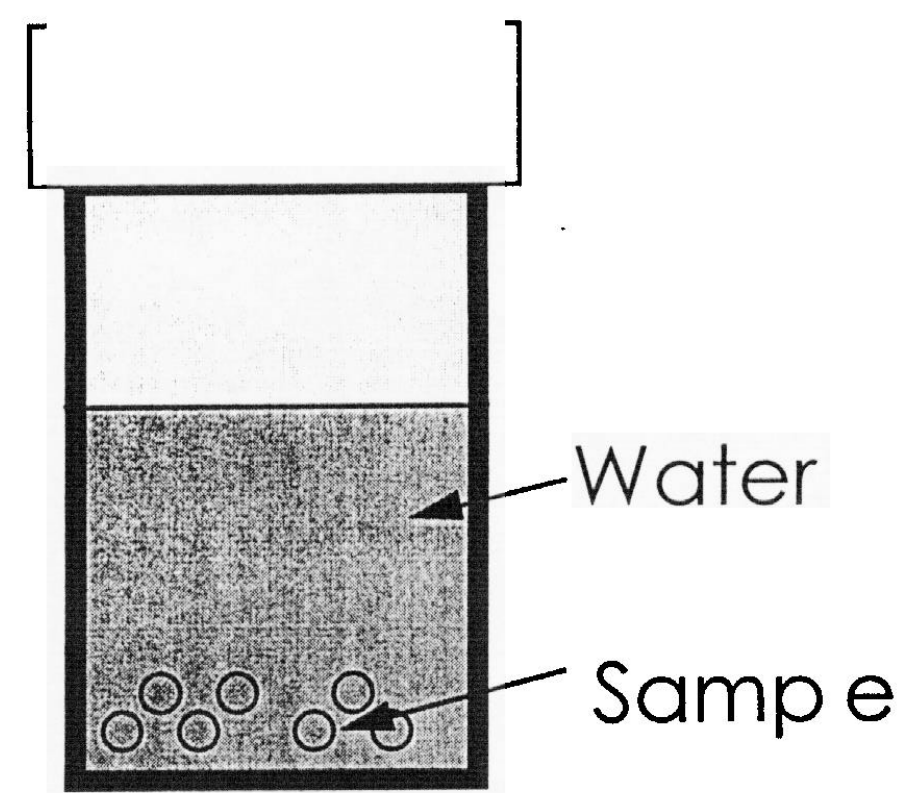

- Static batch test

- Crushed glass sample

- Accelerate reaction with high $\mathrm{S} / \mathrm{V}$

- Standardized in ASTM C1285-94

- A 7-day test is used at DOE facilities

Chemical Technoloav Division 


\section{Vapor Hydration Test (VHT)}

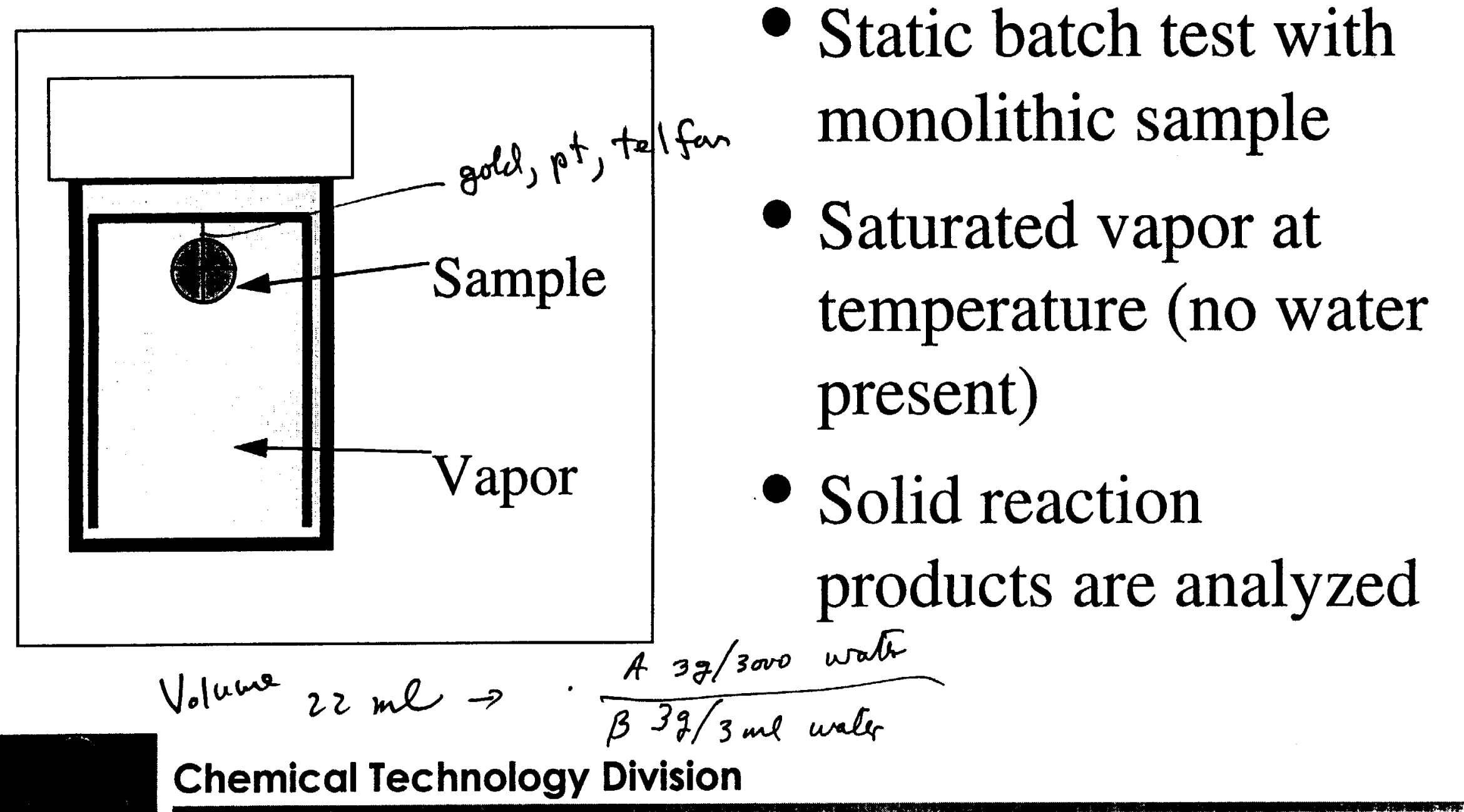




\section{Sample Receipt}

- Ceramic

- two shipments of ceramic received from LLNL, one in 1996 and the second in 1997

- LaBS Glass

- one shipment of glass received from PNNL in September, 1996

- glass was a product of some test melts at PNNL

- several batches of glass were melted together and shipped to ANL for testing

Chemical Technology Division 


\section{Glass Sample Description}

- Sample received from PNNL

- sample as received consisted of quenched pieces and an annealed bar

- homogeneous; no undissolved $\mathrm{PuO}_{2}$

$+10.5 \mathrm{wt} \% \mathrm{Pu}\left(11.9 \mathrm{wt} \% \mathrm{PuO}_{2}\right)$ by analysis

- monoliths prepared from bar

- remainder of bar combined with quenched pieces and crushed for PCT

Chemical Technology Division 


\section{Normalized Release}

$$
N L(i)=\frac{\left(C_{i}-C_{i}^{0}\right)}{S / V \bullet f_{i}}
$$

$\mathrm{NL}(\mathrm{i})=$ normalized release of element $\mathrm{i}$ in $\mathrm{g} / \mathrm{m}^{2}$

$C_{i}=$ concentration of element $i$ in leachate, $g / \mathrm{m}^{3}$

$C_{i}^{\circ}=$ initial concentration of element $\mathrm{i}$ in $\mathrm{g} / \mathrm{m}^{3}$

$\mathrm{S}=$ surface area of the material in $\mathrm{m}^{2}$

$\mathrm{V}=$ volume of the material in $\mathrm{m}^{3}$

$f_{i}=$ weight fraction of element $i$ in the test material

Chemical Technology Division 


\section{EA Glass VHT Sample}

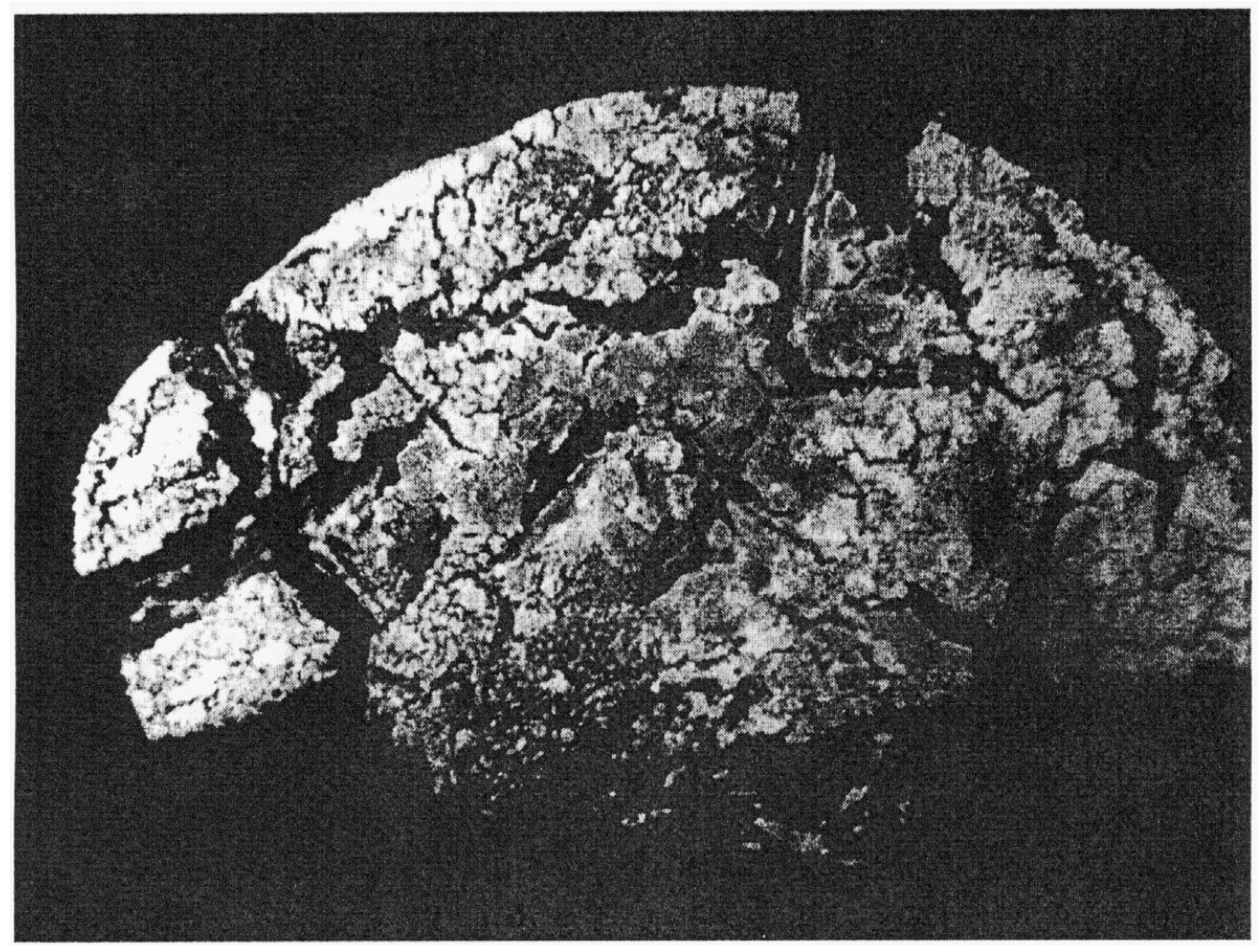

\section{EA Glass}

VHT Conditions

- $200^{\circ} \mathrm{C}$

- 1 day

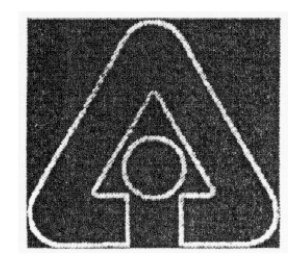

Chemical Technology Division 


\section{Status: Glass Testing}

- LaBS Glass corrosion with DIW

- Completed corrosion tests

+ MCC-1 (3 day)

+ PCT-A (7 day)

+ VHT (7 - 56 days)

- PCT-B have been underway for 280 days

+ (28 - 182 days analyzed)

Chemical Technology Division 


\section{PCTs at $20,000 \mathrm{~m}^{1}$}

Time Element [Al] $[\mathrm{B}]$ [Si] $[\mathrm{Sr}$ ] $\mathrm{Zr}$ ] [La] [Nd] [Gd] [Pu] (days)

$\begin{array}{llllllllll}(\%) & (\%) & (\%) & (\%) & (\%) & (\%) & (\%) & (\%) & (\%)\end{array}$

$\begin{array}{lllllllllll}28 & \text { Solution } & 97 & 50 & 76 & 64 & 8 & 2 & 2 & 2 & 4\end{array}$ $\begin{array}{llllllllll}\text { Strip } & 3 & 50 & 24 & 36 & 92 & 98 & 98 & 98 & 96\end{array}$

$\begin{array}{lllllllllll}98 & \text { Solution } & 93 & 48 & 64 & 16 & 24 & 1 & 1 & 1 & 1\end{array}$ $\begin{array}{llllllllll}\text { Strip } & 7 & 52 & 36 & 84 & 76 & 99 & 99 & 99 & 99\end{array}$

$\begin{array}{lllllllllll}182 & \text { Solution } & 99 & 76 & 82 & 7 & 48 & 8 & 9 & 13 & 31\end{array}$ $\begin{array}{llllllllll}\text { Strip } & 1 & 24 & 18 & 93 & 52 & 92 & 91 & 87 & 69\end{array}$

Chemical Technology Division 


\section{LaBS Test Solutions}

$\begin{array}{cccc}\text { Test } & \begin{array}{c}\text { Time } \\ \text { (days) }\end{array} & \begin{array}{c}\text { Pu in } \\ \text { Soln } \\ (\%)\end{array} & \begin{array}{c}\text { Pu in } \\ \text { Strip } \\ (\%)\end{array} \\ \text { HCC-1 } & 3 & 44.4 & 55.6 \\ \text { CT-A } & 7 & 12.3 & 87.7 \\ & & & \\ \text { CT-B } & 28 & 4.1 & 95.9 \\ & 98 & 1.4 & 98.6 \\ & 182 & 30.7 & 69.3\end{array}$

Chemical Technology Division 


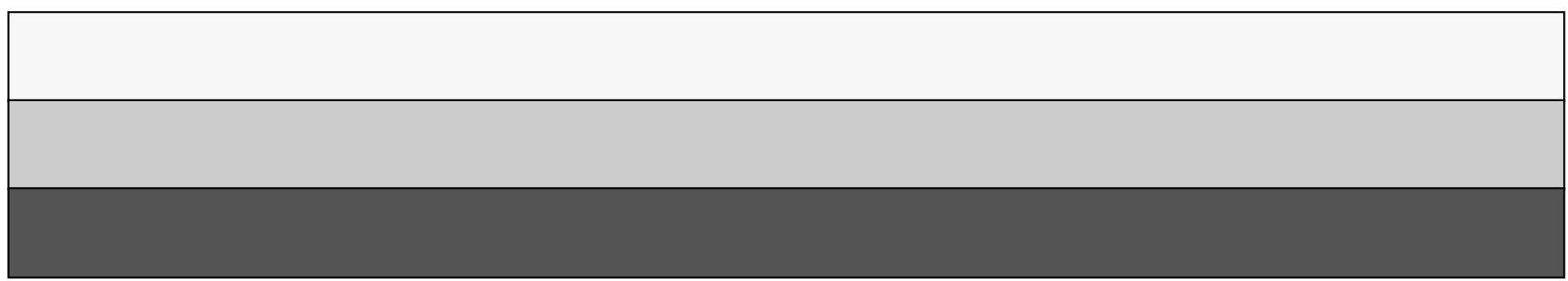

